\title{
Preliminary Modeling of Moisture Movement in the Tuff Beneath Mortandad Canyon, Los Alamos National Laboratory
}

\author{
A. M. Geddis* \\ Hyclrology Dept. \\ Univ. of Arizona. Tucson
}

5 . August, 1992

\begin{abstract}
DISCLAIMER
This report was prepared as an account of work sponsored by an agency of the United States Government. Neither the United States Government nor any agency thereof, nor any of their employees, makes any warranty, express or implied, or assumes any legal liability or responsibility for the accuracy, completeness, or usefulness of any information, apparatus, product, or process disclosed, or represents that its use would not infringe privately owned rights. Reference herein to any specific commercial product, process, or service by trade name, trademark, manufacturer, or otherwise does not necessarily constitute or imply its endorsement, recommendation, or favoring by the United States Government or any agency thereof. The views and opinions of authors expressed herein do not necessarily state or reflect those of the United States Government or any agency thereof.
\end{abstract}




\title{
Preliminary Modeling of Moisture Movement in the Tuff Beneath Mortandad Canyon, Los Alamos National Laboratory
}

\author{
A. M. Gedlis* \\ Hydrology Dept. \\ Univ. of Arizona, Tucson
}

5 August. 1992

\begin{abstract}
An area of upper/middle Mortandad Canyon on the Los Mlamos National Laboratory is modeled in cross-section. UNSAT2, a finite element model (FE.V) is used to predict moist ure movement. Hyclraulic characteristics of the tuff are described by van Genuchten parameters determined from laboratory tests on cores taken from a borchole within the cross-section. Material properties are distributed horizontal planar in space to cover the nolation domain with required initial conditions. An estimate of seepage Hux from a thin perched alluvial acuifer into the upper surface of the tuff is taken from a lumped parameter morlel. Moisture redistribution for a ponded boundary condition and a larger flux is investigated. A composite simuiation using material properties from two separate coreholes is also evaluated.
\end{abstract}

*This study was performed under appointment to the radioactive Waste Managenent Fellowship progran aduministered by Oak Ridge Associated Universities for the U.S. Department of Energy. 
1. Introduction 3

1.1. Physical System................................................. 3

2. Unsaturated Flow Model 9

2.1. UNSAT2 Flow Equation........................................11

3. Lumped Parameter Model 12

4. Computer Simulations 14

4.1. Boundary and Initial Conditions............................14

4.2. Finite Element Simulations......................................18

5. Conclusions and Discussion 30

6. References 37

7. Appendices 38

7.1. Input Files

7.2. UNSAT2 Source Code 


\section{Introduction}

Los Alamos National Laboratory (LANL) ${ }^{1}$ is located in north central New Mexiro, U.S.A. The Laboratory is situated atop the Pajarito Plateau, which is composed of Bandelier tuff. The tuff ranges in thickness from about $1000 \mathrm{ft}$. along the western edge of the plateau to less than 50 ft. eastward toward the Rio Grande canyon. For the purposes of this study the Bandelier tuff is assumed to consist of three members: the Tshirege, Tsankawi, and Otowi. These materials are described below. The ash flow, ash fall, and pumice of the Bandelier tuff was deposited by a series of volcanic eruptions 1.1 to 1.4 million years ago (Purtymun et al., 1989). The Valle Grande, a romnant expression of the caldera, is directly west of the Laboratory area.

\subsection{Physical System}

Intermittent streams have cut deep canyons in the Pajarito Plateau. These canyons concentrate surface runoff into thin stream channels in the canyon bottoms. Fig. 1 is a contour map of the portion of Mortandad Canyon containing the study area. The head of the canyon receives National Pollution Discharge Elinination System (NPDES') permitted effluents from the LANL Radioactive Liquicd Wiste Treatment Plant as well as other permitted discharges and storm-waler runoff. The discharge outfall is approximately 1.2 miles up canyon from corehole MCM 5.1 (sec Fig. 1). This offluent and natural surface runoff recharge a shallow perched alluvial aquifer. The aquifer is in a thin veneer of sediments that rest on top of the unsaturated tuff. Fig. 2 schematically depicts the relationship between alluvium and tuff in a cross-section perpendicular to the canyon axis.

The alluvium is derived from weathered tuff and consists of clay, silt, sands, and gravels of quartz, sanadine, rock fragments of tuff, pumice, latite, and rhyolite, all gencrally less than 1 -inch in diameter. The sediments west of MCO 5 are dominated by sand, transitional to a silty clay unit near MCO 6 (see Fig. 1). East

\footnotetext{
'This study was performed for EM-8, Environmental Protection Group, LANL
} 


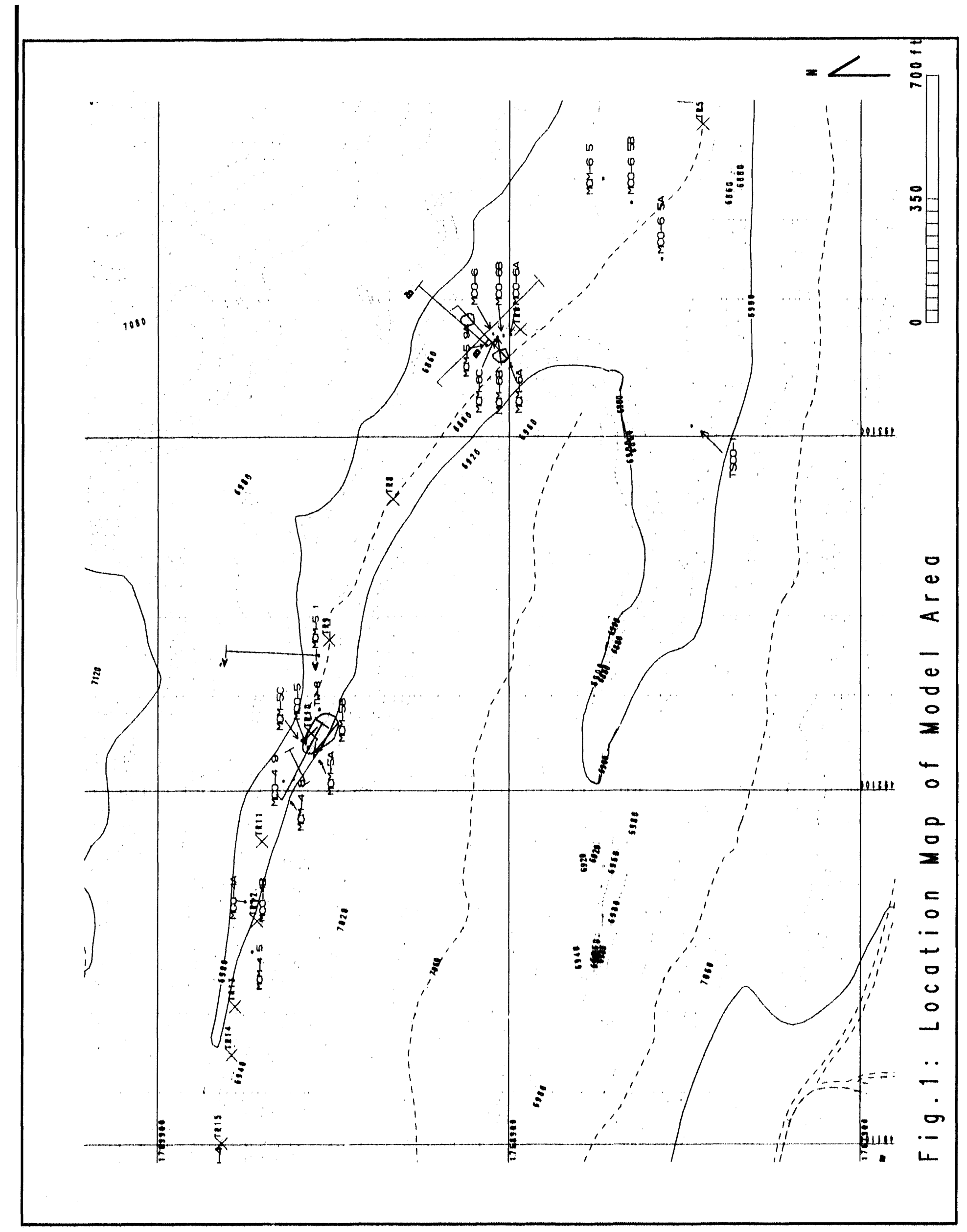




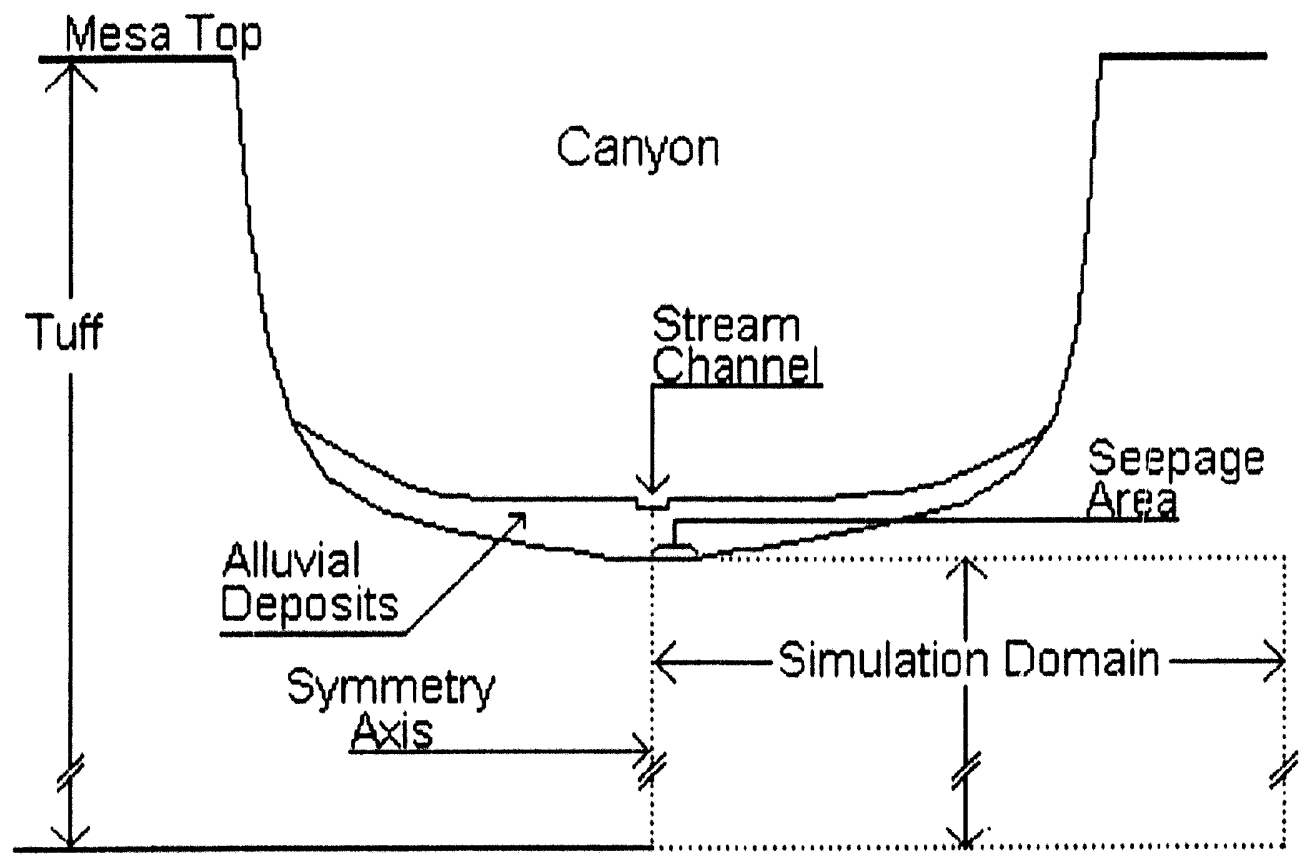

Fig. 2: Schematic cross-section of alluvium - tuff relationship. 
of MC'O 6 silty clay dominates. Tracer studies have shown the velocity of water in the sand unit to be on the order of $50 \mathrm{ft}$./day, $20 \mathrm{ft}$./day in the transitional arra, and 6-T ft./day in the silty clay area (Stoker et al., 1991). Liquid migrates through the alluvial sediments and ponds in places on top of the underlying tuff. Surface flow seldom persists past the first several thousand leet down the five mile long canyon. During the most extreme precipitation events, surface runoff has beren observed to flow more than 2 miles down the small stream channel, after which it quickly recerles. In the winter, when stream channd sedimonts remain frozon. surface llow may continue down canyon farther on average due to a decrease in chanmel permeability caused by ice (Purtymun, pers. conv.).

The canyon has been conceptually divided into three sections: Ipper Canyon. Middle ('anyon, and Lower ('anyon (Stoker et al., 1991). The hydrologic characteristics of each are slightly different. MCM 5.1 is located in the Upper Canyon which is narrow and filled with underbrush, shrubs, pine, fir, box elder, and oak trees. The alluvium thickens rastivard from less than 1 [t. at the NPIDES outliall to about 20 lt. near M(M 4.5, and nearly 30 lt. at MCM 5.1 (see Fig. 1). Stream flow in the western half of this section is peremnial due to waste water and periodic releases of industrial cffluents. The stream channel is entrenched. Major recharge to the shallow alluvial aquifer occurs in the Upper Canyon. Water loss by evapotranspiration also occurs in this section of the canyon due to the large amount of regetation and shallow extent of the sediments.

$M(1 M 5.9) \mathrm{A}$ is in the Middle ('anyon which is wider than the Upper ('anyon and characterized by thicker sediments. The sediments near MCM $5.9 \mathrm{~A}$ are $38 \mathrm{lt}$. thick. The stream channel is well defined, but surface flow is intermittent. The underbrush thins and the canyon floor is littered with pines. The Lower Canyon is wider and has thicker sediments than the Middle ('anyon. The stream channel becomes discontinuous, braiding out on the canyon floor. Fig. 3 shows cross-section $\left(\left.|B|\right|^{\prime}\right.$ ) near corehole M(M 5.9)A (see l.ig. 1) including the general location of a typical computer simmlation domain used in this study. The corehole penetrates the upper $19.1 \mathrm{lt}$. of the profile. Nine core samples were analyzed to determine pertinent hydratilic characteristics (Stokep et al., 1991). Table I is a summary of the hydranlic data for these cores, including the important van Cenuchten parameters. The sample number denotes the depth at which the core sample was taken. These locations are represented hy "pins" through the schematic corehole shown on Fig. 3. Tablo 2 is a summary of similar clata for corchole MC'dI i.l. represented by line $A A^{\prime}$ on Fig. 1. 


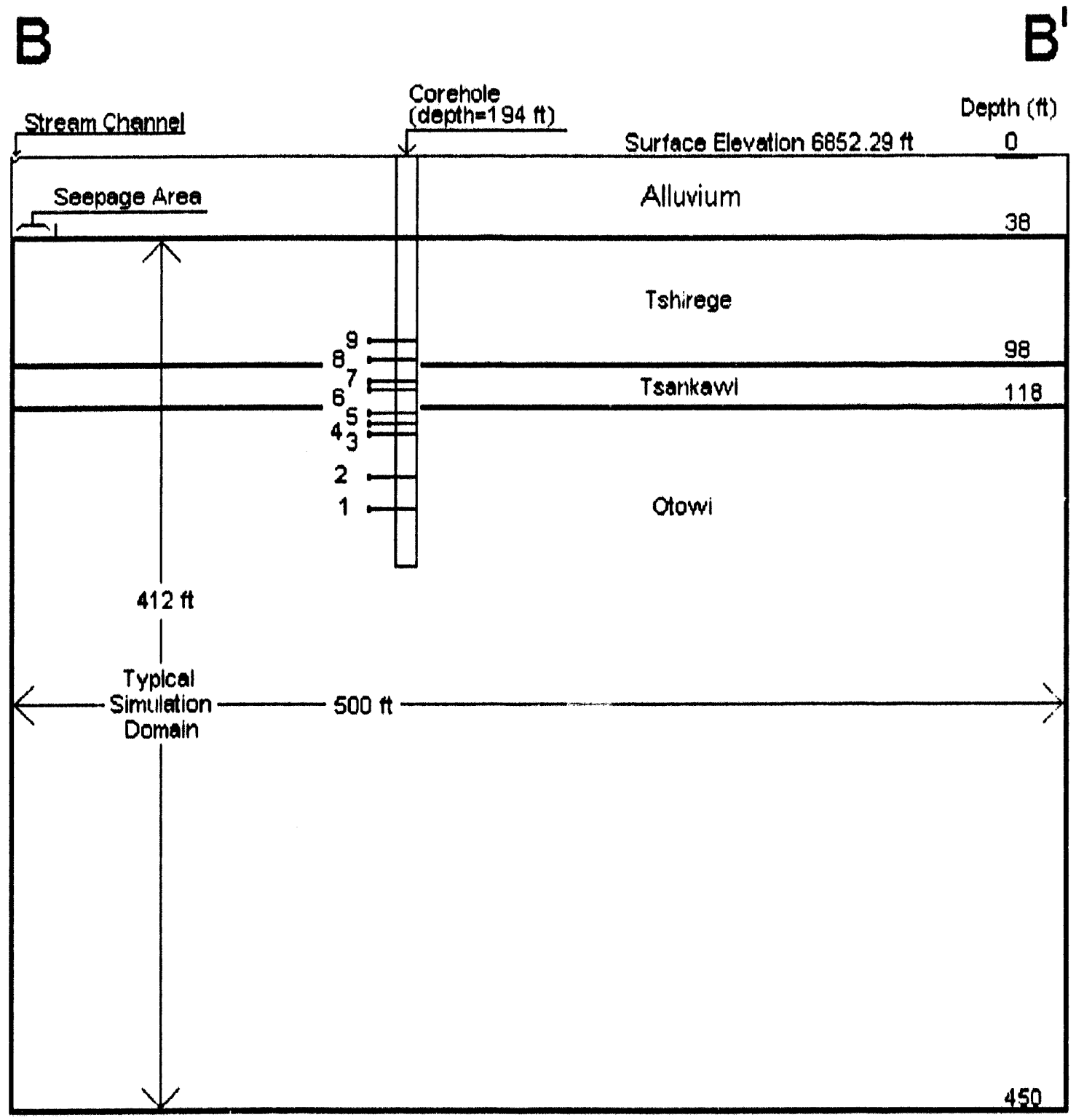

Fig. 3: Conceptual cross-section used for computer simulation domain near corehole MCM 5.9A, middle Mortandad canyon (1 inch = $100 \mathrm{fl}$, [-] = sample location). 


\begin{tabular}{|c|c|c|c|c|c|}
\hline $\begin{array}{l}\text { Sample Number } \\
\text { (('orehole MI(M 5.9A) }\end{array}$ & $\begin{array}{c}a \\
\left(c m^{-1}\right)\end{array}$ & $\bar{N}$ & $\begin{array}{c}\theta_{R} \\
\left(\frac{c m^{3} H_{2} O}{m^{3} T u L}\right)\end{array}$ & $\begin{array}{c}O_{S} \\
\left(\frac{\mathrm{cm}^{3} \mathrm{H}_{2} \mathrm{O}}{\mathrm{cm}^{3} \mathrm{TuJ}}\right)\end{array}$ & $\begin{array}{c}K^{s} \\
\left(\times 10^{-4} \frac{\mathrm{cm}}{\mathrm{sec}}\right)\end{array}$ \\
\hline$M(! M 5.9 A$ S5.5)-86.0 & 0.10 .149 & 1.34112 & .209 & .686 & 39.0 \\
\hline.$M(' M 5.9 A$ (94.5-.95.0 & $0.0+4+33$ & 1.47 .491 & .124 & .498 & 11.0 \\
\hline$* M(M 5.9 \Lambda 104.5-105.0$ & 0.00508 & 1.72981 & $.32 !$ & .537 & 20.0 \\
\hline$* M(M 5.9 \times 109.0-109.5)$ & 0.00818 & $1 .+5120$ & .198 & $.6+6$ & 13.0 \\
\hline$M((M 5.9) A \quad 119.5)-120.0$ & 0.01 .582 & 1.55108 & $.05 \%$ & .435 & T.9) \\
\hline$M(M / 5.9 N \quad 124.5-125.0$ & 0.00801 & 1.86760 & .081 & .5 .52 & 2.8 \\
\hline M('M 5.9)A I.2!).5)-130.0 & 0.005 .555 & 1.92358 & .082 & .519 & 78.0 \\
\hline$M(\mathrm{M} 5.9) \lambda 1.19 .5-150.0$ & 0.00589 & 1.7 .1058 & .094 & .538 & 17.0 \\
\hline M( $M$.5.9) 164.5$)-1(0.5 .0$ & 0.00803 & 1.689 .45 & .120 & .486 & 2.9 \\
\hline
\end{tabular}

${ }^{*}=$ Tsankawi Momber).

Table 1: Mydraulic data for cores taken from test hole M('M 5.9A.

\begin{tabular}{|c|c|c|c|c|c|}
\hline $\begin{array}{l}\text { Sample Number } \\
\text { (('orchole } \mathrm{N}(\mathrm{N} / 5.1)\end{array}$ & $\begin{array}{c}\alpha \\
\left(c m^{-1}\right) \\
\end{array}$ & $\mathrm{N}$ & $\begin{array}{c}O_{K} \\
\left(\frac{\mathrm{cm}^{3} \mathrm{H}_{2} \mathrm{O}}{\mathrm{cm} \mathrm{m}^{3} \mathrm{TuI}}\right)\end{array}$ & $\begin{array}{c}\theta_{S} \\
\left(\frac{\mathrm{cm}^{3} \mathrm{H}_{2} \mathrm{O}}{\mathrm{m} \mathrm{m}^{3} \mathrm{~T} u \mathrm{~L}}\right)\end{array}$ & $\begin{array}{c}\Pi^{\mathrm{s}} \\
\left(\times 10^{-1} \frac{\mathrm{cm}}{\mathrm{sec}}\right) \\
\end{array}$ \\
\hline $.1(M 5.1 \quad 43 .(0-4.3 .5)$ & 0.00104 & $1.77: 361$ & $.08 !$ & .521 & 2.0 \\
\hline$M(' .15 .153-54$ ('HEM & 0.00873 & 1.88477 & .168 & .454 & 1.5 \\
\hline$M(\mathrm{M} \mathrm{5.1.57.5-58.0}$ & 0.00972 & 1.667 .46 & .061 & .520 & 1.8 \\
\hline$M(1 M 5.1 \quad(03)-6.1$ ('HEM & 0.01710 & 1.11385 & .089 & $.5: 3: 3$ & 1.3 \\
\hline$M(' M 5.1(67.0)-67.5)$ & 0.01016 & 1.55 .130 & .049 & .520 & 1.1 \\
\hline$M(' M .5 .172 .0-72.5)$ & 0.01178 & 1.19131 & .040 & .515 & 1.1 \\
\hline $.1(1.5 .18 .2 .0-82.5$ & 0.010 .59 & 1.591 .333 & 20 & .589 & 1.2 \\
\hline$M(' M 5.1 \leqslant 7.0-8 T .5$ & 0.00915 & 1.51023 & .049 & .512 & 1.1 \\
\hline$M(' M 5.1 ! 9: 2.5)-9) 3.0$ & $0.0029)$ & 1.67110 & .102 & .472 & 0.17 \\
\hline$* M(1 M 5.1 \quad 9.1 .5-(95.0$ & $0.01: 369$ & 1.50196 & .387 & .656 & 6.8 \\
\hline$* M(' M \quad 5.197 .0-97.5)$ & 0.00073 & 1.599926 & .107 & .155 & $0 . i s$ \\
\hline *Ml('M 5.1 107.0-107.5 & 0.02968 & 1.18191 & .150 & .178 & 13.0 \\
\hline
\end{tabular}

$1^{*}=$ T'sankawi M(embor).

Table 2: Hyclraulic data for cores taken from test hole M(M 5.l. 
A brice description of the unsaturated Bandelier Tulf bencath the saturated allurial sediments in the canyon bot tom is presented in clescending order:

- T'shirege Member: I'nit IA Tuff is non wolded to moderately welded, light glay in color, consisting of quartz and sanadine crystals and crystal liagments, rock lragments of pmonice, latite. and rhyolite in a matrix of gray ash. It is weathered gray, buff, or light to dark brown in places. 'l'he pumice and ash matrix is typically weathered to clay.

- Tsankawi Member: Thin lenses of silt, sand, and glavels, consisting of pumice. quartz. and sanadine crystals, and rock liagments of latite and rhyolite ranging in color from gray to dark brown represent erosion and aleposition at the top of a massive ash flow. Ash and some pumice is weathered to clay.

- Otowi Member: Massive non-woleled to moderately welded tulf consisting of fuartz and sanadine crystals and crystal fiagments. mumeroms pumine lragmonls ip 10 2-inches in length. lock fragments ol latite and rhyolite in all ash matrix. Tulf is gray to dark brown in color when weathered. ash matrix and some pumice is weallhered to silts and clay.

Several humdred feet bolow these three units lie the (illaje Member, a light tan to light gray pumice. a romglomerate unit, and a basalt layedr. The regional water table is approximately (i) beet below the base of the simulation domain.

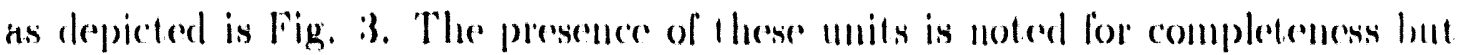
they are not included in the modeling effort as no hy draulic data exists for them. Material properties for the Otowi mint are assumed to exist to the base of the simmlation domain.

\section{Unsaturated Flow Model}

The compulater model used to describe moisture movement in the tulf is IISS.IT"2

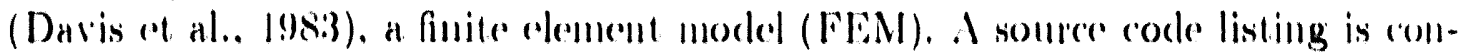
tained in the appendices. The basic two-dimensional differential equation solved by this model. discregarding storage effects as a result of tuff compressibility or any expansion of water, and any sonress or sinks in the flow domain is: 


$$
\left((h) \frac{\partial h}{\partial t}=\frac{\partial}{\partial x}\left[\kappa(h) \frac{\partial h}{\partial x}\right]+\frac{\partial}{\partial z}\left[\kappa(h) \frac{\partial h}{\partial z}\right]\right.
$$

where:

$h=$ pressure head or matric potential [L],

$\Lambda(h)=$ unsaturated hydraulic conductivity $[\mathrm{L} / \mathrm{T}]$,

$\left(^{\prime}(h)=\right.$ specific moisture capacity $=\frac{10}{1 / 2}[1 / \mathrm{L}]$,

$\theta=$ volumetrie water content (volume of water per bulk volume of tuff).

$x, z=$ spatial coordinates $[\mathrm{L}]$, and

$1=$ limo [T].

Basic assumptions needed for the practical mumerical solution of (1) are isothermal and isolabline conditions. Solution of (1) at any later time requiers that $h$ be known ereryhere in space at the beginning of the simulation period, and that any" normal fluxes or different hon the boundary of the solution domain be specificd. These intial and bomndary conditions can be stated mathematically as:

$$
h(r . z .0)=h_{0} . h(x, z, t)=h_{c} \text { and } u(x, z, t)=u_{c} \text {. }
$$

where:

$h_{0}=$ prescribed head liunction of space.

$h_{1 .}=$ prescribed head function of space and time, and

$\because=$ prescribed normal flux function of space and time.

The solution of (1) subject to (2) reguires that $h$ be a single valued function of 0 . That is. whether a material is wetting or drying, the same one-to-one correspondence between 0 and hexists. While this is not rigorously true, at present there is no simple way to account for this type of hysteresis. For the purpose of the present study this last constraint is satislied by the van (ienuchten relationship) (van (ienlluchten. 1980). This relationship) is:

$$
\theta(h)=\frac{\theta_{s}-\theta_{R}}{\left[1+(a h)^{N}\right]^{\pi}}+\theta_{R}
$$


Where:

$\theta_{s}=$ experimentally determined saturated rolumetrie water content.

$0_{R}=$ experimentally delemined residual volumedric water comlent.

$0=$ cures litting parameter $[1 / 0]$.

$. I=1-\frac{1}{v}$, and

$r=$ another crures fitting paramerer.

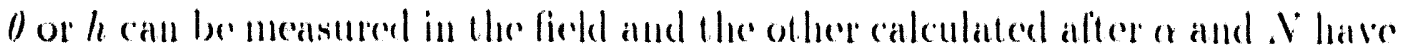
beend determined. 'lo do this. paired values of o and hare generated experimenlally

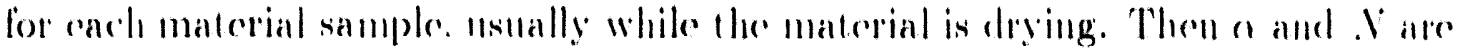
adjusted to minimize the total distance beeweren the experimental data and the theoretical curve described by (3). One may use this information to determine the redative hydranlic conductivity for a corresponding $h(o r)$ arcording to:

$$
h^{n}(h)=\frac{\left[1-(a h)^{N-1}\left[1+(a h)^{N}\right]^{-N /}\right]^{2}}{\left[1+(a h)^{N}\right]^{\frac{H}{2}}}
$$

where:

$\Lambda^{R}(h)=$ relative hỵlraulic conductivity, and

$0 \leq K^{H}(h) \leq 1$.

.ll other variables are as previously defined.

$K^{\prime}(h)$ is then foumd by the relationship $K^{\prime}(h)=K^{R}(h) K^{\circ}$. Where $\mathbb{K}^{5}$ is the experimentally determined saturated hẹdranlic conductivity [L/T']. The required paramoters have all been determined for this study (Stoker, et al. 199) ). and are included in Table 1 and 2 above. The laboratory analysis was performed by Daniel B. Stephens i Associates. Inc. of Albucquercule. New Mexico.

\subsection{UNSAT2 Flow Equation}

The IINSAT: computer program was developed to analyze isolhermal flow in variably salurated porous modia (Davis of al. 198:3). For the purpose of this project it is nsed to describe flow in a vertical plane through conceptually layered matcrials. ('onventional prescribed head and prescribed normal Hux bomelaries

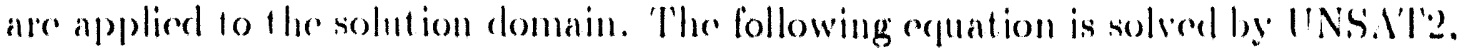
disregarding speecilic storage eflects, and any somrees or sinks: 


$$
\left(\cdot(h) \frac{\partial h}{\partial t}=\sum_{i=1}^{3} \sum_{j=1}^{3} \frac{\partial}{\partial x_{i}}\left[\Lambda^{R}(h) \Lambda_{i j}^{S} \frac{\partial h}{\partial i r_{j}}\right]+\sum_{i=1}^{3} \frac{\partial}{\partial x_{i}} \Lambda^{R}(h) \Lambda_{i 3}^{S}\right.
$$

where:

$x_{i}=$ spatial coordinate $\left(i, j=1,2,3\right.$ with $x_{3}=$ vertical coordinate $)$, and

$\Lambda_{i j}^{*}=$ hydraulic conductivity tensor at saturation.

All other variables are as previonsly defined.

The first term in (5) describes a material's capacity to resist a change in water content for a given change in head, over time. The second term represents adrection, and the third term represents drainage. The conductivity tensor is isotropic (here). A solution to (5) is obtained using the Galerkin finite element method (Davis et al., 1983). For this project the storage properties of the simnlation clomain are considered negligible, which requires the use of a backward difference time integration scheme. The use of finite elements allows specification of irregular domain borders and irregularly layered material. Howerer, the grid developed here is rectangular, with horizontal and vertical spacing that facilitates comparison (of physical and academic significance) with any future finite difference simulations, as the Mortandad canyon modeling effort progresses. The intricacies of the solution procedure cal: be found in Davis et al. (1983).

\section{Lumped Parameter Model}

The lumped parameter model is based on a dynamically connected stream-alluvial acpuifer system. The structural simplicity of this technique is inherently related to the systems operation approach it takes; the system is described only to the degree that it relates averaged input-output-storage changes over time (Stoker, et. al, 1991). For the stream connected (phreatic) alluvial aquifer system located in Mort andad (anyon, a simple water balance equation may be written as:

$$
n \frac{d z}{d t}=4 s-q 0-q E T-q T
$$


where:

$n=$ average effective aquifer porosity $\left[\frac{L^{3}}{L^{3}}\right]$,

$z=$ average saturated allurial acpuifer ihickness $[L]$,

$\frac{d}{d t}=$ total clerivative $\left[T^{-1}\right]$,

$q s=$ stream leakage $\left[\frac{\text { lol }}{\text { dreu.Time }}\right]$,

$\eta_{O}=$ net alluvial acquifer outflow $\left[\frac{V_{0}}{\text { Arfuctime }}\right]$,

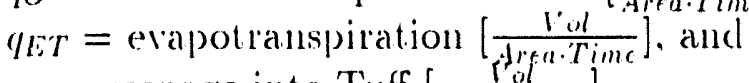

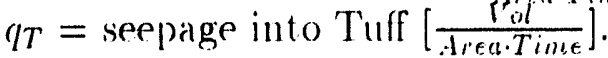

The net aquiler outhow term, qo, is approxinated by a linear relationship given as:

$$
q_{0}=a\left(z-z_{0}\right)
$$

where:

$\approx_{O}=$ stream reference level $[L]$, and

$a=$ a lumped outflow constant $\left[T^{-1}\right]$.

Equation $(\tau)$ is inherently related to Darcy's law. In general, zo can be a function of time, but is usually assumed constant since fluctuation in $\approx_{0}$ are usually much smaller than those for $\approx$ (Stokes, et. al, 1991). Substituting (7) into (6) sielels a differential equation of the form:

$$
n \frac{d z}{d t}+a(z-z o)=E
$$

where:

$E=$ represents the lumped time dependent inputs minus output.

The model represented by (8) is a lumped parameter model in the form of a

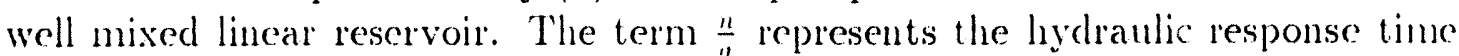
$\left(t_{h}\right)$ of the system since it characterizes the average response time of the water balance equation. Typically $t_{h}$ will vary between one and three months in Mortandad canyon (Stoker, et al., 1991). Numerous analytical solutions lor (8) are 
arailable for a wide variety of initial conditions. Parameters for the model have been estimated from a preliminary calibration performed on monthly field data collected in Mortandad canyon from July 1963 to 1965.

The alluvial acpuifer can be thought of as a long rectangular volume of salurated sediments that follows the canyon axis under the stream channel, on top of the tuff. This volume of material has a surface area of $40 \mathrm{ft}$. by $7,200 \mathrm{ft}$.. and a thickness (:) described by (6). The $\tau, 200$ it. distance represents the length of upper/middle Mortandad canyon. The seepage area in each computer simulation domain represents one-hall of the 10 lt. wide saturated sediment box. The simulation comain border that extends vertically down beneath the secpage area (see Figs. 2 and 3) (anl be thought of as a symmetry axis, about which the flow pattern is mirrored. Equation (6) is solved for $q_{T}$, which is applied as a flux boundary condition in the secpage area.

\section{Computer Simulations}

\subsection{Boundary and Initial Conditions}

Saturation can be defined as the volume of water per volume of pore space, i.e.:

$$
S=\frac{\theta_{i}-\theta_{R}}{\theta_{s}-\theta_{R}}
$$

where:

$0 \leq 6 \leq 1$

For a given $S, \theta_{S}$, and $\theta_{R}$, one can solve for the corresponding $\theta_{i}$, and then compute $h$ using (3), providing $\alpha$ and.$V$ have been determined for that material. Initial head configurations for the following simulations are based on an assumed initial saturation value of 0.20 (20 percent). Table 3 shows the matric potential computed for various levels of saturation in corehole MCM 5.9A. Saturation slightly less than $20 \%$ produced values for $h$ that represent a very dry condition. This caused convergence problems during run time as a result of steep matric potential gradients in front of the infiltrating water and discontinuities in hacross material interfaces. Saturation greater than $20 \%$ is essentially a wet system that does not match observations of in-situ water content taken to be similar to those observed at depth in the Otowi. Table 4 is a summary of similar clata for coreliole MC'.M. ..1. 


\begin{tabular}{|c|c|c|c|c|}
\hline $\begin{array}{l}\text { Sample Number } \\
\text { (corehole M('M 5.9A) }\end{array}$ & $\begin{array}{l}\text { Material } \\
\text { Number }\end{array}$ & $\begin{array}{c}h(-[\mathrm{t}) \\
(S=0.05)\end{array}$ & $\begin{array}{l}h(-l \mathrm{lt}) \\
(S=0.10)\end{array}$ & $\begin{array}{l}h(-l \mathrm{t}) \\
(S=0.20)\end{array}$ \\
\hline$M(1 \mathrm{M} 5.9 \mathrm{~A} 85.5-86.0$ & 9 & 2046 & 268 & 35 \\
\hline$M\left({ }^{\prime} M 5.9 \lambda 94.5-95.0\right.$ & 8 & 106 & 94 & 22 \\
\hline$* M(: M 5.9 \mathrm{~A} 104.5-105.0$ & $\tau$ & 391 & 151 & .58 \\
\hline$* M($ 'M 5.9A 109.0-109.5 & 6 & 3067 & 660 & 141 \\
\hline$M(\mathrm{M} 5.9) \wedge 119.5-120.0$ & 5 & 476 & $1: 35$ & 38 \\
\hline$M(1 M 5.9 A$ 124.5)-125.0 & $t$ & 128 & 58 & 26 \\
\hline$M(\mathrm{M} 5.9 \Lambda 129.5)-130.0$ & 3 & 151 & 71 & $3: 3$ \\
\hline$M(\mathrm{M} 5.9 \Lambda 1+49.5-150.0$ & 2 & 318 & 121 & 48 \\
\hline M('M 5.9A $164.5-165.0$ & 1 & 315 & 115 & $4 \cdot 2$ \\
\hline
\end{tabular}

$\left(^{*}=\right.$ Tsankawi Member).

Table 3: Matric potential values ( $h$ ), for cores from M( $M$ 5.9A, calculated using (3), assuming $s=0.05,0.10$, and 0.20 .

\begin{tabular}{|c|c|c|c|c|}
\hline $\begin{array}{l}\text { Sample } \\
\text { Number }\end{array}$ & $\begin{array}{l}\text { Material } \\
\text { Number }\end{array}$ & $\begin{array}{c}h\left(-f^{\prime} t\right) \\
(S=0.05)\end{array}$ & $\begin{array}{c}h(-1 \mathrm{t}) \\
(S=0.10)\end{array}$ & $\begin{array}{c}h(-\mathrm{ft}) \\
(S=0.20)\end{array}$ \\
\hline$M(M 5.1+3.0-43.5$ & 12 & 1515 & 617 & 249 \\
\hline M('M 5.1 5.3-5.4 ('HEM & 11 & 111 & 51 & $2: 3$ \\
\hline$M(1 M 5.157 .5-58.0$ & 10 & 300 & 106 & 37 \\
\hline$M\left({ }^{\prime} \mathrm{M} 5.163-6+\right.$ ('HEM $^{2}$ & 9 & 2625 & 492 & $9 \cdot 2$ \\
\hline M('M 5.1 67.0-67.5 & 8 & 718 & 205 & $5 \delta$ \\
\hline$M(115.172 .0-72.5)$ & 7 & 1238 & 302 & 73 \\
\hline$M(1 \mathrm{M} 5.182 .0-82.5$ & 6 & 491 & 152 & 47 \\
\hline M('M 5.1 87.0-8T.5) & 5 & 1272 & 327 & 84 \\
\hline$M(M 5.192 .5-93.0$ & $t$ & 956 & $3+1$ & 121 \\
\hline *M('M 5.1 (94.5-.95.5 & 3 & $9: 36$ & 235 & 59 \\
\hline *MICM $5.197 .0-97.5$ & 2 & 6662 & $209: 3$ & 6.51 \\
\hline$* M(M .5 .1107 .0-107.5$ & 1 & 5.54 & $1: 31$ & 31 \\
\hline
\end{tabular}

(* = 'Tsankawi Momber)

'Table 4: Matric potential values ( $h$ ). for cores from M('M 5.1, calculated using (3). assuming $S=0.05,0.10$, and 0.20 . 
Material properties as clescribed by van (ienuchten parameters are assumed to form planar layers that extend infinitely into space. A point equidistant between core samples was arbitrarily chosen to represent a material boundary. except at the boundary between the Tsankawi member and the material above and below it. The location of this ma jor lithologic contrast was determined from the driller's $\log$.

('orchole $\mathrm{MC}(\mathrm{M}$ 5.9A is $1.94 \mathrm{ft}$. deep, and is taken to accurately represent the top $200 \mathrm{ft}$. of material beneath the surface of the canyon bottom. The uppormost $38 \mathrm{ft}$. of this material is allurim, and the remaining $162 \mathrm{ft}$. is the primary focus of this mocleling effort. Talle 5 is a summary of gravimetric water content data for MIC 'M 5.9A core samples, with elevation given above this arbitrary 200 [1. depth datum. Daniel B. Stephens \& Associates, Inc. determined parameters for the samples indicated. The remaining samples had gravimetric water content determined during a radiochenical analysis performed at LANL. The volumetric water content for these samples was computed using values for bulk density, material density, and porosity from adjacent tested samples. The relationship betwoen these parancters is:

$$
\rho_{b}=\rho_{m}(1-\phi) \text { and } \theta_{v u l}=\theta_{g r a v} \frac{\rho_{h}}{\rho_{l}}
$$

whore:

$\rho_{b}=$ bulk density $\left[\frac{\| B_{u} l k}{l^{2} B u(k)}\right]$.

$\rho_{m}=$ material density $\left[\frac{M \text {. Sulid }}{L^{\prime} \text { Sodidi }}\right]$.

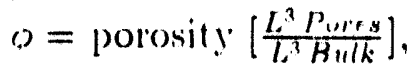

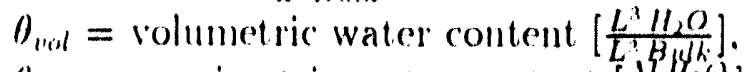

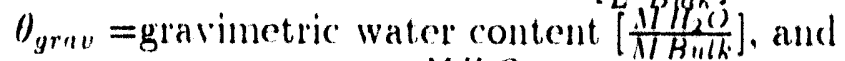

$\rho_{l}=$ density of water $\left[\frac{\mathrm{Al} \mathrm{H}_{2} \mathrm{O}}{L^{2} \mathrm{I}_{2} \mathrm{O}}\right]$, taken to be $1.0 \frac{\mathrm{grnm}}{\mathrm{cm}^{2}}$. 


\begin{tabular}{|c|c|c|c|c|c|}
\hline $\begin{array}{l}\text { Saniple } \\
\text { Elovation }\end{array}$ & $\begin{array}{c}\theta_{\text {grav }} \\
\left(\frac{g \mathrm{H}_{2} \mathrm{O}}{\mathrm{B}_{\mathrm{Bu}}}\right)\end{array}$ & $\begin{array}{c}\rho_{b} \\
\left(\frac{g H_{u l k}}{c m \cdot 1 B u k}\right)\end{array}$ & $\left(\frac{\rho_{m}}{\text { gsivlid }}\right)$ & $\begin{array}{c}\phi \\
\left(\frac{\mathrm{cm}^{3} p_{\text {orea }}}{\mathrm{cm} m^{3} B_{u k}}\right)\end{array}$ & $\begin{array}{c}\theta_{v o l} \\
\left(\frac{c m^{3} \|_{2} O}{\left.m^{3} B_{w 1}\right)}\right)\end{array}$ \\
\hline$|6|$ & .149 & $1.00+$ & $2.32+$ & $.569+$ & $.149+$ \\
\hline liv & .195 & $1.00+$ & $2.32+$ & $.569+$ & $.195+$ \\
\hline 156 & 189 & $1.00+$ & $2.32+$ & $.569+$ & $.189+$ \\
\hline [iiis & .104 & $1.00+$ & $2.32+$ & $.569+$ & $.10 .1+$ \\
\hline 1.51 & .192 & $1.00+$ & $2.32+$ & $.569+$ & $.192+$ \\
\hline 116 & .238 & $1.00+$ & $2.32+$ & $.569+$ & $.238+$ \\
\hline $1: 36$ & .183 & $1.00+$ & $2.32+$ & $.569+$ & $.183+$ \\
\hline $1: 11$ & .194 & $1.00+$ & $2.32+$ & $.569+$ & $.199+$ \\
\hline $1: 2 !$ & .181 & $1.00+$ & $2.32+$ & $.569+$ & $.181+$ \\
\hline 121 & 256 & $1.00+$ & $2.32+$ & $.569+$ & $236 i+$ \\
\hline $115 .$. & .391 & 1.00 & 2.32 & .593 & 389 \\
\hline $111 .$. & .354 & 1.99 & $2.32+$ & (5.55) & .388 \\
\hline $111 .$. & .442 & 0.95 & $2.32+$ & .610 & 422 \\
\hline $106 .$. & .114 & 1.52 & 2.332 & .381 & .172 \\
\hline$* !)$ & .065 & $0.92+$ & $2.18+$ & $.628+$ & $.060+$ \\
\hline *!)(i.. & .605 & 0.92 & 2.18 & 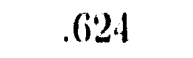 & ה \\
\hline *!)!.. & .493 & 0.90 & 3.18 & (i.3) & .445 \\
\hline$+x(j$ & .218 & $0.92+$ & 2.15+ & $.628+$ & $2 \cdot 29+$ \\
\hline $81 .$. & .214 & 1.08 & $2.31+$ & .557 & .2:3:2 \\
\hline $76 .$. & .161 & 1.11 & 2.31 & .546 & 179 \\
\hline $71 .$. & .185 & 1.05 & 2.31 & .570 & .195 \\
\hline (i6.. & .187 & $1.06+$ & $2.311+$ & $.510+$ & $.199+$ \\
\hline $61 \ldots$ & .189 & $1.09+$ & $2.31+$ & $.5: 30+$ & $.205+$ \\
\hline $56 .$. & .177 & $1.09+$ & $2.31+$ & $.5: 30+$ & $.19: 3+$ \\
\hline $51 .$. & .190 & 1.16 & 2.31 & 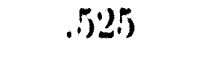 & 221 \\
\hline $16 .$. & .171 & 1.24 & 2.31 & .192 & .217 \\
\hline 11 & .15 .5 & $1.18+$ & $2.311+$ & $.190+$ & $.18: 3+$ \\
\hline $36 .$. & .168 & 1.26 & 2.31 & .185 & 212 \\
\hline $31 .$. & .158 & $1.20+$ & $2.31+$ & $.480+$ & $.19(0+$ \\
\hline $20 .$. & .159 & $1.20+$ & $2.31+$ & $.180+$ & $.191+$ \\
\hline $21 .$. & $.15 !)$ & $1.20+$ & $2.31+$ & $.180+$ & $.|9|+$ \\
\hline $16 .$. & .165 & $1.22+$ & $2.331+$ & $.170+$ & $.202+$ \\
\hline 11 & .152 & $1.22+$ & $2.331+$ & $.170+$ & $.185+$ \\
\hline
\end{tabular}

(* = Tsankawi Member, .. = D). B.Stephens, Lnc.. $+=$ assumed values)

'Table 5: Measured gravimetric water content, and calculated volumetric watce content where noted. Bulk and material density assumed where noted. 
Figure I represents observed volumetric water content in MC M 5.9 A witl distance above the $200 \mathrm{ft}$. depth datum. using the data from Table 5. . An oberervation made from this figure is that water content generally increases on top of the two material interfaces. The Tshirege Unit $1 \mathrm{~d}$ has a finer pore structure than the Tsankawi below it. and water content is thought to increase on this interfice due to the capillary barrier offect. That is, there is no potential for the fince malerial

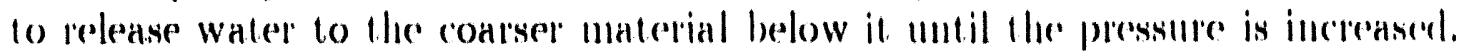
The pressule increases with ant associaled increase in water content on the materiat interface. and the waler flows out of the liner material. On the other hented.

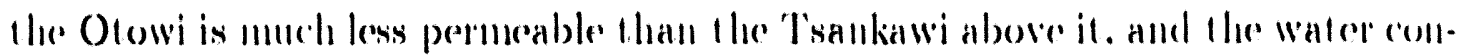
tent increase on this interface is thonglit to be a result of this restriction to lluw. lig. I shows that the two large increases in water content do not occur exactly. at the interfaces. This is attributed to some uncertainty in the exact location of the material boundaries as represented on the figure. If the $20 \mathrm{lt}$. Hhick band of

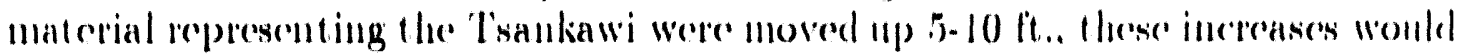
oceur very close to the material interfaces. Howereer, there is no justification to rhange the location of the interfaces in the references, and this clata is used to aceess the general validity of the computer simulations.

The simnlation domain dimensions vary in widl hand depth to prevent moring water from encountering any prescribed no llow boundaries and to facilitate comvergence by keeping grid size to a minimum. All boundaries are no llow except for the seepage area (sere Fig. 3), which is present in the nppere left-hand cormer of all cont onte plots. This portion of the boundary has thee conditions prescribed on it.

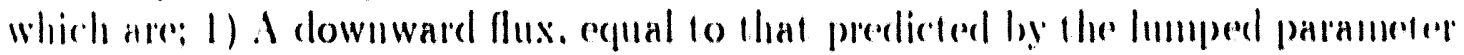
model. of $y / T=5.6 \times 10^{-3} \mathrm{lt} . /$ lay (Mclin. pers. cons'. report in progress): 2 ) 1 constint (ponded) head equal to $1.0 \mathrm{fl}$. of water: 3). In order of magnitmele

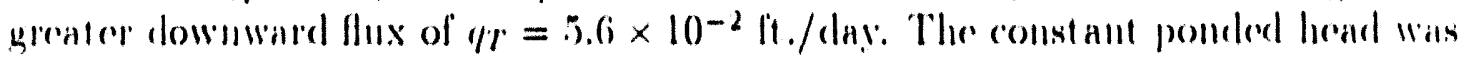
rhosen to represent the base of the allurium which is intermiltently and rariably: ponded. but usually saturated in the area near M( .915 .94$.

\subsection{Finite Element Simulations}

The V.VSAT2 inpul files and souree code used to generate the remaining ligures are included in the appendix. All finite element simulations were performed on

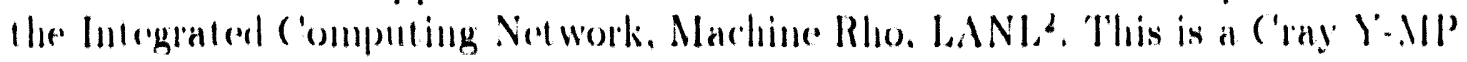

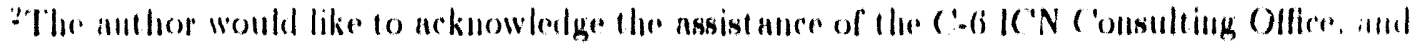
Jim linhere for his assitance on porting coste to llae ('ray.
} 


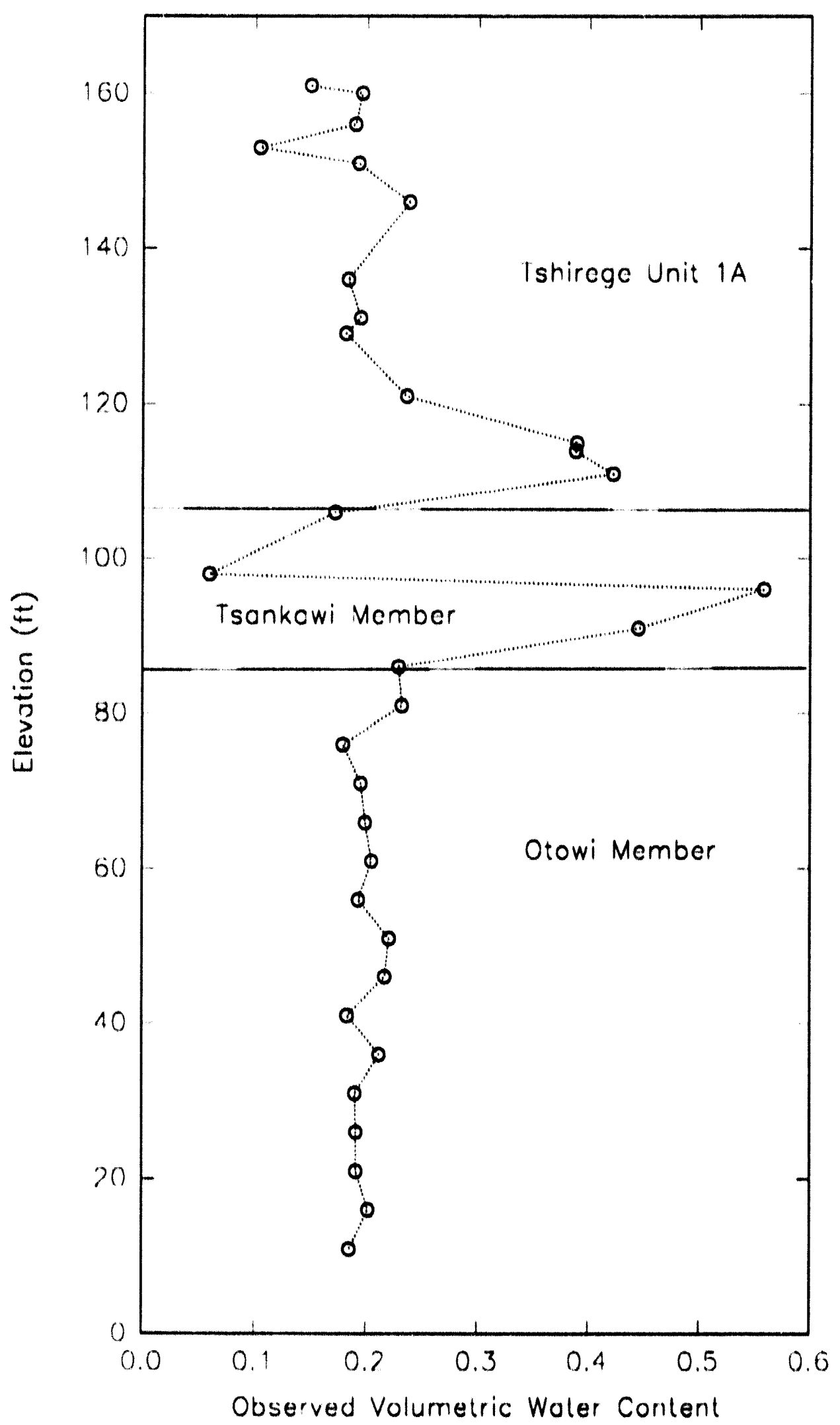

1"g. 4: Obscrved volumetric water content with clevation in corehole MCM 5.9A, bosed or date in iable 5. 
running INIC'OS, ver. 6.0.1. The UNSA'T2 linite element grid nsed to generatse Figs. 5, 6, and 7 , had ' $x$ ' direction nodes spaced 6 at 5.0 lt. apart, 1:3 at 10.0 ft., and 6 at $15.0 \mathrm{ft}$. from the symmetry axis. and 'y direction nodes spared 250 at $2.0 \mathrm{ft}$. apart. 100 at $1.0 \mathrm{ft}$. and 1.21 at $0.5 \mathrm{ft}$. from the base of the

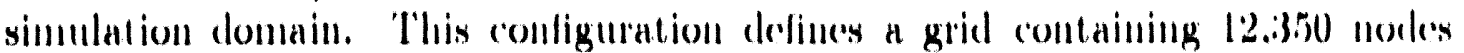
(11.850) elements). ('Pl lime was approximately 1000 seconds for the 100 yerat

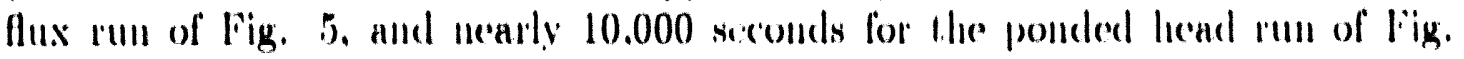

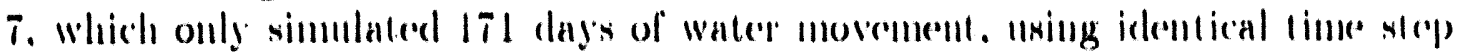
controls. The large difference in computational edfort for two iclentical griels is a result of the non-linearity of the unsaturaterl llow expuntion. Siperificalls. Here capacity torm in (1) canses a discoutinuity to occur where the change in matric potential (alle) becomes very large. In infiltration problems with sereral materials this sillution will arise across the wetting front of the permeat ing fluid. and acress material interfaces where the matric polential geadient is initially discontinuons.

Fig. is $i$ show contonts of pressure head (in foert). Theres are no saturated norkes in the profile of Fig. 5. Whater movement is entirely by unsaluraled flow. Fig.

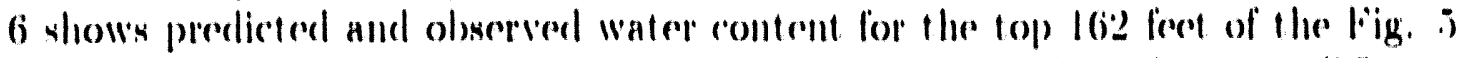
flux run. ('omparison of liggs. is 8 ( 6 is not obvious as a result of the many different matcrials usecl. Fig. 5) slows matric potential increasing (becoming lews negative) on top of and through the 'Tsankawi, as we move toward the symmetry axis. The rhanges are on the ordere of tens of fere. Fig. 6 shows the associated increase in

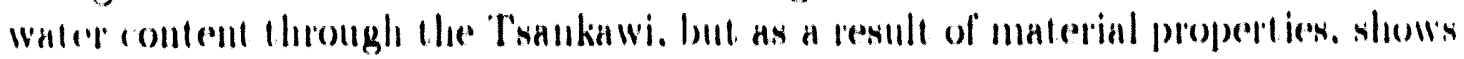
the water content dropping off on top of the T'somkanwi. This is easily understood

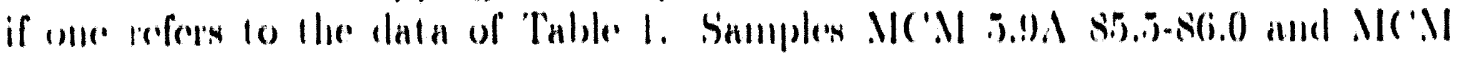

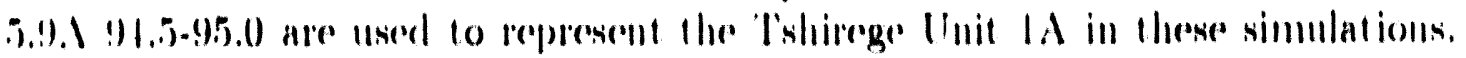

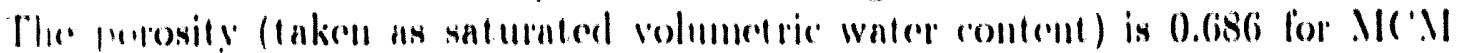

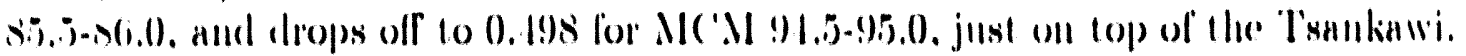

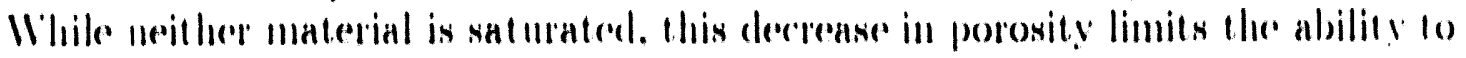

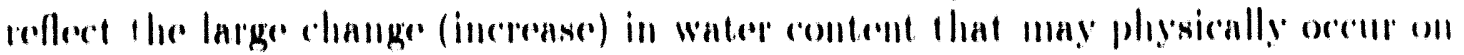

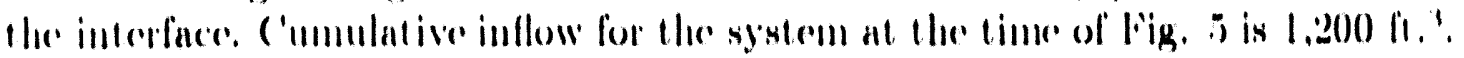

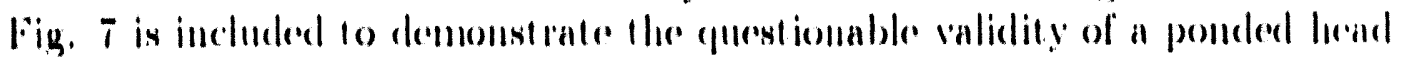
boundary condition in the serpage area. Olsererations of water content at the base of the allurium typically show saturated sediments on the order of serereal feet thick. Fig. $T$ shows that one foot of ponded head on this system saturaterl

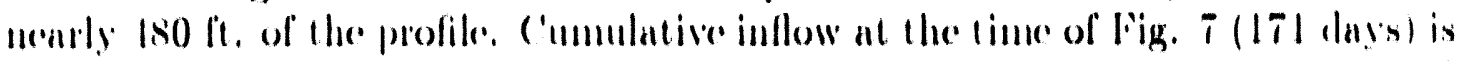

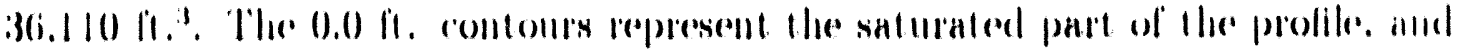

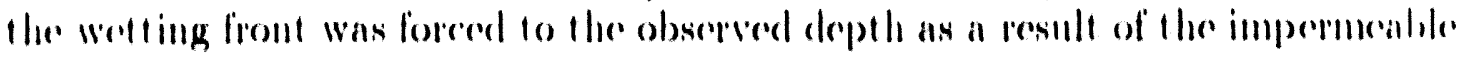


MCM 5.9A (BB'). 100 yoors of 0.0056 fldoy flux in soopoge oroo.

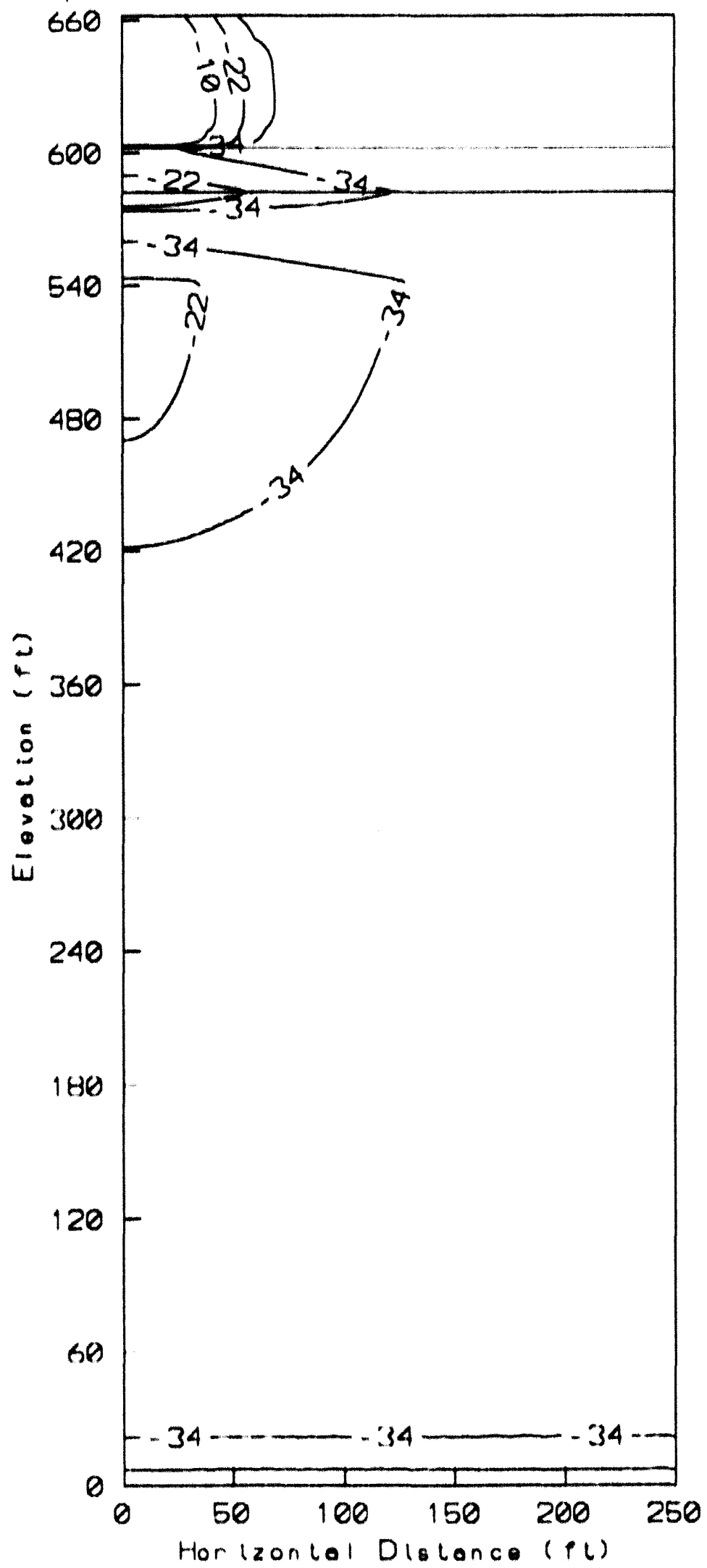

Fig. 5: liNSAT2 simmlated matric potcontial contoms (iin feet) for lon years of $0.0056 \mathrm{ft}$. day. Hux in seepage area. ('ross-section consists of material in 'ablo 1. MC M $5.9 \mathrm{~A}$. 


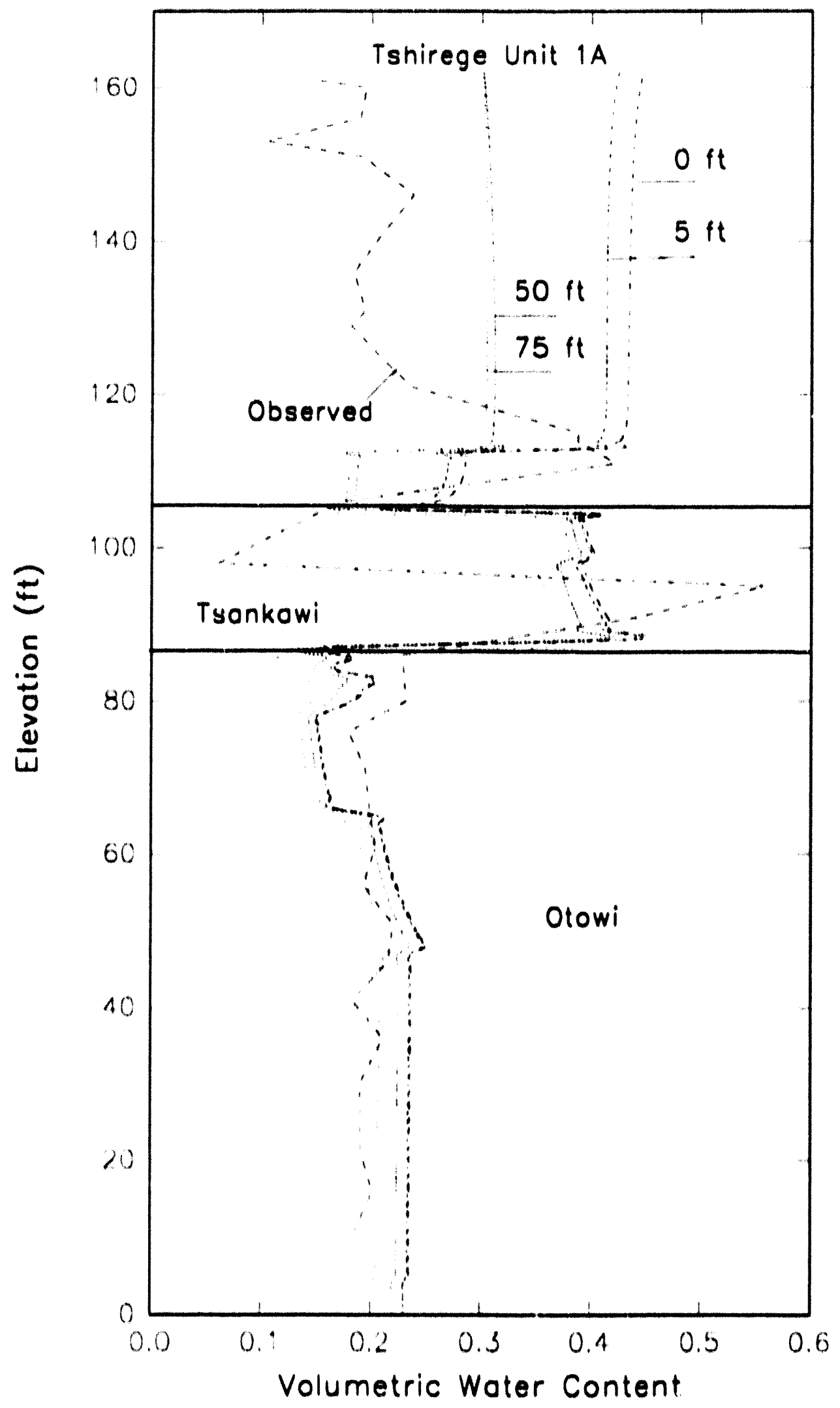

Fig. 6: UNSAT2 simulated water content at $x=0,5,50,75 \mathrm{ft}$. from symmetry axis for upper $162 \mathrm{ft}$. of Fig. 5 , after 100 years of $0.0056 \mathrm{ft} / \mathrm{d}$ flux in seepage area. 
MCM 5.9A $\left(B B^{\circ}\right), 171.78$ doye of $1.0 \mathrm{fl}$ ponded heod.

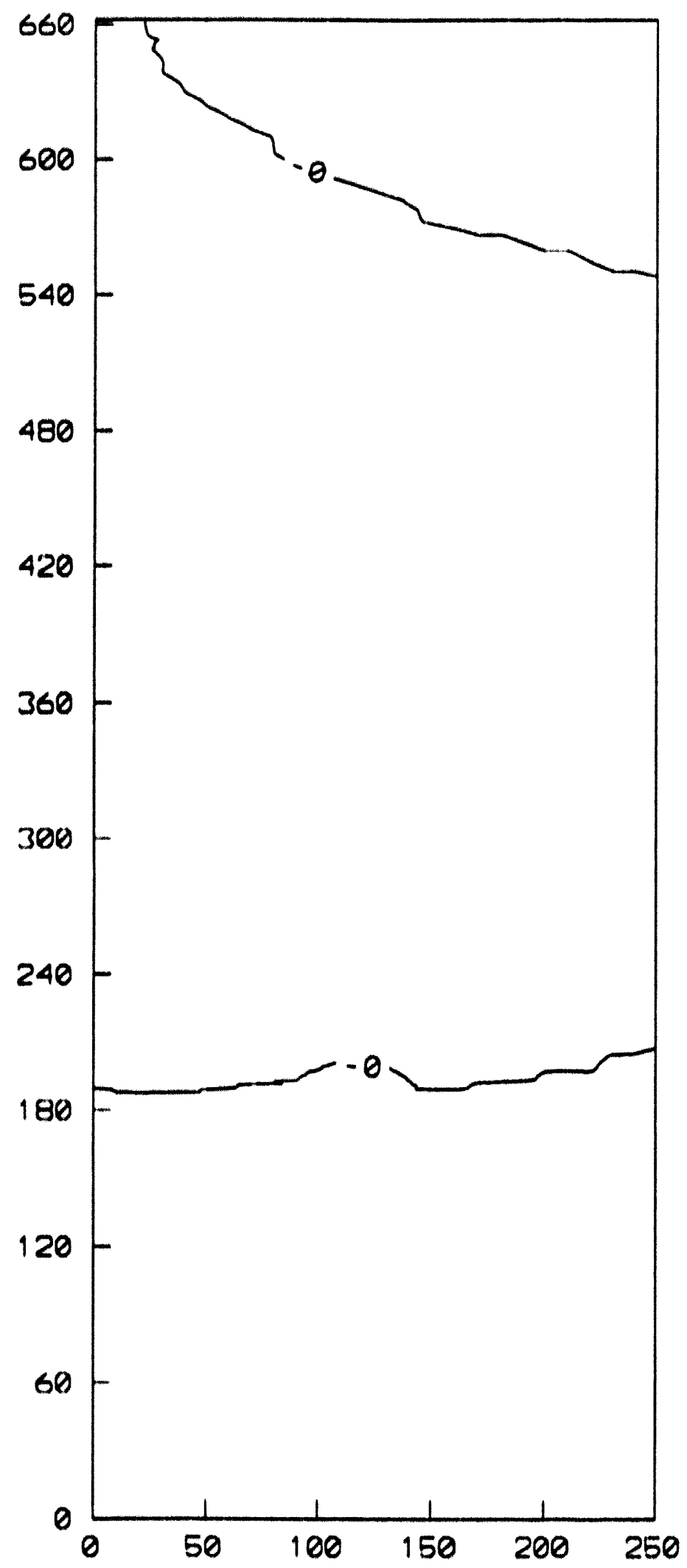

Fig. T: UNSALT2 simulated matric potential contours (in feret) for 171.78 dan's

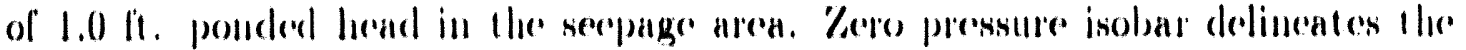
saturated region in the profile. ('ross-section consists of material in 'Table I. MIC 'MI 5.9 .1 . 
bommdary at $x=250$ ft. from the symmenty axis. At this point in the study several variations in node spacing and grid dimension were tested to arrive at a reasonable solution of the ponderl head problem. Many convergence problemes occurred as a

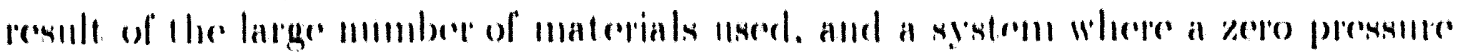

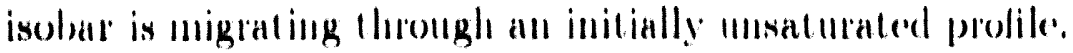

Increasing compulational time and expernse necessitaled a simplifying of hore

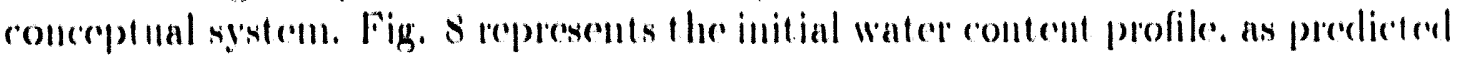

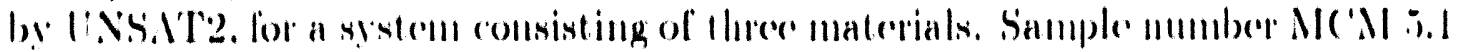

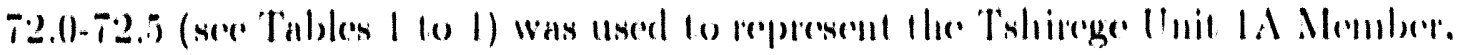

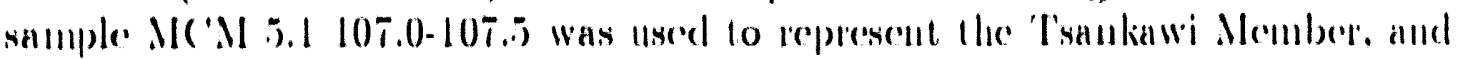

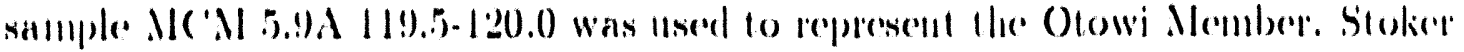

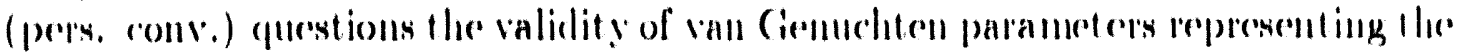
T'shirege Unit 1 I material in $.1(\mathrm{X} / 5.9 \mathrm{~S}$, as a result of the sampling procedures userel during coring. Table 1 shows the the saturated hẹdranlic conductivity of this matrerial to be munch greater and more variable than values all corresponding

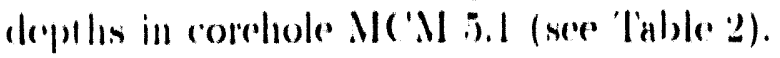

Fies, 9, 10, and 11. show ponded head simmlations at 1.3. 11.2 . and 21.9 y rats

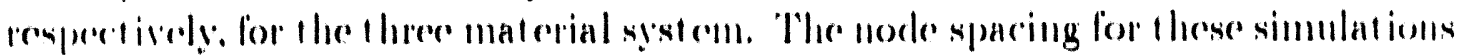
is 10 al $5.0 \mathrm{lt}$. apart. and lis at $10.0 \mathrm{lt}$. apart from the symmetry axis. and 112 at 1.0 It. apant from lhe base of the simmlation domain. This defines a grid of 2:3.1:25 nodes (22.660 clements). The infiltrating water in these simulations dial and feel the impermenble boundary at $x=500$ fi. from the symmetry axis.

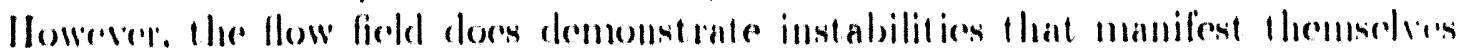

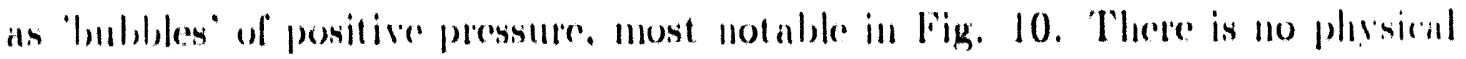

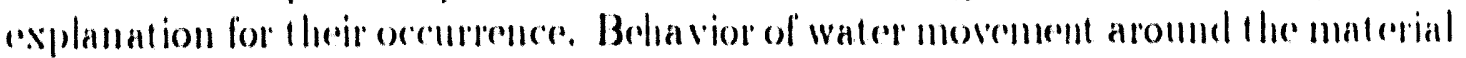

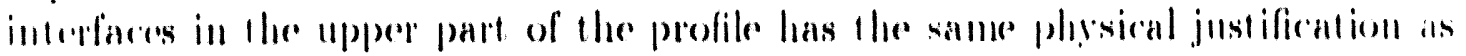

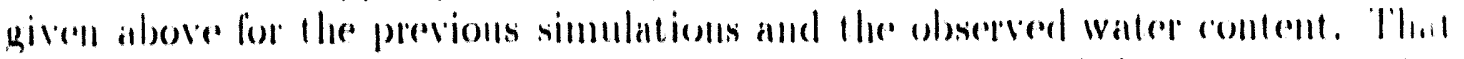
is. matrie potential increases on top of the T'sankawi (towad the symmetry asio).

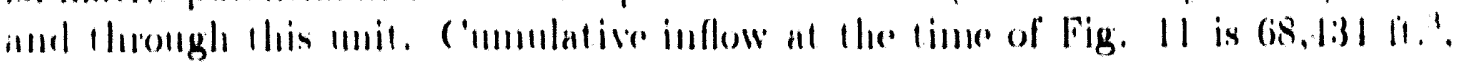
which is remotely consistent with nearly 125 ft. of saturated sedimonts at her base of the simmlation domain! Fig. I2 is a plot of simmlated and observerl winter

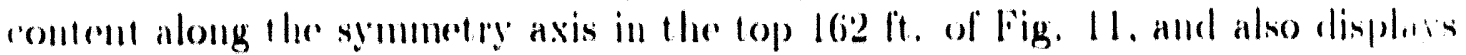
lhe lealueses that have no physical explanation, hamely the two large increases in

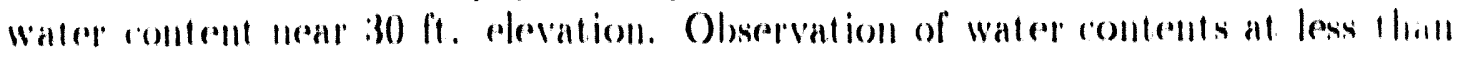

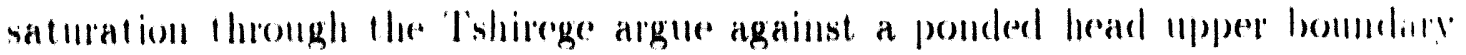
romblition. Dinsaturated flow is recpured to allow this material to remain all lows

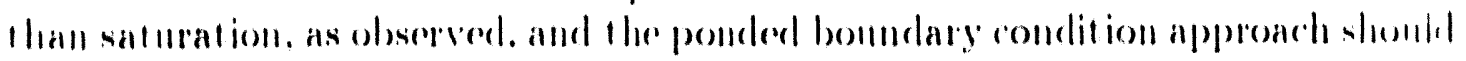




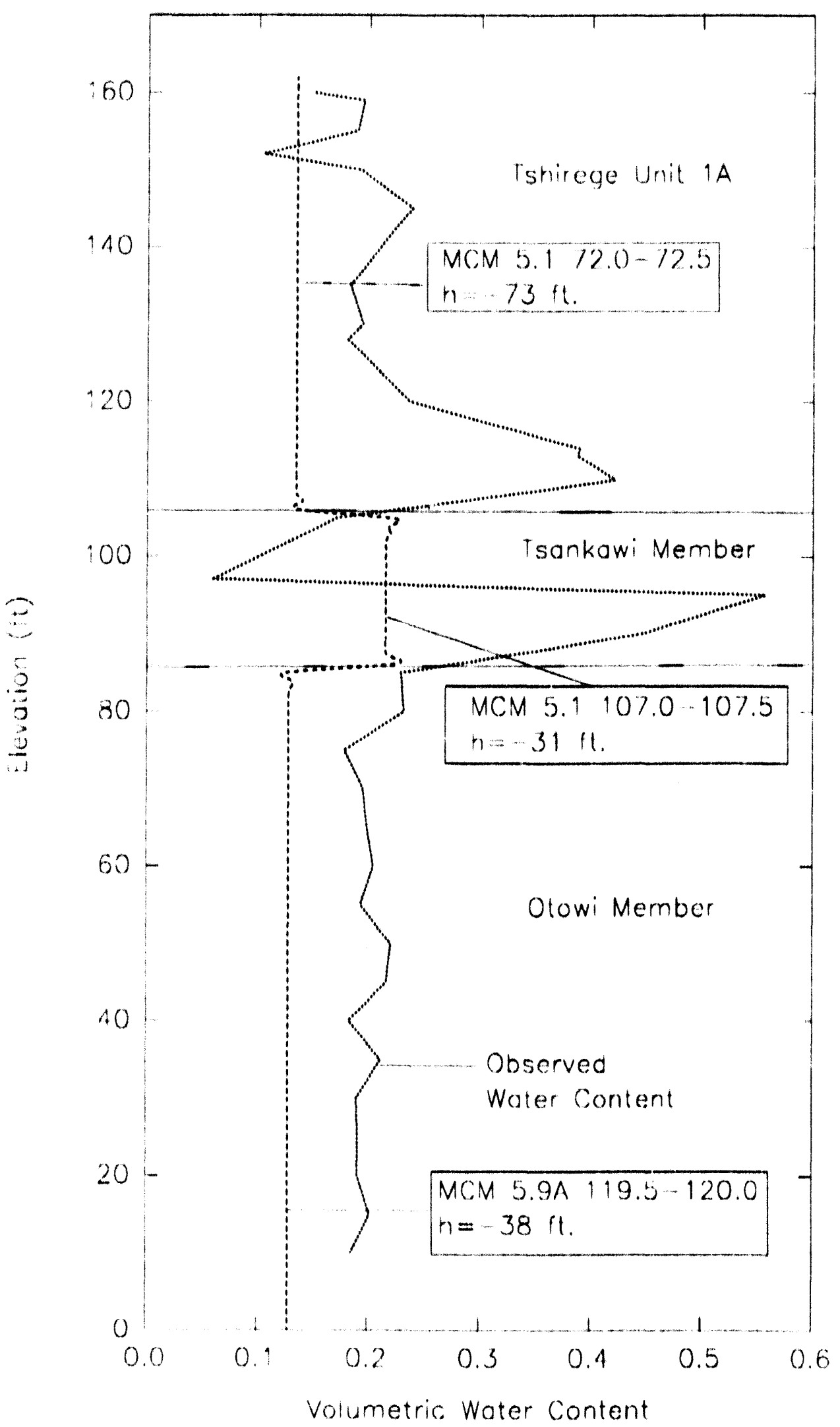

- 6. 8: Initiol water content profile for composile woss section ( 3 moterials) at $20 \%$ saturation as predicted by UNSAI2. 
Compos the proflle, 4.3 yeors of $1.0 \mathrm{ft}$. ponded heod.

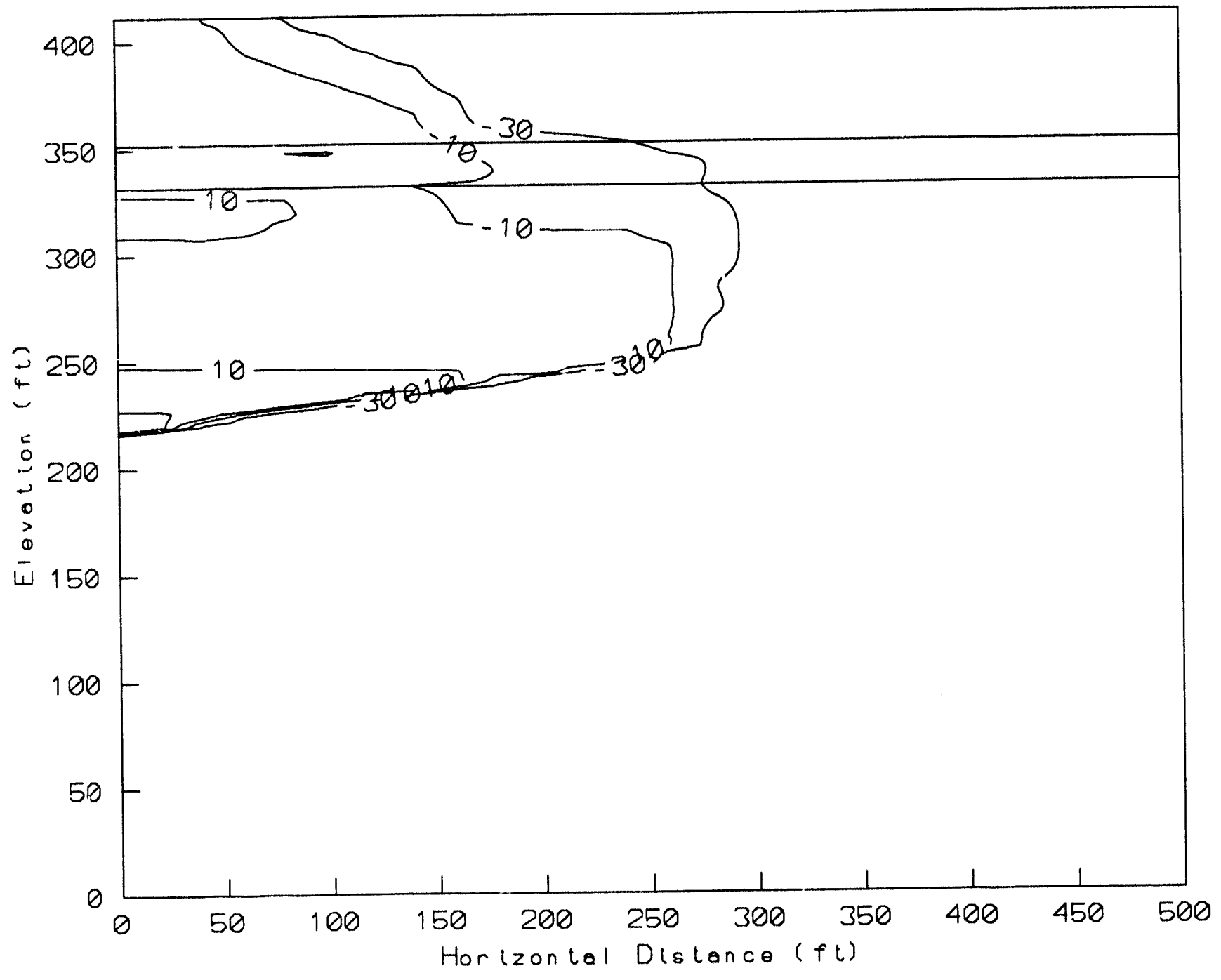

Fig. 9: WNSAT2 simulated matric potential contours (in feet) for 4.3 years of $1.0 \mathrm{ft}$. ponded head in seepage area. Composite cross-section consists of three materials. 
Compostle proftle. 11.2 years of $1.0 \mathrm{ft}$. ponded hood.

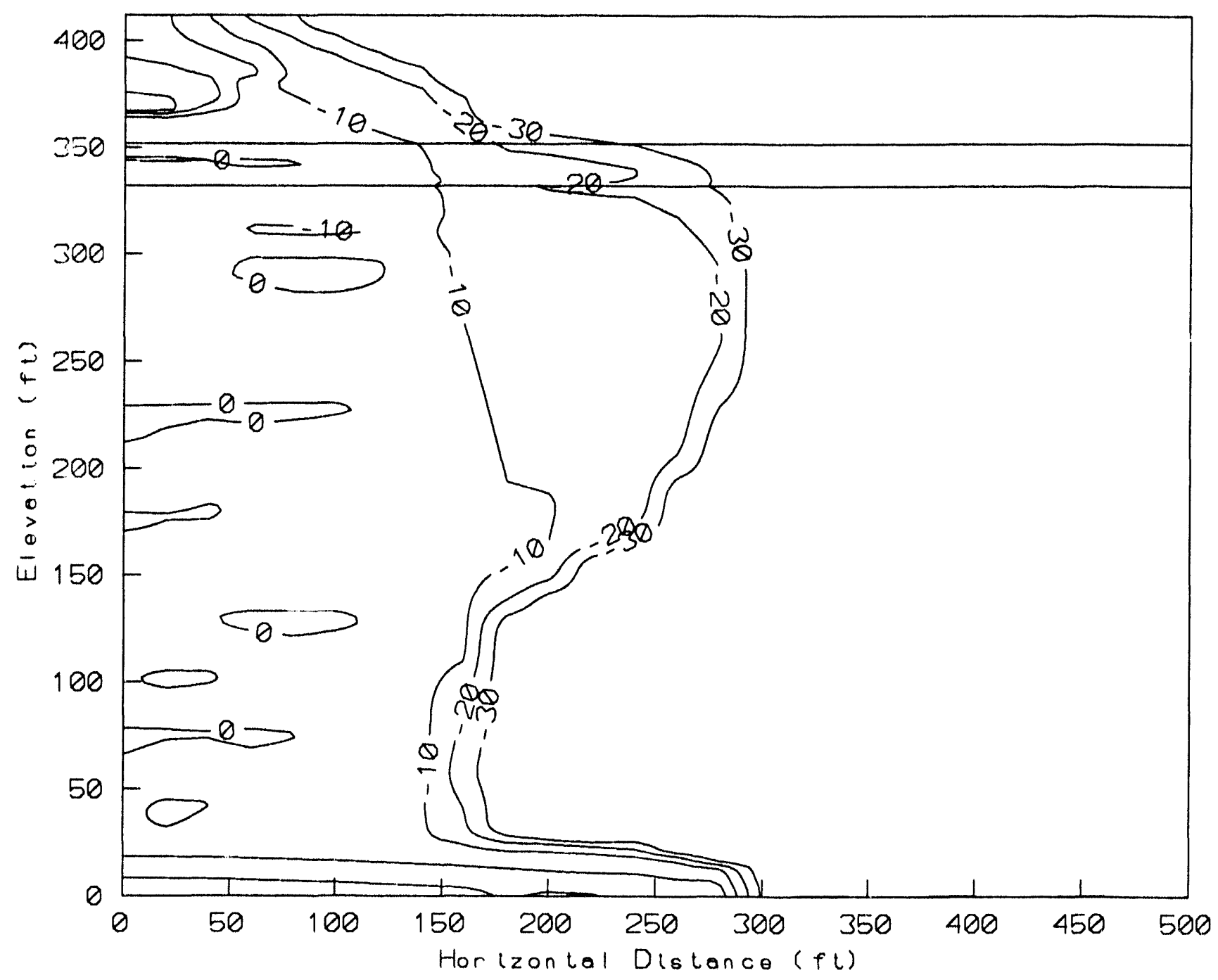

Fig. 10: UNSAT2 simulated matric potential contours (in feet) for 11.2 years of $1.0 \mathrm{ft}$. ponded head in seepage area. Composite cross-section consists of three materials. 
Compostle proflle, 24.9 years of $1.0 \mathrm{fl}$. ponded hood.

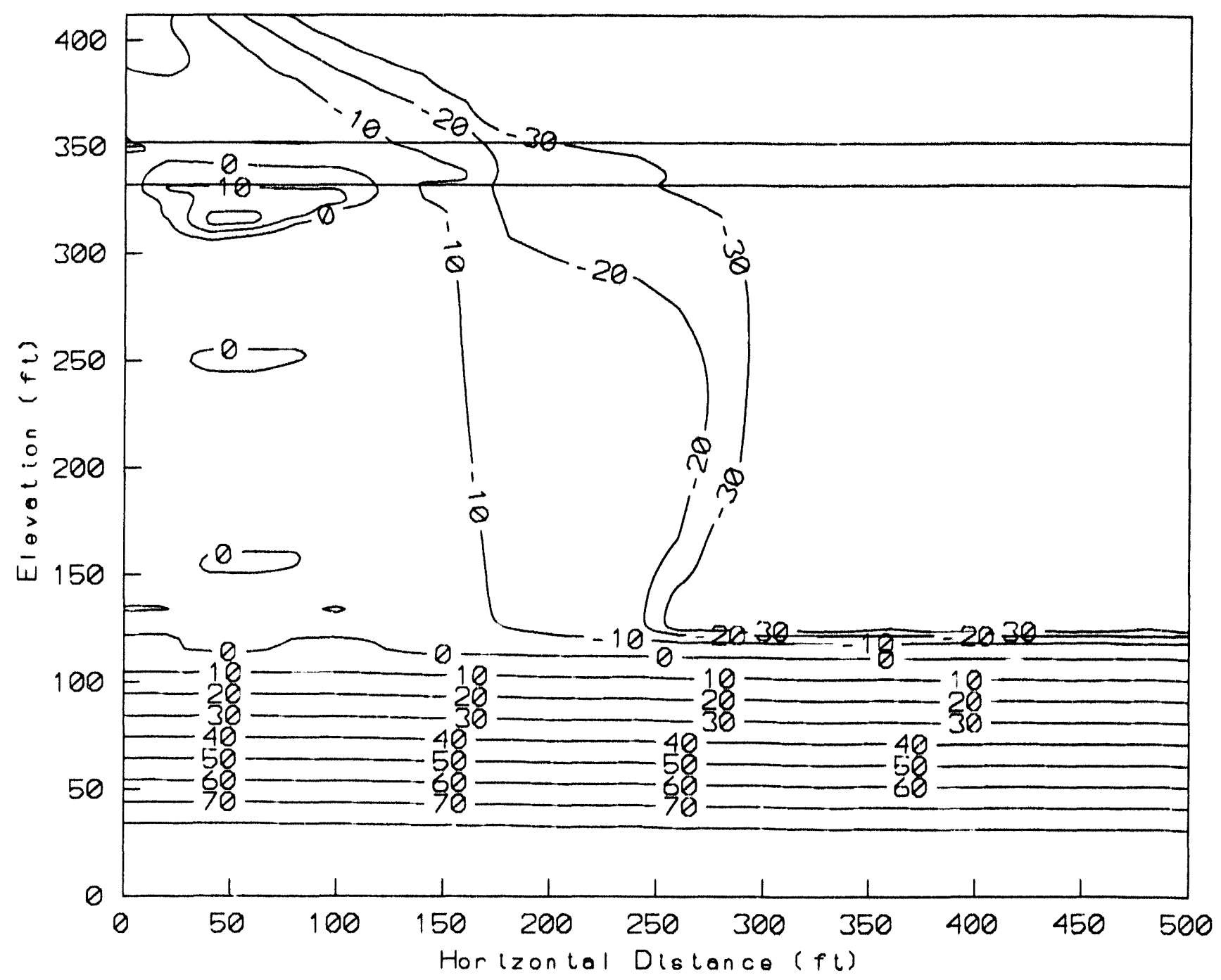

Fig. 11: UNSAT2 simulated matric potential contours (in feet) for 21.9 years of $1.0 \mathrm{ft}$. ponded head in the seepenge area. ('omposite cross-section consists of three materials. 


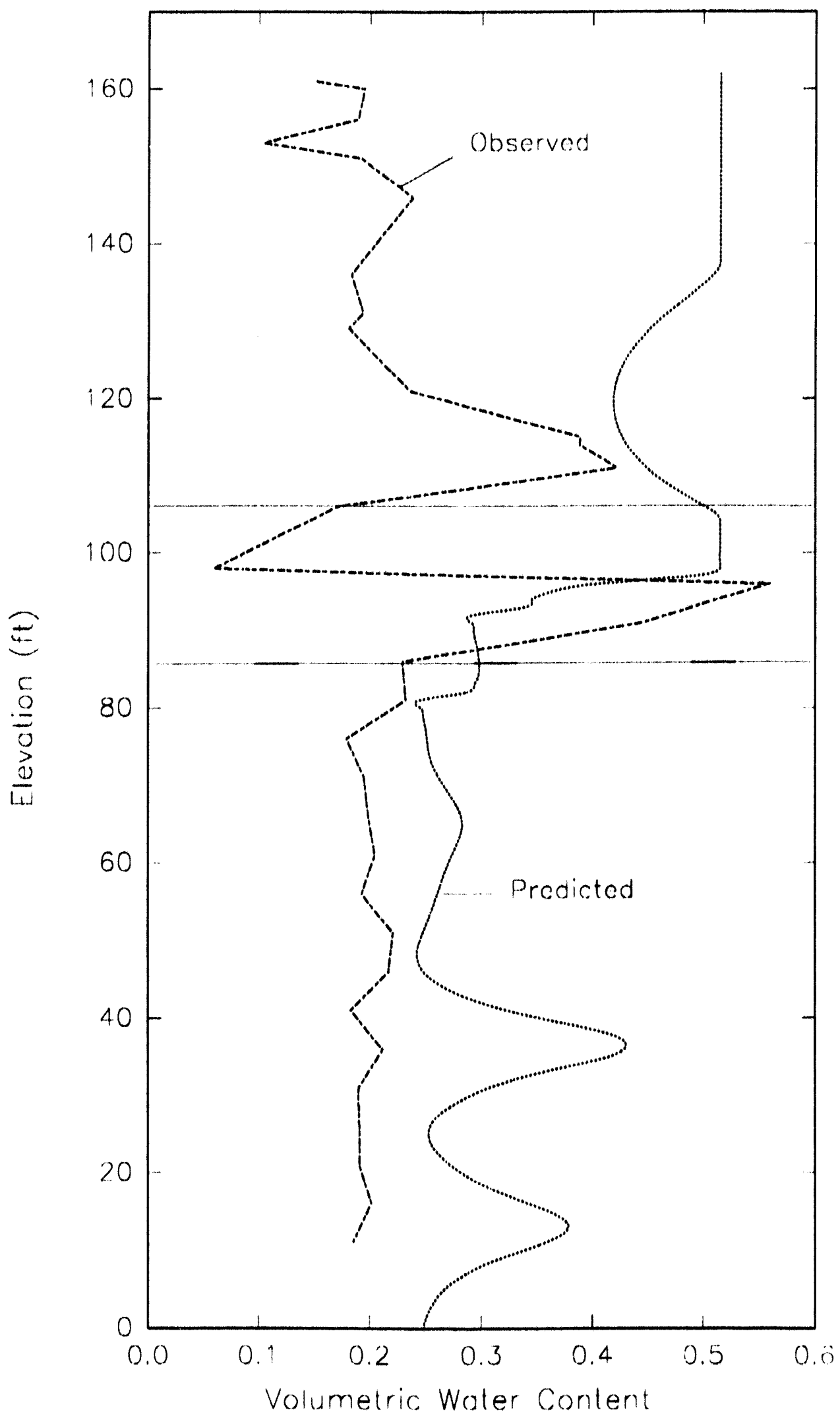

Fig. 1\%: Predicted and Observer water content tor 24.9 years of $1 \mathrm{ft}$. ponded head, at $x \mathrm{O} \mathrm{fi}$. from symmetry axis. 
not be pursued.

Figures 13, 14, and 15, show water infiltrating the composite profile at a rate of $q_{T}=0.056 \mathrm{ft}$. $/$ day. This value represents an order of magnitude increase in the lumped parameter model predicted infiltration rate. Several saturated norles occur at the base of the simulation domain as a result of redistribution within the profile, otherwise water movement is by unsaturated flow. Ciravity appern's to play a larger role than capillarity in causing the matric potential contours to migrate clownward. Their configuration exhibits very little capillary spreading of the moisture plume. Fig. 16 and 17 show the simulated water content profile in the top 162 leet of Figures 14 and 15 respectively. Cumulative inflow at the time of Fig. 14 was $2,191.5 \mathrm{ft}^{3}$, and was $3,171.5 \mathrm{ft}^{3}$ at the time of Fig. 15. 'The oscillation of the water content plot for $x=0,5$, and $15 \mathrm{ft}$. through the Otowi (on Fig. 1i) can only be described as numerical instability.

\section{Conclusions and Discussion}

Figures 16 and 17 show the migration of a high water content peak through the Tsankawi. A plausible explanation for the occurrence and movement of this peak could be that water leaving the Tshirege does so at a saturated conductivity controlled rate of $K_{S}=1.4 \times 10^{-4} \frac{\mathrm{cm}}{\text { eec }}$, while the Tsankawi is able to move it away from the contact at a faster rate of $K_{S}=13.0 \times 10^{-4} \frac{\mathrm{sm}}{\mathrm{sec}}$, resulting in decreased water content just below the interface. While the Tsankawi is filling with watcr from above, it is also being drained from below. The peak occurs because the Otowi is able to move water out of the Tsankawi slightly faster than it enter's from the Tshinrege. (Saturated conductivity of the Otowi is $K_{S}=7.9 \times 10^{-4} \frac{\mathrm{sm}}{\mathrm{nen}}$.) The system dy'namics are very complex and the peak could also be attributed to some type of dynamic equilibrium, not allowing the Tsankawi to simply drain. Figure 15 shows a good correspondence between observed (shown on Fig. 15 and in Fig. 4) and simulated water content tendency (increasing and decreasing in tanclem) from the top of the Tsankawi Member downward. However, thete cloes not seem to be any way to simulate the observed water contents in the Tshirrge with water flowing in from the top of the profile. With any upper boundary contributing water to the simulation domain, the water contents in this region all move toward saturation. The water contents we observe in the Tshirege are near 20 '\% saturation (see for example Fig. 8). This pattern is also observed in MI('M j.1. The annomint of water potentially contributed to the systens by a poncled 


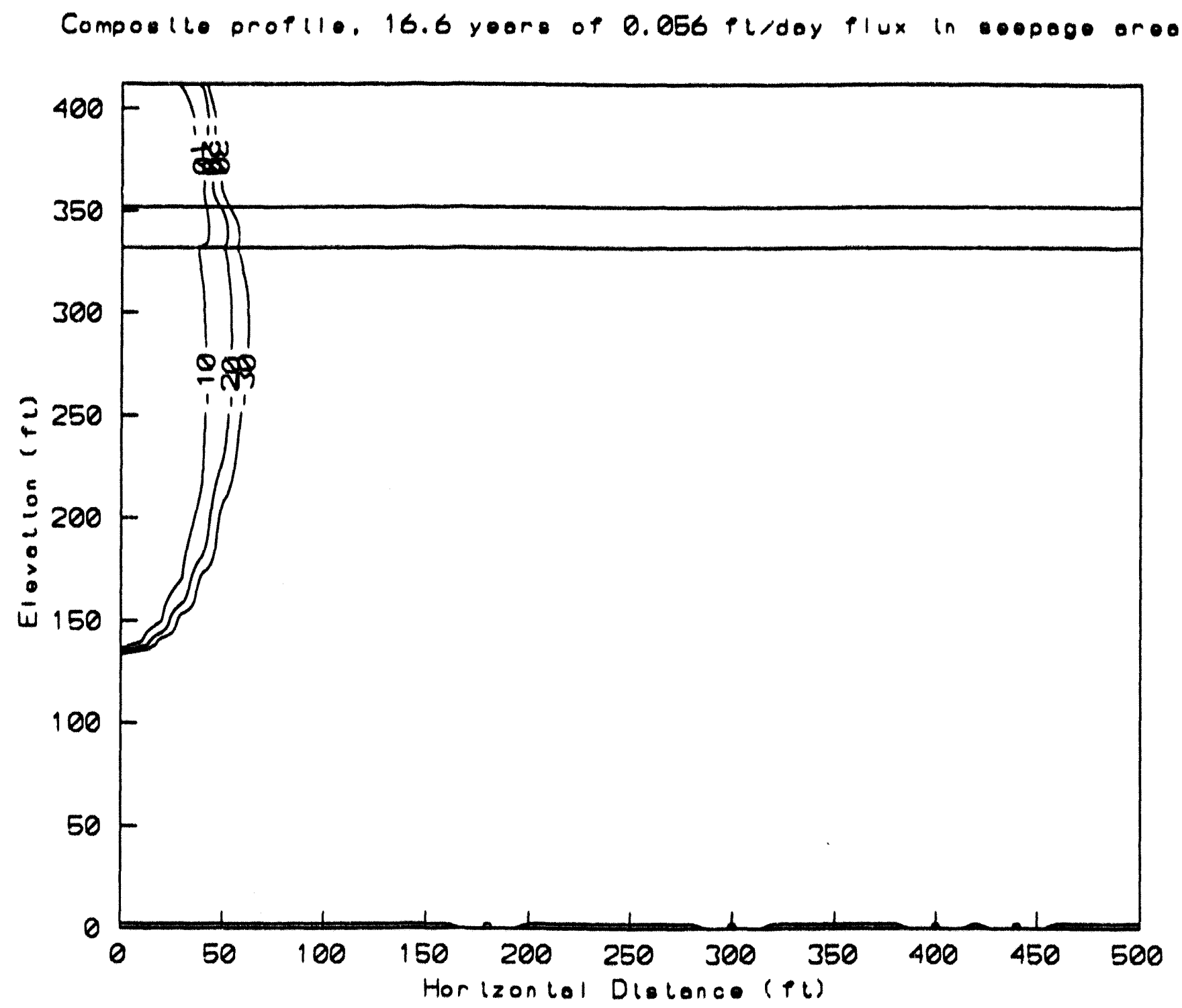

Fig. 13: UNSAT2 simulated matric potential contours (in feet) for 16.6 years of $0.056 \mathrm{ft} . / \mathrm{day}$ flux in secpage area. ('omposite cross-section consists of three matrials. 


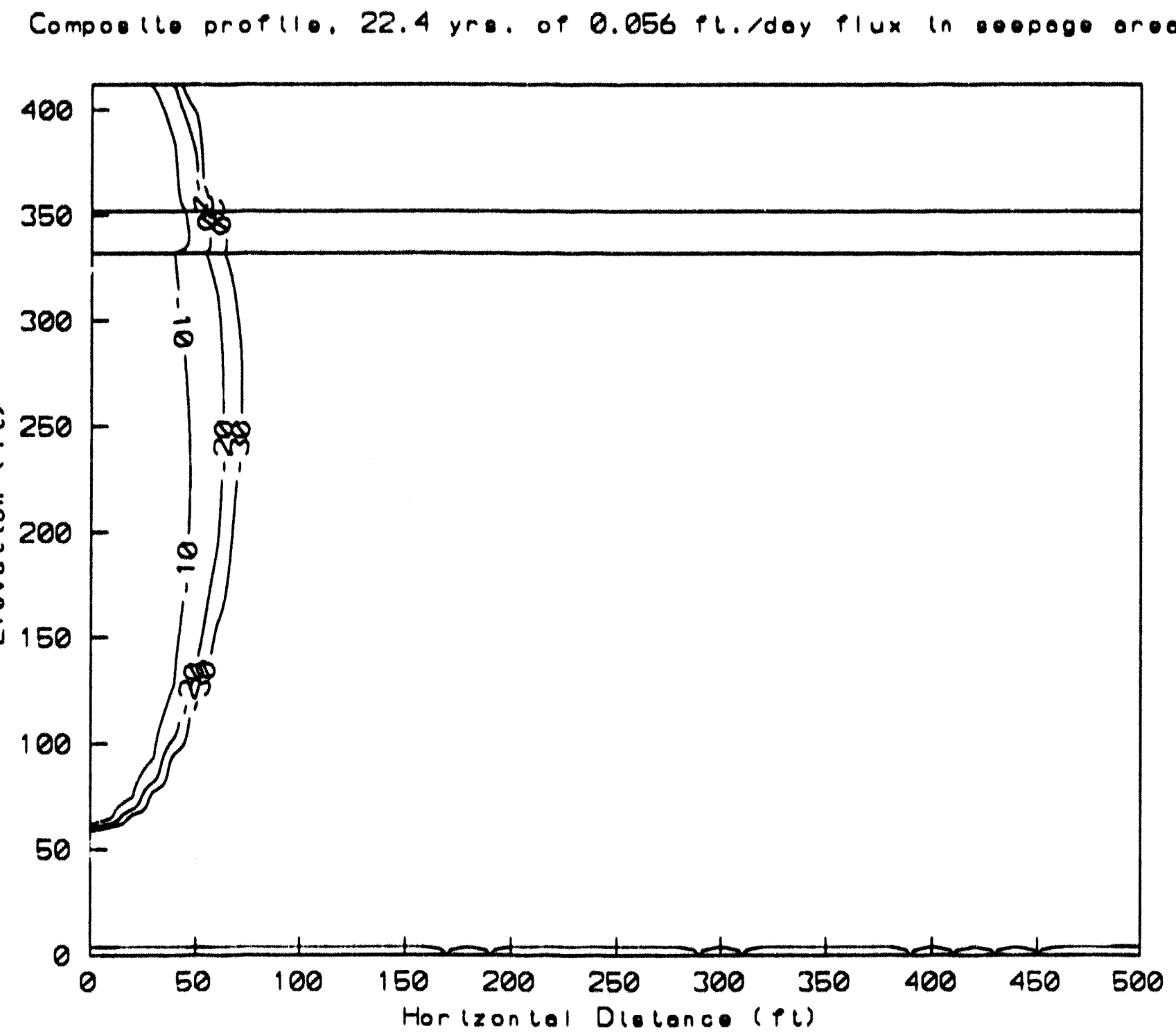

Fig. It: INSA'l'2 simmlated matric potential contours (in fert) for 22.4 rears of 0.056 ft. / lay flus in serpage areit. ('omposite cross-section consists of threer malerials. 


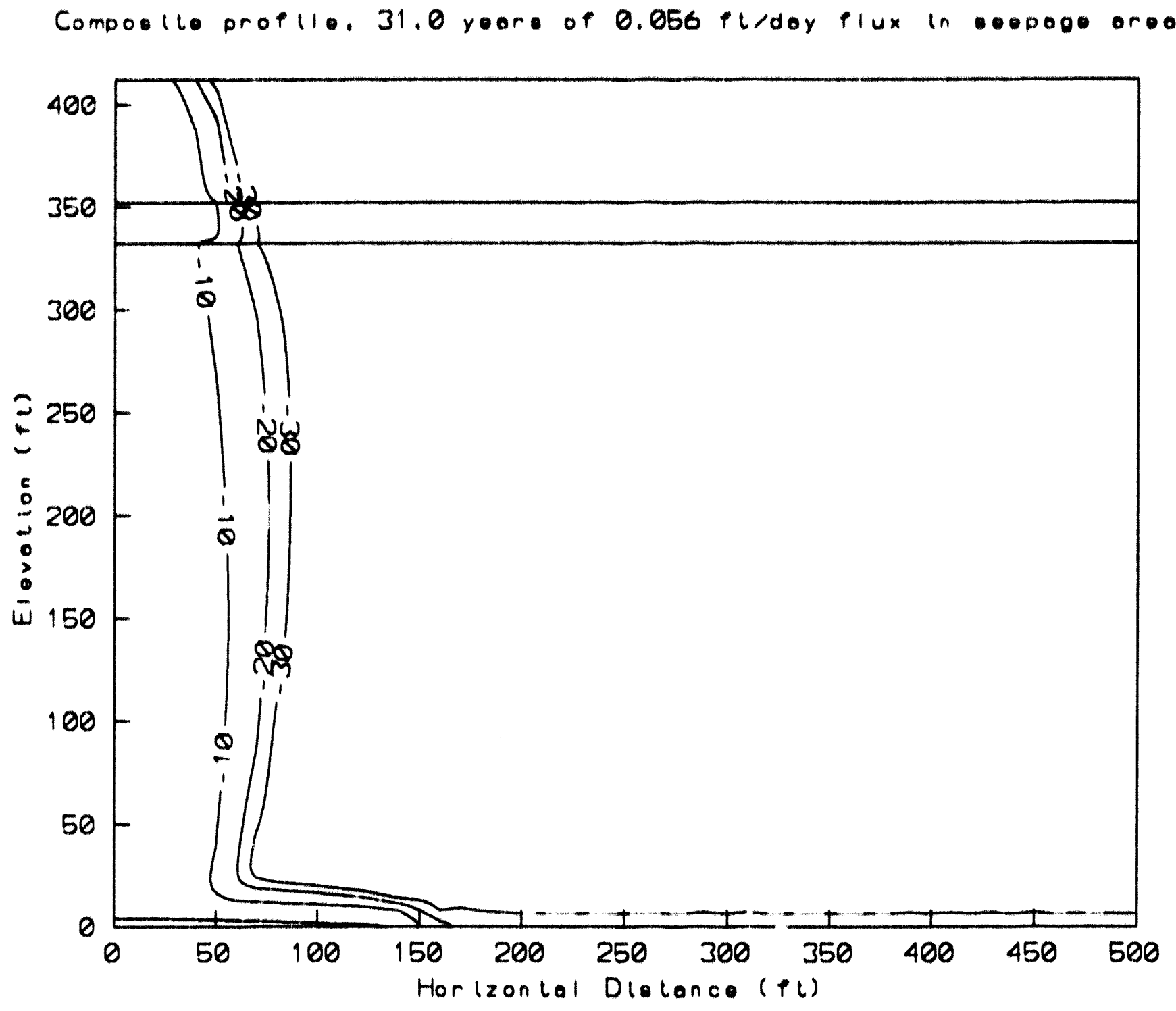

Fig. 15: "NSA'T2 simulated matric potential contours (in feet) for 31.0 yours of $0.056 \mathrm{ft}$./day flux in seepage aren. ('omposite cross-section consists of three materials. 


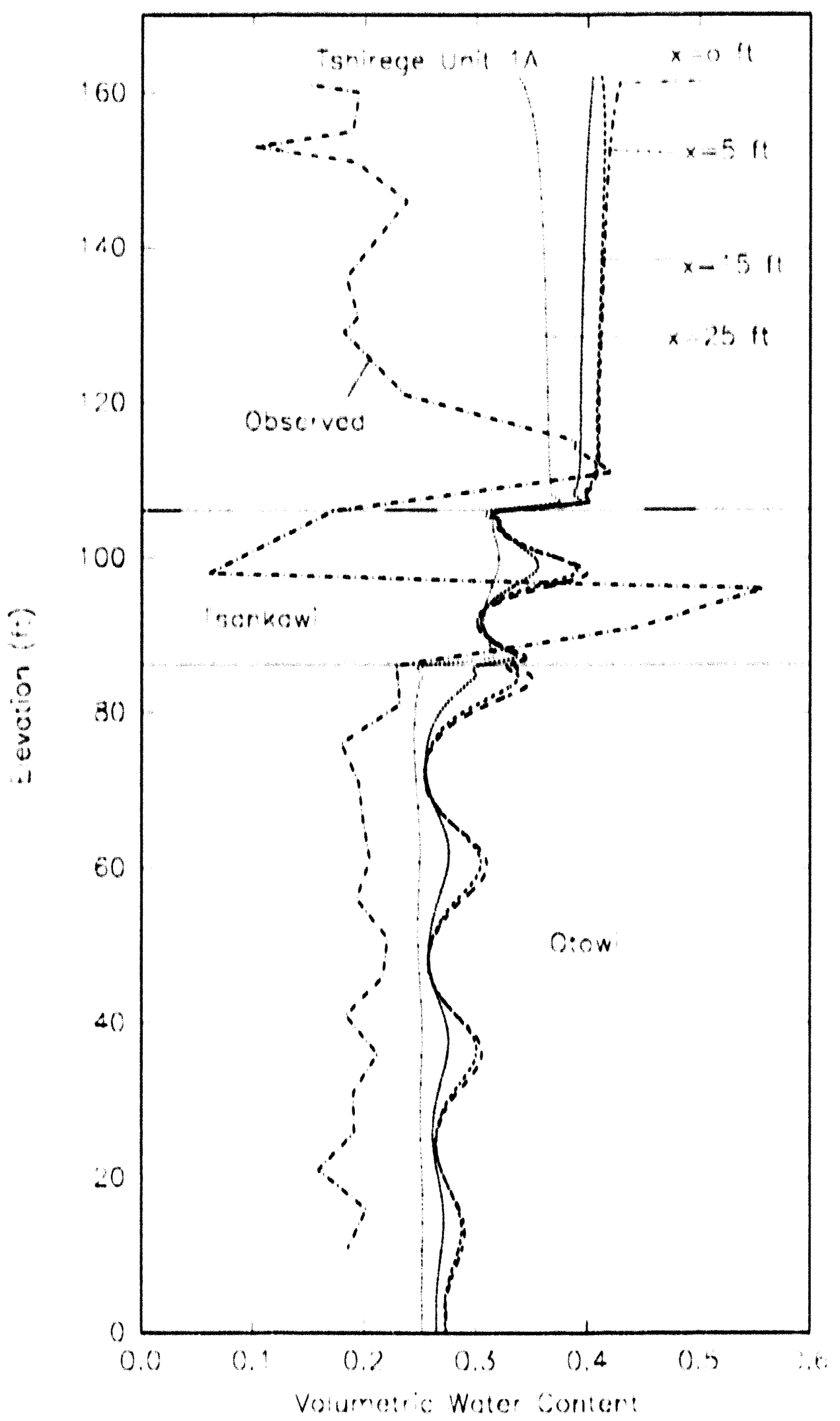

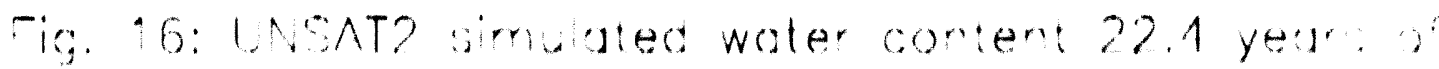

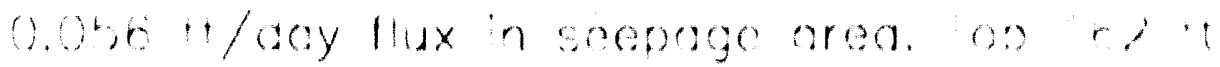

of -9 . 14, at $x-0,5,15,26$ te trom symmer axis. 


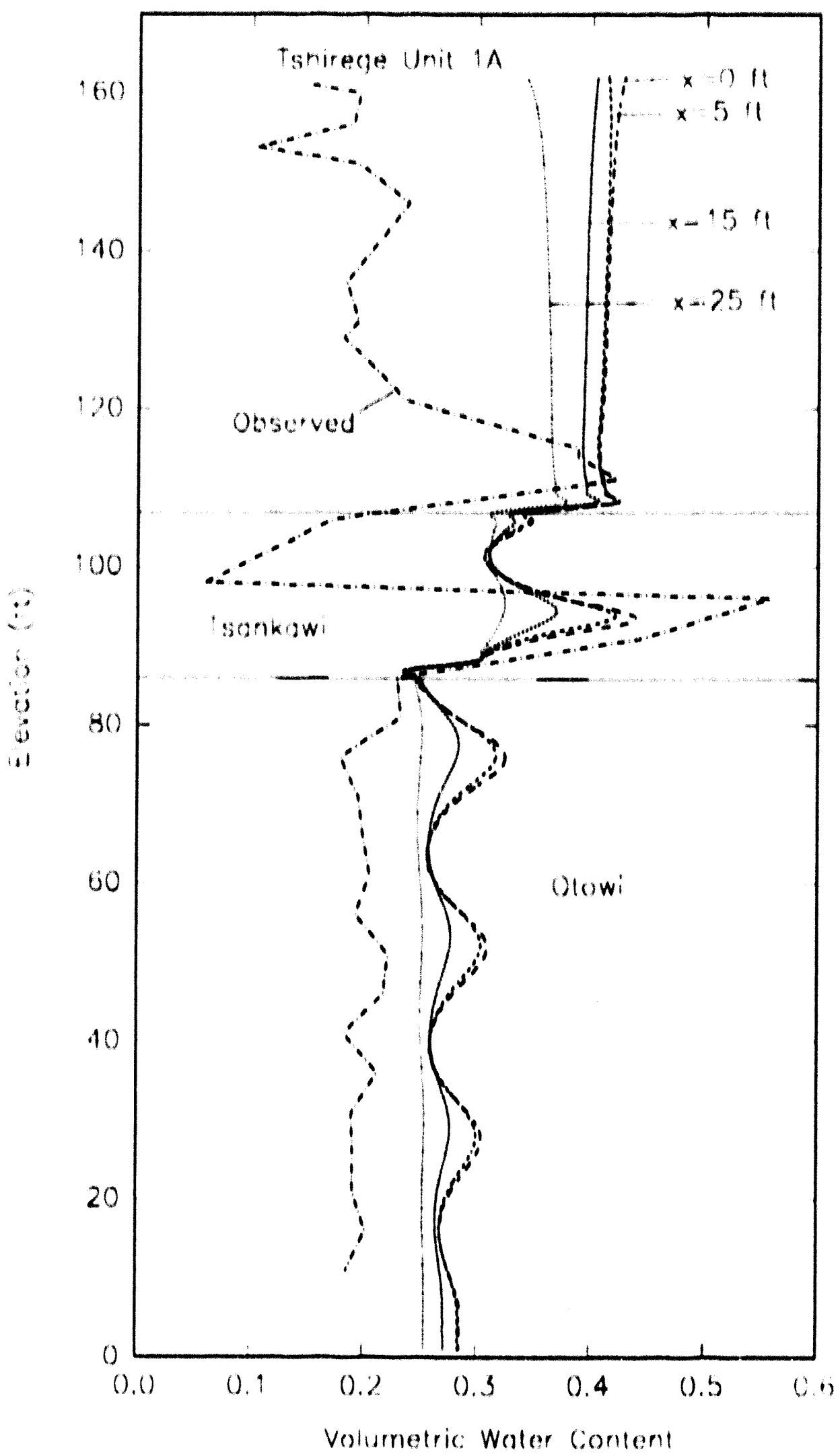

- (y. 17: UNSAI2 simulated water content with avation for 31.0 years of $0.056 \mathrm{fl} /$ doy flux in seesoge aron tor top 16? teet of lig. 15. 
head boundary condition is being reduced. One possible renson is that the highly wrathered tuff inmediately below the tuff/alluvium interface is restricting flow. The hydraulic charncteristic of this material liave not yet been evaluated and some snmpling in this region should be performed. Also, for the determination of ground ivater travel time to the regional water table, more hydranlir parameters are needed for innterial at depth. The Gunje pumice, the conglomerate, and he bnsalt ureed to be inclucled in any larger scale modeling effort.

The observed decrease in water coulent above the upper contact (through the Tshirege) conld also be the result of upward diffusion of water vapor from the 'wet' interface. The next step in unmerical simulation sliould include this plie. nomenn. either in a multi-pline analysin, or by diffusion simulation alone. The water coutent increase on each lithologic contact conld be simulated as a plannar source lor diffusion, allowing water to diffuse downward as well. A numerical solution for the diffusion menation in hydrogeologic nyatems is linted in the referenrers (Ishii, ct al.. 1080). Also. the strnta in this nyatem are not perfectly horizontal. Tilting hin simulation domnin to take the principal concluctivity off horizontul and assigning some arbitrary nuisotropy could provide more enlightening results. possible rausing ivater to flow aloug the coutacts to a grenter extent.

Votnbly absent from this annlysin is an accounting of mass. The balnuce between prescribed hux rate and cliange of water content, element by element (or cell by cell), should be evalunted. The canyon has been collecting and seeping water into the tuff for 10's of thounands of years. Water movement for this length of time call not be modeled reliably in the unsaturnted zone. Our ability to generate complex numerical computer methods is still inore sophisticnterl thun

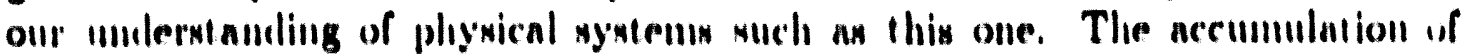
moivture on top of the two lieliologic contacts could be attributed to a muchl lowers How rale over lhis longer time period.

All evaluation of this nyatem by finite difference should be undertaken. VS'21) I (Lappnla, et. al, 108i, and Healy, 1990) is the suggested code for this purposs. Trnusport of tritiun conld then be used as an aid to understanding, an l'S'21)T is capalsle of solving the transport problem. Boundary conditions, initial conditions. molecular diffusion coefficient of tritium in tuff, and dispersivity, are emsily mnnipulated in computer simulations, which is the benefit of this type of nunlysis. 


\section{References}

Davis. L.A., and S.P. Neuman, 1983. Dorumentation and lser's (iuide: U.VSAT:S - liminaly Saturnted Flow Model. NURECi/CR.3390.

Healy. R.W.. 1090. Simulation of Solute Tmanpoit in Variably Saturaled

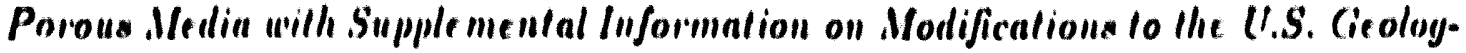
ical Surtey a Compuler Proginm I'S:DD. U.S.G.S. Water-Resources Investigations Report 90.4025 .

Isliii. A.L.. R.W. Healy, and R.G. Striegl, 1989. A Numerical Solution for the Diffusion Equation in Hydrogeologir Systems. U.S.G.S. Water - Renources Inventigations Report $39 \cdot 402 i$.

Lapponla, E.(i., R.IV. Healy, and E.P. Weeks, 108T. Documentation of Compuler Program 1'SgD to Solve the Equntions of Flund Flow in Variably Suturnted Porous Medin. U.S.G.S. Winter-Resources linventigntiona Report 83-1099.

Purtymun. W.D.. E.A. Enyart, and S.G. McLin. 1980. Hydrologic Charneteristicin of the Bundelier. Tulf us Delermined Through an Injection Will Sysalem. LANL report number LA-11511-MS.

Stoker, A.K., W.D. Purtymun, S.(i. McLin, and M.N. Mnes, 1001. E.rlınt of Sinturntion in Mortundad Canyon. LANL Buviroummental Restorntion report number LA.UR.91-1660.

van Cenuchten, M.Th., 1980. A Close-form Equation for predicting the IIydranlic Conductirity of I'nsafurated Soils. Soil Sci. Soc. Am. J., H. 802-808. 
7. Appendices 
7.1. Input files 
Input file for UNSAT2 run of Figures $5 \& 6$.

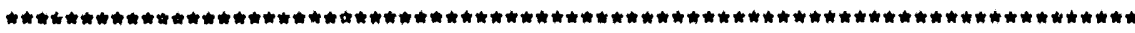

MCM-5.9A, Large Grid $(x=250, y=662$ feet $), 21$ to $y=500 \ldots$

$\begin{array}{llllllllll}12350 & 2611850 & 2 & 9 & 0 & 15 & 1 & 0 & 0 & 1\end{array}$

$\begin{array}{rrrlllll}0.601 & 70.0 & 0.0001 & 1.1 & 36525.0 & 50.0 & 100 & \\ 1 . & 1 . & & & & & & \\ .822 & .822 & 0.486 & 0.0 & 0.120 & 0.24475 & 1.58945 & 1 \\ 4.819 & 4.819 & 0.538 & 0.0 & 0.094 & 0.17953 & 1.74058 & 1 \\ 22.110 & 22.110 & 0.519 & 0.0 & 0.082 & 0.16916 & 1.92358 & 1 \\ .7937 & .7937 & 0.552 & 0.0 & 0.084 & 0.24506 & 1.86760 & 1 \\ 2.239 & 2.239 & 0.435 & 0.0 & 0.052 & 0.48219 & 1.55108 & 1 \\ 12.189 & 12.189 & 0.6465 & 0.0 & 0.198 & 0.24933 & 1.45120 & 1 \\ 5.668 & 5.669 & 0.537 & 0.0 & 0.329 & 0.15484 & 1.72981 & 1 \\ 3.118 & 3.118 & 0.4985 & 0.0 & 0.124 & 1.351178 & 1.47491 & 1 \\ 11.055 & 11.055 & 0.686 & 0.0 & 0.209 & 3.184855 & 1.34112 & 1\end{array}$

25,474

1,1

3*5 $13 * 10 \quad 6 * 15$

$250 \star 2.0 \quad 100 * 1.0 \quad 124 * 0.5$

$12350 * 0$

12324*0 5*0.0056 21*0

$7618 *-42.0468 *-48.0 \quad 338 *-33.0 \quad 130 *-26.0104 *-38.0$

$286^{*}-141.0286 *-58.0416^{*}-22.02704^{*}-35.0$

7300*1 450*2 325*3 125*4 100*5 275*6 275*7 400*8 2600*9

$11850 * 0.0$

END 
Input File for UNSAT2 run of Figure 7.

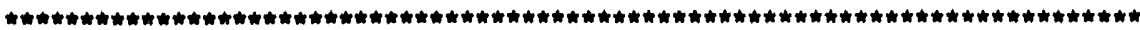

MCM-5.9A, Large Grid $(x=250, y=662$ feet $), 21$ to $y=500 \ldots$

$\begin{array}{llllllllll}12350 & 2611850 & 2 & 9 & 0 & 15 & 1 & 0 & 0 & 1\end{array}$

$\begin{array}{rrrlllll}0.001 & 70.0 & 0.0001 & 1.1 & 36525.0 & 50.0 & 100 \\ 1 . & 1 . & & & & & & \\ .822 & .822 & 0.486 & 0.0 & 0.120 & 0.24475 & 1.68945 & 1 \\ 4.819 & 4.819 & 0.538 & 0.0 & 0.094 & 0.17953 & 1.74058 & 1 \\ 22.110 & 22.110 & 0.519 & 0.0 & 0.082 & 0.16916 & 1.92358 & 1 \\ .7937 & .7937 & 0.552 & 0.0 & 0.084 & 0.24506 & 1.86760 & 1 \\ 2.239 & 2.239 & 0.435 & 0.0 & 0.052 & 0.48219 & 1.55108 & 1 \\ 12.189 & 12.189 & 0.6465 & 0.0 & 0.198 & 0.24933 & 1.45120 & 1 \\ 5.669 & 5.669 & 0.537 & 0.0 & 0.329 & 0.15484 & 1.72981 & 1 \\ 3.118 & 3.118 & 0.4985 & 0.0 & 0.124 & 1.351178 & 1.47491 & 1 \\ 11.055 & 11.055 & 0.686 & 0.0 & 0.209 & 3.184855 & 1.34112 & 1\end{array}$

25,474

1,1

$6 * 513 * 106 * 15$

$250 * 2.0 \quad 100 * 1.0 \quad 124 * 0.5$

$12350 * 0$

$12350 * 0$

$7618 *-42.0468 *-48.0338 *-33.0130 *-26.0104 *-38.0$

$286 *-141.0286 *-58.0416 *-22.02678 *-35.05 * 1.029 *-35.0$

$7300 * 1 \quad 450 * 2 \quad 325 * 3 \quad 125 * 4 \quad 100 * 5 \quad 275 * 6 \quad 275 * 7 \quad 400 * 8 \quad 2600 * 9$

$11850 * 0.0$

END 
Input File for UNSAT2 run of Flgures 8, 9, 10, 11, and 12.

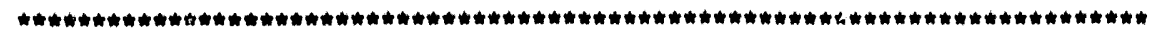

MCM 5.9A, Large orid $(x=500, y=162$ feet $)$, del $x=5^{\prime}$, del $y=0.5^{\prime}$

231285622660

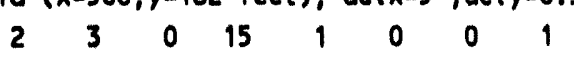

$\begin{array}{rrrrrrrr}0.01 & 25.0 & 0.001 & 1.2 & 365250.0 & 75.0 & 100 & \\ 1 . & 1 . & & & & & & \\ 2.239 & 2.239 & 0.435 & 0.0 & 0.052 & 0.48219 & 1.55108 & 1 \\ 3.690 & 3.690 & 0.478 & 0.0 & 0.150 & 0.90465 & 1.48191 & 1 \\ 0.397 & 0.397 & 0.515 & 0.0 & 0.040 & 0.35905 & 1.49131 & 1\end{array}$

55,412

1.1

$10 * 5.0 \quad 45 * 10.0$

$412 * 1.0$

23072*0 5*1 51*0

$23072 * 05 * 0.051 * 0$

$18648 *-38.01120 *-313304 *-73.05 * 1.051 *-73$

$18260 * 1 \quad 1100 * 23300 * 3$

$22660 * 0.0$

END 
Input flle for UNSAT2 run of Floures 13, 14, 15, 16, and 17 .

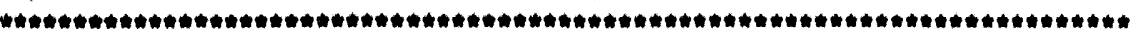

MCN 5.9A, Large orld ( $x=500, y=162$ feet), del $x=51$, dely=0.5'

$\begin{array}{llllllllll}23128 & 5622660 & 2 & 3 & 0 & 13 & 1 & 0 & 0 & 1\end{array}$

$\begin{array}{rrrrrrrr}0.01 & 25.0 & 0.001 & 1.2 & 365250.0 & 73.0 & 70 & \\ 1 . & 1 . & & & & & & \\ 2.239 & 2.239 & 0.435 & 0.0 & 0.052 & 0.48219 & 1.55108 & 1 \\ 3.690 & 3.690 & 0.478 & 0.0 & 0.150 & 0.90465 & 1.48191 & 1 \\ 0.397 & 0.397 & 0.515 & 0.0 & 0.040 & 0.35905 & 1.49131 & 1\end{array}$

55,412

1,1

$10 * 5.0 \quad 45 * 10.0$

$412 * 1.0$

23128*0

$23072 * 05 * 0.005651 * 0$

$18648 * 38.01120 *-313360 *-73$

$18260 * 1 \quad 1100 * 23300 * 3$

$22660 * 0.0$

END 
7.2. UNSAT2 Source Code 


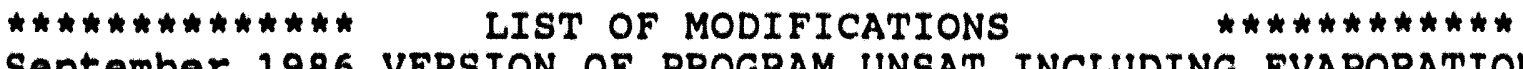 \\ September 1986 VERSION OF PROGRAM UNSAT INCLUDING EVAPORATION,
} TRANSPIRATION, AND WELL OPTIONS

spring 87: MODIFIED TO TAKE Van Genuchten ANALYTICAL EXPRESSIONS FOR THE SOIL HYDRAULIC PARAMETERS. TABULAR INFORMATION IS NOT LONGER REQUIRED

Spring 89: MODIFIED TO DISPLAY INFORMATION ABOUT TIME, TIME STEP, AND ITERATIONS. THE FREQUENCY OF PRINTOUT IN TERMS OF TIME STEP IS CONTROLED BY THE INDEX "INPR"

Spring 90:

INCLUDE ADDITIONAL SOIL HYDRAULIC PARAMETER MODELS; NOW, THE UNSATURATED SOIL PARAMETERS MAY BE REPRESENTED BY THE FOLLOWING MODELS :

\author{
IDM(I) - 1: VAN GENUCHTEN MODEL \\ - 2: EXPONENTIAL MODEL \\ - 3: GARDNER-RUSSO MODEJ \\ - 4: EXAMPLE OF USER-SPECIFIED MODEL
}

Summer 92: To port code to LANL ICN Cray Y-MP running UNICOS 6.0 .1 search for "cmike" and make suggested changes. Otherwise this version of the code will run on an IBM PC. Automat:c time stepping included. Time step is divided by two if convergence is not achleved and simulation restarts from last convergent time step.

Automatic Grid Generation for simple geometries is controlled by the variabla ICG in Group $B$

$\star \star \star \star * \star * \star * \quad$ TAPE AND MEMORY REQUIREMENTS

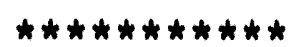

TATE 1 REQUIRES A STORAGE OF AT LEAST $8 *(100+6 * N U M N P+7 * N U M E L+$ $(2 \star M K+4 \star M P) \star I U M M A T+N D I M *(2+M A X S P)+2 \star N U M D P+N D I M P \star(4+4 \star M X C O L+2 \star M X N O D$ $1+2 \cdot(Y N O D)$ EITES

- TA: 2 ? REQUI ES A STORAGE OF AT LEAST $8 *(I J+3) * N U M N P$ BYTES.

-.- THE $S: Z E$ OF BD MUST BE AT LEAST $(I J+3) * N U M N P$

-.- THE *E OF S MUST BE AT LEAST $11 * N U M N P+7 * N U M E L+$ $+\operatorname{M} X(1, \operatorname{NSEEP}) *(2+\operatorname{MAX}(1, \operatorname{NSP}(I)))+2 \star \operatorname{MAX}(1, \operatorname{NUMEP})+\operatorname{MAX}(1, \mathrm{NPLNT})$ * $(4+4$ * $\operatorname{MA}:(1, \therefore \operatorname{COL}(\Xi))+2 * \operatorname{MAX}(1, \operatorname{NSOUR}(J))+2 * \operatorname{MAX}(1, \operatorname{NSOUR}(J)))$

---THE $3: Z E$ OF SACH ARRAY IN COMMON /MAT/ MUST BE AT LEAST NUMMAT

$\begin{array}{cl}\text { UNIT } & \text { DESCRIPTION } \\ 1 & \text { Storig the necessary information for "RESTART" runs } \\ 2 & \text { Contains the A and B matrices (scratch flie) } \\ 6 & \text { Concains general input/output information } \\ 8 & \text { Contains Time versus Cumulative Inflow into the flow domain } \\ 10 & \text { Contilins } X, Y, \text { Pressure Head, Node number and Total Head for } \\ & \text { plot:ing porpuses }\end{array}$

\section{LAST MODIFIED $06 / 29 / 1990$}

PROGRAM U2

like HED* 4 should be changed to HED* (and END and RESTAR if they are used) TFILE is deleted where it appears below.

CHARACTER IIIF LE*60, HED*4, END*4, RESTAR*4

like These array's must be dimensioned for each run.

DIMEISION BD (20000), BS (17000)

uike This line should be commented out, and the variables it contains 
hould be removed from the code. INTEGER 4 IHR, IMIN, ISEC, I 100, IHRE, IMINE, ISECE, I IOOE

mike (9) represents nine materials, and must be changed to the number f materials used COMMON /MAT/ CONS1, CONS2, C1 (9), C2 (9), SS (9), POR(9), ALPHA (9),

$\star$ $\operatorname{BETA}(9)$, WCR (9), IDM(9)

COMMON /FIX/ HED(20), INIT, MAXIT, KAT, IJ, INTEG, NSEEP

COMMON /WEL/ NB (3), NE (3), NBW, NPT, NPT1, NPB, NPB1, LW, NEP, NSW, AL, AL1,

1 QP, QA, RW, RT, ALFA

DATA END/'END '/,RESTAR/'REST'/

OPEN (1, FILE='UNS 1. DAT', STATUS = 'UNKNOWN')

OPEN $(2$, STATUS $=$ ' SCRATCH' , FORM = 'UNFORMATTED')

OPEN (6, FILE='UNSAT. OUT', STATUS = 'UNKNOWN')

OPEN (8,FILE $=$ 'UNS8 . DAT' , STATUS $=$ 'UNKNOWN')

OPEN (10, FILE= 'UNS 10.DAT', STATUS = 'UNKNOWN')

mike All reads and writes to $(*, *)$ should be removed, here and in

he rest of the code, search for them.

WRITE $(*, *)$ ' TYPE DATA FILE NAME: '

mike Delete the next two Iines and open the input flle, UNIT=15, with

standard open statement.

READ (*,' (A)') INFILE

$\operatorname{OPEN}(15$, FILE =INFILE, STATUS $=$ 'OLD')

$N E R R=0$

mike Remove all calls to GETTIM

CALL GETTIM(IHR, IMIN, ISEC, I 100)

WRITE $(6,8)$ IHR, IMIN, ISEC

8 FORMAT $\left(/ /, 5\left({ }^{\prime} *^{\prime}\right),,^{\prime}\right.$ STARTING TIME: $\left.1,2\left(I 2, \prime^{\prime}:^{\prime}\right), I 2,1 X, 5\left({ }^{\prime}{ }^{\prime}\right), / /\right)$

10 RE:D $(15,20)$ HED

20 FORMAT (2OA4)

IF (HED(1) . EQ. END) THEN

CALL GETTIM(IHRE, IMINE, ISECE, I IOOE)

WRITE $(6,19)$ IHRE, IMINE, ISECE

CPU $=3600 . *($ IHRE-IHR) +60.0* (IMINE-IMIN) +FLOAT (ISECE-ISEC) +

$\&$ $0.01 *(I 100 E-I 100)$

WRITE $(*, 21)$ CPU

WRITE $(6,21)$ CPU

19 FOIMAT $\left(/ /, 5\left(\prime^{\prime}{ }^{\prime}\right),{ }^{\prime}\right.$ ENDING TIME: ', $\left.2\left(\mathrm{I} 2,,^{\prime} \mathbf{\prime}^{\prime}\right), \mathrm{I} 2,1 \mathrm{X}, 5\left({ }^{\prime} \star^{\prime}\right), / /\right)$

21 FORMAT(' $* \star \star$ CPU TIME $=\prime$, E13.5,' SECONDS $* \star * \prime \prime)$ ST JP

ENDIF

IF (HED(1) .EQ. RESTAR) GO TO 100

READ (15, 30) NUMNP, IJ', NUMEL, KAT, NUMMAT, INIT, MAXIT, INTEG, NSEEP, MAXS, \&IGG

READ ( 15,30$)$ NBW, NPB, NPT, NEP, LW, NUMEP, NPLNT, MXCOL, MXNOD

30 FORMAT (16I5)

NU:IDP = NUMEP

IF (INUMDP . LT. 1) NUMDP=1

NDIMP $=$ NPLNT

IF (NPLNT . GT. O) GO TO 40

NDIMP $=1$

$M: C O L=1$

M:IIOD $=1$

$40 \mathrm{~N} T \mathrm{~A} \cdot \mathrm{PE}=0$

NUMRES $=0$

$M R X S P=1$

NDIM $=1$

IF (IISEEP . LT. 1) GO TO 50

NDIM $=$ NSEEP

MAXSP $=$ MAXS

50 MEALD $=I J+2$ 
$80 M 2=1+M B A N D * N U M N P$

$N 2=1+N U M N P$

$N 3=N 2+N U M N P$

N4 $=$ N3+NUMNP

N5 $=$ N4 + NUMNP

N6 $=$ N5 + NUMNP

N7 $=$ N6 + NUMNP

$N 8=N 7+N U M N P$

$N 9=N 8+N U M N P$

N1O=N9+NUMNP

N11-N10+NUMNP

N12 $-N 11+5 * N U M E L$

N13-N12+NUMEL

N14 $=$ N13+NUMEL

N2 $1=N 14+M A X S P * N D I M$

N22 $=$ N21+NDIM

N23 $=$ N22 +NDIM

$N 24=N 23+N U M D P$

$N 25=N 24+N U M D P$

N2 $6=N 25+$ NDIMP

$N 27=N 26+N D I M P$

N28 $=$ N27+NDIMP

$N 29=N 28+N D I M P$

$N 30=N 29+M X C O L * N D I M P$

N3 $1=N 30+M X C O L * N D I M P$

$N 32-N 31+M X C O L * N D I M P$

N33 $=1132+M X C O L * N D I M P$

$N 34=1133+M X N O D * N D I M P$

$N 35=N 34+M X N O D * N D I M P$

N36 $=135+N U M N P$

If ( $H E D(1)$. ne. RESTAR) then

TP1 $=8 *(100+6 *$ NUMNP + 7*NUMEL+NDIM* $(2+$ MAXSP $)+$

$\&$ $2 * N U M D P+N D I M P *(4+4 * M X C O L+2 * M X N O D)+2 * M X N O D)$

TF2 $=4 *(I J+3) \star N U M N P$

WRITE $(6,1) M 2, N 36+$ NUMNP

1 FOFMAT(' ','STORAGE CHECK' $/ /$ ' THE DIMENSION OF BD SHOULD BE ',

1 'GREATER THAN',I10/,' THE DIMENSION OF BS SHOULD BE GREATER ',

2 'THAN', I10/)

UR: $\triangle E(6,2)$ TP1/1000,TP2/1000

2 FC:IAT (5X,'UNS 1.DAT REQUIRES: ', $F 7.1, ' \mathrm{~Kb}, /$

$\&$

ENDI:

5X,'UNS2. DAT REQUIRES: ',F7.1,' $\mathrm{Kb}, 1 /$ )

90 CALL FEM (BD(1),BD(M2),BS(1),BS(N2),BS(N3),BS(N4),BS (N5), BS (N6),

$1 B S(N 7), B S(N 8), B S(N 9), B S(N 10), B S(N 11), B S(N 12), B S(N 13), B S(N 14)$,

$2 \mathrm{BS}(1121), \mathrm{BS}(\mathrm{N22}), \mathrm{BS}(\mathrm{N} 23), \mathrm{BS}(\mathrm{N} 24), \mathrm{BS}(\mathrm{N} 25), \mathrm{BS}(\mathrm{N} 26), \mathrm{BS}$ (N27), BS (N28), $3 \mathrm{BS}(1129), \mathrm{BS}(\mathrm{N} 30), \mathrm{BS}(\mathrm{N} 31), \mathrm{BS}(\mathrm{N} 32), \mathrm{BS}(\mathrm{N} 33), \mathrm{BS}(\mathrm{N} 34), \mathrm{BS}(\mathrm{N} 35), \mathrm{BS}(\mathrm{N} 36)$, 4NUYIIP, MBAND, NUMEL, NUMMAT, MK, MP, NERR, NDIM, MAXSP, NTAPE,

5NUMRES, NUMDP, NUMEP, NPLNT, NDIMP, MXCOL, MXNOD, IGG)

IF (I:ERR .GT. O) THEN

CALL GETTIM(IHRE, IMINE, ISECE, I LOOE)

$C P U=3600 . *($ IHRE - IHR $)+60.0 *$ (IMINE-IMIN $)+$ FLOAT (ISECE-ISEC $)+$

$\&$ $0.01 *(I 100 E-I 100)$

WRITE $(6,19)$ IHRE, IMINE, ISECE

WRITE $(*, 21)$ CPU

WRITE $(6,21) \quad C P U$

STOP

ENDIF

GO TO 10

100 REWIND 1 
READ $(1, *)$ NUMNP, MBAND, NUMEL, NUMMAT, MAXSP, NDIM, NSEEP, NUMDP, 1NUMEP, NPLNT, NDIMP, MXCOL, MXNOD

GO TO $B O$

END

SUBROUTINE FEM ( $A, B, K O D E, Q, P, P 1, T, D, C R, C, X, Y, K X$, SANG, CANG, INP, NSP, KODES, WIDTH, BTP, NCOL, NSOUR, PW, TPOT, NRB, NRT, $W$, PR, RDF, 2MTR, SAVE, CC, NUMNP, MBAND, NUMEL, NUMMAT , MK, MP, NERR, NDIM, JMAXSP, NTAPE, NUMRES, NUMDP, NUMEP, NPLNT, NDIMP, MXCOL, MXNOD, IGG)

DIMENSION A (MBAND, NUMNP), B (NUMNP), KODE (NUMNP), Q (NUMNP), P (NUMNP), 1 P1 (NUMNP), T (NUMNP) , D (NUMNP), CR (NUMNP) , C (NUMNP), X (NUMNP), $2 Y$ (NUMNP) , KX (NUMEL, 5), SANG (NUMEL), CANG (NUMEL), 3NP (NDIM, MAXSP) , NSP(NDIM) , KODES (NDIM) , WIDTH (NUMDP) , BTP (NUMDP), 4NCOL (NDIMP) , NSOUR (NDIMP) , PW (NDIMP) , TPOT (NDIMP) , NRB (MXCOL, NDIMP), 5NRT (MXCOL, NDIMP) , RDF (MXNOD, NDIMP) , MTR (MXNOD, NDIMP) ,W (MXCOL, NDIMP), 6PR (MXCOL, NDIMP), SAVE ( 2 , MXNOD), CC (NUMNP)

COMMON /MAT/ CONS1, CONS2, C1 (9), C2 (9), SS (9), POR(9), ALPHA (9),

$+$ $\operatorname{BETA}(9)$, WCR (9), IDM (9)

COMMON /FIX/ HED (20), INIT, MAXIT, KAT, IJ, INTEG, NSEEP COMMON /WEL/ NB(3), NE (3), NBW, NPT, NPT1, NPB, NPB1, LW, NEP, NSW, AL, ALI,

1 QP, QA, RW, RT, ALFA

DATA RESTAR/4HREST/

EPSLON 0 .

IF (HED(1) EQ, RESTAR) GO TO 580

- --READ SEEPAGE FACE INFORMATION

IF (NSEEP . LT. 1) GO TO 30

IF (MAXIT .LT, 4) MAXIT=4

DO $20 I=1$, NSEEP

READ $(15,10)$ NSP(I), KODES (I)

10 FORMAT (16I5)

NS $=1: 3 P$ (I)

$\operatorname{READ}(15,10) \quad(N P(I, J), J=1, N S)$

20 CONTINUE

- --READ POTENTIAL SURFACE FLUX INFORMATION

30 IF (NUMEP. LT. 1) GO TO 50

READ $(15,91)$ EI, PL, BTPI

$\operatorname{READ}(15,91) \quad$ (WIDTH (I), I = 1, NUMEP)

DO $\rightarrow O I=1$, NUMEP

$\operatorname{BTP}(I)=B T P I$

40 CCNII:UUE

$----R E A D$ ?LANT INFORMATION

50 IF (NPLNT . LT. 1) GO TO 70

$\operatorname{READ}(15,10) \quad(\operatorname{NCOL}(J), N S O U R(J), J=1, N P L N T)$

READ $(15,91)$ (PW(J), TPOT $(J), J=1, N P L N T)$

DO $60 \mathrm{~J}=1$, INPLNT

$N C J=1 \operatorname{COL}(J)$

NSJ $=$ IISOUR (E)

$\operatorname{REiD}(15,91) \quad(W(I, J), I=1, N C J)$

$\operatorname{READ}(15,10) \quad(\mathrm{NRB}(I, J), \operatorname{NRT}(I, J), I=1, N C J)$

NSJ $1=\mathrm{NSJ}+1$

$\operatorname{READ}(15,9:) \quad(\operatorname{RDF}(N, J), N=1, N S J 1)$

$\operatorname{READ}(15,10) \quad(\operatorname{MTR}(N, J), N=1, N S J)$

60 CONTINUE

-D--RLAD WELLBORE INFORMATION

$70 \quad A L=0$.

$Q A=0$.

IF ( HBW .L.?. 1) GO TO 80

$N S W=\| P T-N P B$

$\mathrm{NPB}]=\mathrm{NPB}+1$

NVT: : $:(P T-1$

$\operatorname{RERD}(15,10) \quad(N B(I), I=1, N B W),(N E(I), I=1, N E P)$ 
READ $(25,91)$ RW, RT, QP, AL, ALFA

IF (ALFA . LE. 0.) ALFA $=.8$

$A L I=A L$

GENERAL INFORMATION

80 READ $(15,90)$ DT, DTMAX, DTMIN, DMUL, TMAX, TOL, INPR

90 FORMAT $(6 E 10,3, I 5)$

WRITE $(6,92)$ DT, DTMAX, DTMIN, DMUL, TMAX, TOL, INPR

92 FORMAT(15X,' INITIAL TIME INTERVAL--- $=\prime, E 12.5,1$

2 15X, 'MAXIMUM TIME INTERVAL--.- $=\prime, E 25.5,1$

3 15X,'MINIMUM TIME INTERVAL-- - -1, E15.5,1

4 15X,'TIME MULTIPLIER-..-

5 15X, 'MAXIMUM SIMULATION TIME-- $-1,515.5,1$

6 15X, 'MAXIMUM ITERATION ERROR-- $=1$, E15.5,

2 15X,'PRINT OUT EVERY',I5,' TIME STEPS'//

IF (KAT . EQ. 0) WRITE $(6,100)$

IF (KAT .EQ. 1) WRITE $(6,110)$

IF (KAT .EQ. 2) WRITE $(6,120)$

IF (KAT .EQ. 3) WRITE $(6,130)$

IF (KAT .EQ. 3) KAT=1

100 FORMAT (15X,22H HORIZONTAL PLANE FLOW)

110 FORUAT (15X,18H AXISYMMETRIC FLOW)

120 FORMAT (15X,20H VERTICAL PLANE FLOW)

130 FORMAT (15X,54H AXISYMMETRIC FLOW TO A WELL WITH PRESCRIBED DISCHA

IRGE//)

IF (INTEC . EQ. 1) WRITE $(6,131)$

IF (INTEO .EO. 2) WRITE $(6,132)$

131 FORIAT (15X," BACKWARD DIFFERENCE SCHEME $\%$

132 FORMAT (15\%,' TIME CENTERED SCHEME $/ / 1)$

WRITE $(6,140)$ HED, NUMNP, IJ, NUMEL, NUMAMT, MAXIT

140 FCiULiT(5X,20A4, //, 14X, 3OH NUMBER OF NODAL POINTS--..-- , I4/

$114 X$, JOH MAX NODES IN A TRNSVRS LINE- -, I4/

$214 X, 3$ OH NUMBER OF ELEMENTS--..--,$-- 14 /$

$314 \times, 3$ OH NUMBER OF MATERIALS--.-n-m, I4/

$414 X, J O H$ MAX NUMBER OF ITERATIONS--.-., I4///1)

IF (NBW .LT. 1) GO TO 160

WR $[\because:(6,150)$ NPB, NPT, RW, RT, AL

150 FOULAT (22H BOTTOM NODE OF WELL,$- I 4 /$

1

2

$22 \mathrm{H}$ TOP NODE OF WELL--- - , I $4 /$

22H RADIUS OF WELL-..- - E11.3/

2:H RADIUS OF TUBING---,$- E 11.3 /$

$22 \mathrm{H}$ INITIAL WATER LEVEL,$- E 11.3 / / / 1$

$A A=.5 *(R W \star R W-R T \star R T)$

$\mathrm{RW}=\mathrm{MA}$

160 IF (IIPLNT. LT. 1) GO TO 200

DO $190 \mathrm{~J}=1$, NPLNT

$N C J=N \operatorname{COL}(J)$

NSJ $=N S O U R(J)$

NSJ $1=N S J+1$

WRITE $(6,170) J, \operatorname{PW}(J), \quad(N R B(I, J), N R T(I, J), I=1, N C J)$

170 FORMAT $(/ / / / 21 H$ INPUT DATA FOR PLANT, I3 $/ / / 23 H$ WILTING PRESSURE IHEAD $=, 813.5 / / 44 \mathrm{H}$ LIST OF BOTTOM AND TOP NODES IN ROOT $2 O N E-/ /$

$210(2 I 5,3 X))$

WRITE $(6,180) \quad(\operatorname{RDF}(N, J), N=1, N S J 1)$

180 FORMAT (/// BOH ROOT DISTRIBUTION FUNCTION AT EACH NODE IN ROOT 20 INE, STARTING AT BOTTOM NODE -// 10(E13.5))

190 CONTINUE

--- READ AND GENERATE MATERIAL INFORMATION

200 CALL MATIN (NUMMAT)

-

IF (IGG.NE.U) TIIEN 
CALL SGRID(KODE, Q, P, P1, X, Y, WIDTH, NUMNP, INIT, BTPI , EI , KX, SANO,

4

\section{ELSE} NUMDP, CANG, NUMEL)

CALL NPIN (KODE, $Q, P, P 1, X, X, W I D T H$, NUMDP, NUMNP, INIT, NERR, BTPI, EI) ENDIF IF (NERR , GT. O) RETURN

INITIALIZE PLANT BOURCES

IF (NPLNT. LT. 1) 60 TO 220

DO $210 \mathrm{~J}=1$, NPLNT

CALL TRANSP ( $Q, P, P 1, T, C R, Y, N C O L, N S O U R, P W, T P O T$,

1NRB, NRT, W, PR, RDF, MTR, SAVE, NUMNP, NUMMAT, NPLNT, NDIMP,

2MXCOL, MXNOD, J)

210 CONTINUE

- - -RELD AND GENERATE ELEMENT INFORMATION

220 IF (IOQ.EQ.0) CALL MAFILL (KX, SANO, CANG, NUMEL)

- - - SETUP FOR TIME INTEGRATION

$L A=1$

TIMEmDT

OTOT=0.

ITER $=0$

$I T: T=0$

write (*,*)' Input data has been read 1 ,

INCP $=0$

230 WRITE $(*, 240)$ HED, TIME, LA, DT

240 FOr LAT $(/ / / 15 X, 20 A 4 / / 10 X, 6$ HTIME $=$, E13.5,3X, 12HTIME STEP $\approx$, I4,

(2X, IHDT $=, 213.5 / / 1$

EPE LN1 1 1. 0E28

EPE $112=1,0 E: 08$

EPE $\angle O N=1$. OE 28

PEI TURB WATER LEVEL IN WELL

IF (NBW.LT. 1) GO TO 250

CALL WELBOR (KODE, $Q, P, Y, N U M N P, D T$ )

GEVERATE TERMS OF MATRIX EQUATION

250 CALL RESET (I:ODE, A, B, Q, P, PI T , D, CR, C, $X, Y, K X$, SANG, CANG,

INUI::IP, MBAID, NUMEL, NUMMAT, M, KAT, LA, DT, DT1, ITER, INTEG)

---MOEIFY FCR CONSTANT PRESSURE HEAD NODES

CAL: CON :P (A, B, KODE, P, NUMNP, MBAND)

SOLVE BY GAUSS ELIMINATION

CA S SOLVE (A, D, NUMNP, MBAND)

DO $260 I=1$, NUMNP

$P(I)-B(I)$

260 COITINUE

---DETERMINE BOUNDARY FLUXES

CALL FIXQ (A, B, KODE, Q, P, P1, D, NUMNP, MBAND, DT, LA, INTEG)

-DOITERATE TO IMPROVE SOLUTION

270 IF (MAXIT. . LT. 1) GO TO 460

ITER $I T E R+1$

MCDIFY CONDITIONS ON WELLBORE

IF (NBW . GT. O) CALL WELBOR (KODE, Q, P, Y, NUMNP, DT)

- - MODIFY CONDITIONS ON SEEPAGE FACES

IF (NSEEP . EQ. O) GO TO 320

DO $310 \quad I=1$, NSEEP

ICIIECK $=0$

$N S=N S P$ ( I )

DO $300 \mathrm{~J}=1$, NS

$\operatorname{N=NP}(I, J)$

IF (KODE (N) .NE. -2) GO TO 280

IF (P(N) .LT. 0.) ICHECK $=1$

IF (ICHECK .GT. O) GO TO 300

$\operatorname{KODE}(N)=2$ 


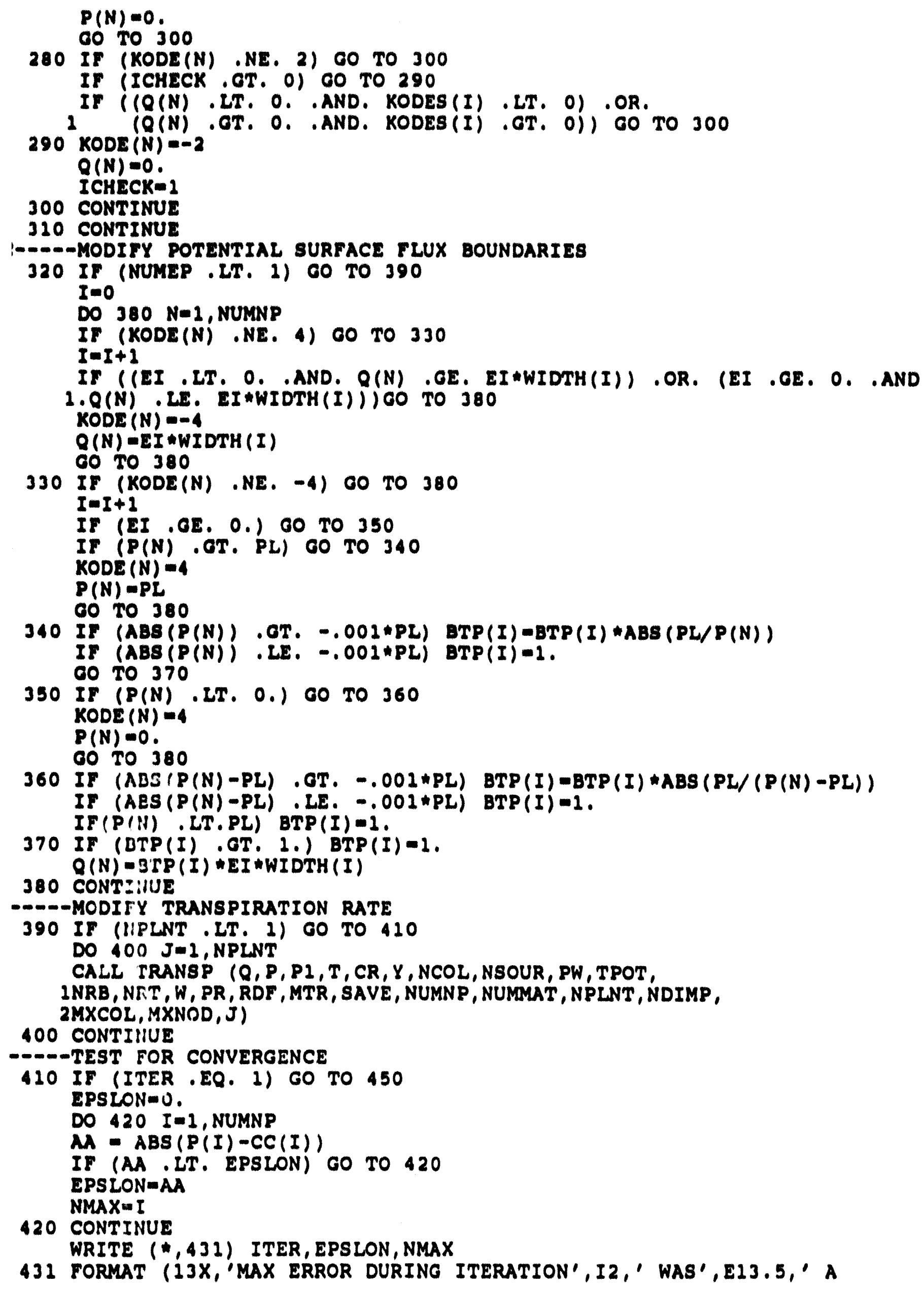


1T NODE', I4)

IF (NBW , GT. 0) WRITE (6, 440) AL, QA

440 FORMAT (/24H WATER LEVEL IN WELL WAS, E13,5,29H. DISCHARGE FROM AQ IUIFER WAS, E13.5)

IF (EPSLON , LE, TOL .OR, ITER , GE, MAXIT , OR, EPSLN2, LE. EPSLON)

160 TO 460

450 DO $455 I=1$, NUMNP

$455 \quad C C(I)=P(I)$

EPSLN2-EPSLN1

EPSLN1-EPSLON

CO TO 250

-PRINT RESULTS

OTOT IS UPDATED AND PRINTED ONLY IF THE CURRENT ITER CONVERGED

460 IF (EPSLON. LE. TOL. OR. (ITER. LT. MAXIT. AND. EPSLON. LT. EPSLN2)) THEN

DO $470 \mathrm{~N}=1$, NUMNP

QTOT-OTOT $+Q(N) \star D T$

470 CONTINUE

WRITE $(8,485)$ TIME, QTOT

485 FORMAT $(5 \times, 2 F 12.5)$

ENDIF

IF (NBW .GT. O)WRITE $(6,490)$ QP, AL

490 FORMAT (//22H DISCHARGE FROM WELL,$- E 13.5 /$

1

$22 H$ WATER LEVEL IN WELL,$- E 13.5 / 1$

IF (NUMEP , CT. O) WRITE $(6,500)$ EI,PL

500 FORMAT (//25H POTENTIAL SURFACE FLUX - E13.5/

1

32H MINIMUM SURFACE PRESSURE HEAD $=, E 13.5 / 1$

IF (NPLNT . LT. 1) GO TO 530

DO $520 \mathrm{~J}=1, \mathrm{NPLNT}$

$N C J=N C O L(J)$

WRITE $(6,510) J, T P O T(J), \quad(P R(I, J), I=1, N C J)$

510 TORMAT (//39H POTENTIAL TRANSPIRATION RATE FOR PLANT, I3, 2H =,E13.

15// 51H PRESSURE HEADS IN ROOTS, FROM LEFT TO RIGHT, ARE-//10(E13.

25))

320 CONTINUE

530 CONTINUE

INDP - INDP + 1

---DRINTS NODE INFORMATION EVERY 'INPR' TIMES

IF (INDP.EQ.INPR, OR . LA.EQ.1. OR ,ABS (TIME-TMAX) . LE . 0.001*DT) THEN WRITE $(6,240)$ HED, TTME, LA, DT

WRITE $(6,430)$ ITER, EPSLON, NMAX

430 FORMAT (49H MAXIMUM CHANGE IN PRESSURE HEAD DURING ITERATION, I3,

$14 H$ WAS, E13,5, 8H AT NODE, I5)

WRITE $(6,480)$ QTOT

480 FORMAT $(/ / 35 \mathrm{H}$ CUMULATIVE INFLOW INTO SYSTEM IS $=, 513.5)$

CALL PRINTO (Q,P, $Y, N U M N P, K A T)$

CALL MOIST ( $P, P 1, T, C R, K X, N U M N P, N U M E L, N U M M A T)$

ENDIF INDP - 0

SET UP NEW TIME STEP

LAMLA+ 1

IF (EPSLON ,LE. TOL .OR. (ITER . LT. MAXIT.AND. EPSLON .LT. EPSLN2))

160 TO 540

----IF CONVERGENCE IS NOT ACHIEVED: LAST DT IS DIVIDED BY TWO AND

--.THE SIMULATION CONTINUES FROM THE LAST CONVERGENT TIME STEP

$D T=D T / 2.0$

IF (DT, GT , DTMIN) THEN

WRITE $(6,534) \mathrm{LA}-1$

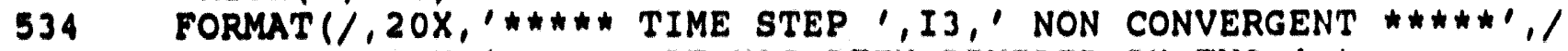

WRITE $(*, 535)$ DT HAS BEEN DIVIDED BY TWO ' 
535 FORMAT $(/, 20 x, ' \star \star \star \star \star$ NON CONVERGENT TIME STEP $* \star \star \star \star \prime, / /$ - 20X,' LAST TIME STEP HAS BEEN DIVIDED BY TWO ' )

ALI=ALLCI

TIME-TLCI

DO $536 I=1$, NUMNP

536 CONTINUE

$$
P(I)=P 1(I)
$$

\section{GOTO 555}

ELSE

$D T=D T \star 2.0$

ENDIF

NUMRES $=0$

$N E R R=1$

WRITE $(*, 538)$

WRITE $(6,538)$

538 FORMAT $(/, 10 X, 1 * * \star * \star$ SOLUTION DOES NOT CONVERGE $* \star * \star * \prime, /)$

ITIT-ITIT+ITER

60 TO 560

- - SAVES THE TIME AND WELL LEVEL OF THE LAST CONVERGENT TIME

- - - STEP INTO TLCI AND ALLCI RESPECTIVELY

540 TLCI-TIME

ALLCT $=A L$

DT1 $=D T$

$A L I=A L$

IF (ABS (TIME-TMAX) .LE. .001*DT) GO TO 560

IF (DT .IT. DTMAX. AND. ITER.LT.7) DT=DMUL*DT

550 IF (DT . GT. DTMAX) DT=DTMAX

IF ((TIME+DT) . GT. TMAX .OR. ABS (TMAX-TIME-DT) , LT. .2\#DT) DT=TMAX

\section{1 -TIME}

555 TIME - TIME+DT

ITIT-ITIT+ITER

$I T E R=0$

GO TO 230

- - DUMP ON TAPE

560 NUMRES - NUMRES - 1

WRITE $(6,551)$ ITIT

WRITE $(\star, 561)$ ITIT

561 FORMAT $(/, 15 X$, 'TOTAL NUMBER OF ITERATIONS $=\prime, I 5, /)$

IF (IIUMRES . GE. O) GO TO 590

IF (NTAPE .GT. O) GO TO 570

REWIND 1

WRITE $(1, \star)$ NUMNP, MBAND, NUMEL, NUMMAT, MAXSP, NDIM, NSEEP, NUMDP, INUMEP, NPLNT, NDIMP, MXCOL, MXNOD

570 WRITE $(1, *)$ KODE, $Q, P, P 1, X, Y, K X$, SANG, CANG, NP, NSP,

1KODES, WIDTH, BTP, NCOL, NSOUR, PW, TPOT, NRB, NRT, W, RDF, MTR, CONS1, CONS2,

2C1, C2, SS, POR, LA, ITER, DT, TIME, DT1 , KAT, INTEG, NE, NB,

3NPT, NPT1, NPB, NPB1, NBW, LW, NEP, NSW, AL, AL1 , QP, QA, RW, QTOT, PR,

4WCR, ALPHA, BETA, IDM

LAG = LA - I

WRITE $(10,571)$ LAG, TIME, DT, QTOT

571 FORMAT (2X,'TIME STEP NO. $=1, I 5, /$,

$12 X$, TOTAL TTME $=1$, E $10.5,1$,

$22 X, '$ TIME INTERVAL -, E10.5,,

$32 X, '$ CUMULATIVE INFLOW INTO THE SYSTEM $=1, E 12.5,1)$

WRITE $(10,574)$

574 FORMAT $(5 X, ' \quad X$
DO $573 I=1$, NUMNP

$D U M=Y(I)+P(I)$

WRITE $(10,572) X(I), Y(I), P(I), I$, DUM 
573 CONTINUE

IF (NTAPE . GT. O) RETURN

NTAPE $=1$

GO TO 570

-----RESTART FROM TAPE

580 READ $(15,10)$ NTAPE, NUMRES

READ $(1, *)$ KODE , $Q, P, P 1, X, Y, K X, S A N G, C A N G, N P, N S P$,

1KODES, WIDTH, BTP, NCOL, NSOUR, PW, TPOT, NRB, NRT, W, RDF , MTR, CONS1, CONS2, $2 C 1, C 2$, SS, POR, LA, ITER, DT, TIME, DT1, KAT, INTEG, NE, NB,

3NPT, NPT1, NPB, NPB1, NBW, LW, NEP, NSW, AL, ALI, QP, QA, RW, QTOT, PR,

4WCR, ALPHA, BETA, IDM

IF (NTAPE.EQ. 1) GO TO 590

$\operatorname{READ}(1, *)$ KODE $, Q, P, P 1, X, Y, K X, S A N G, C A N G, N P, N S P$,

1KODES, WIDTH, BTP, NCOL, NSOUR, PW, TPOT, NRB, NRT, W, RDF , MTR, CONS1, CONS2,

$2 C 1, C 2$, SS, POR, IA, ITER, DT, TIME, DT1, KAT, INTEG , NE , NB,

3NPT, NPT1, NPB, NPB1, NBW, LW, NEP, NSW, AL, AL1, QP, QA, RW, QTOT, PR,

4WCR, ALPHA, BETA, IDM

REWIND 1

WRITE $(1, *)$ NUMNP, MBAND, NUMEL, NUMMAT, MAXSP, NDIM, NSEEP , NUMDP,

INUMEP, NPLNT, NDIMP, MXCOL, MXNOD

WRITE $(1, *)$ KODE $, Q, P, P I, X, Y, K X$, SANG , CANG , NP, NSP,

1KODES, WIDTH, BTP , NCOL, NSOUR, PW , TPOT, NRB, NRT, W, RDF , MTR, CONS1, CONS2,

$2 \mathrm{C1}, \mathrm{C2}$, SS, POR, LA, ITER, DT, TIME , DT1 , KAT, INTEG, NE , NB,

3NPT, NPT1, NPB, NPB1, NBW, LW, NEP, NSW, AL, ALI, QP, QA, RW, QTOT, PR,

4WCR, ALPHA, BETA, IDM

590 READ $(15,600)$ MAXIT, DD, DTMAX, DTMIN, DMUL, TMAX, TOL, QP, ALFA, INPR

IF (ALFA . LE. 0.) ALFA $=.8$

600 FORMAT (I5, 8E10.3, I5)

IF (DD .GT. O.) $\quad \mathrm{DT}=\mathrm{DD}$

IF (DD .LE. 0.) DT=DMUL*DT

IF (NUMEP . LT. 1) GO TO 620

READ $(15,91)$ EI, PL, BTPI

$I=0$

DO $610 \mathrm{~N}=1$, NUMNP

IF (KODE (N) .EQ. 4) $\operatorname{KODE}(\mathrm{N})=-4$

IF (KODE $(N)$.NE. -4$)$ GO TO 610

$I=I+1$

$\operatorname{BTP}(I)=\operatorname{BTP}(I) * B T P I$

IF (BTP(I) .GT. 1.) BTP (I) $=1$.

610 CONT: NUE

$Q(N)=B T P(I) * E I * W I D T H(I)$

620 IF (NPLNT.LT. 1) GO TO 670

DO $660 \mathrm{~J}=1$, NPINT

NSJ $=$ NSOUR $(J)$

NSJ $1=N S J+1$

VALUE $=$ TPOT $(\mathrm{J})$

READ $(15,630)$ NCJ, TPOT (J)

630 FORMAT (I5, E10.3)

IF (NCJ.IT. 1) GO TO 650

$\operatorname{READ}(15,91) \quad(\operatorname{RDF}(N, J), N=1, N S J 1)$

91 FORMAT (8E10.3)

WRITE $(6,640) \mathrm{J},(\operatorname{RDF}(\mathrm{N}, \mathrm{J}), \mathrm{N}=1, \mathrm{NSJ} 1)$

640 FORMAT (41H NEW ROOT DISTRIBUTION FUNCTION FOR PLANT, I3,27H, STAR 1TING AT BOTTOM NODE -// 10(E13.5))

650 IF (ABS (VALUE-TPOT(J)).LE. 1.OE-15) GO TO 660

CALL TRANSP $(Q, P, P I, T, C R, Y, N C O L, N S O U R, P W, T P O T$,

INRB, NRT, $W, P R, R D F, M T R, S A V E, N U M N P$, NUMMAT , NPLNT , NDIMP,

2MXCOL, MXNOD, J)

660 CONTIIIUE

670 IF (NSEEP .LT. 1) GO TO 680 


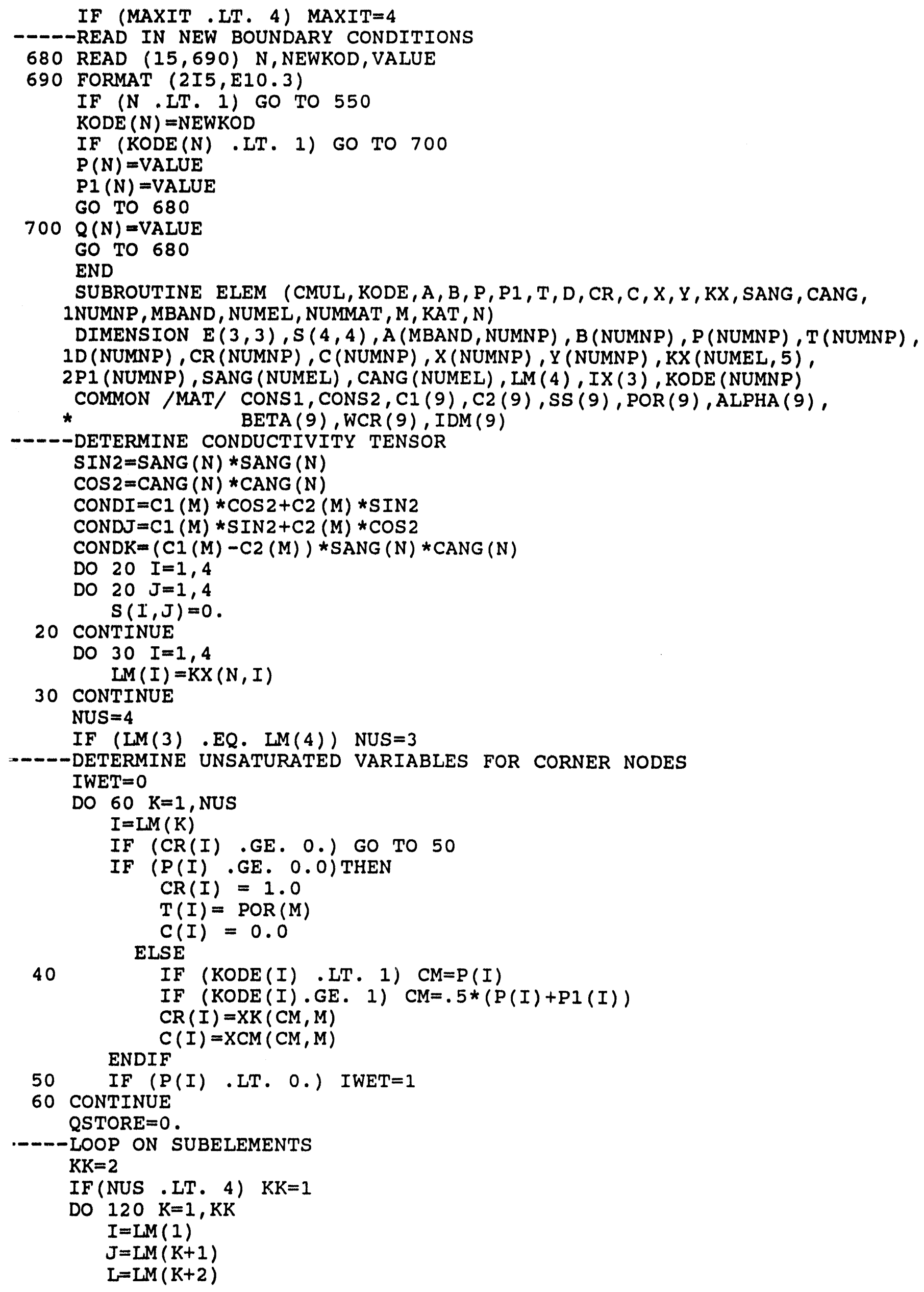




$$
\begin{aligned}
& C I=X(I)-X(J) \\
& C J=X(I)-X(I) \\
& C K=X(J)-X(I) \\
& B I=Y(J)-Y(I) \\
& B J=Y(I)-Y(I) \\
& B K=Y(I)-Y(J) \\
& X M U I=I .
\end{aligned}
$$

IF (KAT .NE. 1) GO TO 80

$X M U L=(X(I)+X(J)+X(L)) / 3$.

$80 \quad D E L 2=C K * B J-C J * B K$ $\operatorname{OPEN}(8$, flie='areas.dat', status=' unknown')

write $\left(8, '(10 x, 15,3 x, \text { el5.3 })^{\prime}\right)$ n, del 2

$C M=(C R(I)+C R(J)+C R(L)) / 3$.

$\mathrm{COMM}=.5 * \mathrm{XMUL} * \mathrm{CM} / \mathrm{DEL} 2$

QSTORE $=.5 * D E L 2 * X M U L$

$$
\text { IF (KAT . GE. 1) THEN }
$$

$A A=.5 * C M * X M U L$

$B(I)=B(I)+A A *(C O N D K * B I+C O N D J * C I)$

$B(J)=B(J)+A A *(C O N D K * B J+C O N D J * C J)$

ENDIF

$B(L)=B(L)+A A *(C O N D K * B K+C O N D J * C K)$

$E(1,1)=C O N D I * B I * B I+2 . * C O N D K * B I * C I+C O N D J * C I * C I$

$E(1,2)=C O N D I * B I * B J+C O N D K *(B I * C J+C I * B J)+C O N D J * C I * C J$

$E(1,3)=C O N D I * B I * B K+C O N D K *(B I * C K+C I * B K)+C O N D J * C I * C K$

$E(2,1)=E(1,2)$

$E(2,2)=C O N D I * B J * B J+2, * C O N D K * B J * C J+C O N D J * C J * C J$

$E(2,3)=C O N D I * B J * B K+C O N D K *(B J * C K+B K * C J)+C O N D J * C J * C K$

$E(3,1)=E(1,3)$

$E(3,2)=E(2,3)$

$E(3,3)=C O N D I * B K * B K+2 . * C O N D K * B K * C K+C O N D J * C K * C K$

$\operatorname{IX}(1)=1$

$\operatorname{IX}(2)=\mathrm{K}+1$

$\operatorname{IX}(3)=\mathrm{K}+2$

DO $110 \quad I=1,3$

$I I=I X(I)$

$I J=L M(I I)$

$B B=0$.

IF (IWET .EQ . 0) $B B=T(I J) \star C M U L$

$A A=C(I J)+B B$

DO $100 \mathrm{~J}=1,3$

$J J=I X(J)$

$J I=L M(J J)$

$\mathrm{BB}=0$.

IF (IWET . EQ. 0) $B B=T(J I) * C M U L$

$A A=A A+C(J I)+B B$

$S(I I, J J)=S(I I, J J)+E(I, J) * C O M M$

$D(I J)=D(I J)+A A * Q S T O R E / 12$.

120 CONTINUE

----ADD ELEMENT CONTRIBUTION TO A MATRIX

$$
\text { DO } 140 \quad \mathrm{~L}=1,4
$$

$I=L M(L)$

DO $130 \quad K=1,4$

$J=I M(K)-I+1$

IF (J .LT. 1) GO TO 130

130 CONTINUE

$A(J, I)=A(J, I)+S(L, K)$

140 CONTINUE

RETURN 


\section{END}

SUBROUTINE RESET (KODE, A, B, Q, P, P1, T, D, CR, $C, X, Y, K X, S A N G, C A N G$,

1 NUMNP, MBAND, NUMEL, NUMMAT, M, KAT, IA , DT, DT1, ITER, INTEG)

DIMENSION A (MBAND, NUMNP), B (NUMNP), Q (NUMNP), P (NUMNP), P1 (NUMNP), $1 T$ (NUMNP) , D (NUMNP) , CR (NUMNP) , C (NUMNP) , X (NUMNP) , Y (NUMNP) ,

2 KX (NUMEL , 5), SANG (NUMEL) , CANG (NUMEL), KODE (NUMNP)

COMMON /MAT/ CONS1, CONS2, C1 (9), C2 (9), SS(9), POR(9), ALPHA (9),

*

$\operatorname{BETA}(9), W C R(9), \operatorname{IDM}(9)$

IF (LA .GT. 1) DTT $=.5 * D T / D T 1$

INITIALIZATION AND EXTRAPOLATION OF P VALUES

DO $40 \quad I=1$, NUMNP

$B(I)=0$.

$D(I)=0$.

IF(ITER.GT.0) GO TO 10

IF (LA .LE.1) PP $=P I$ (I)

IF (LA .GT.1) PP $=P(I)+D T T *(P(I)-P I(I))$

$P 1(I)=P(I)$

IF (KODE (I) .LT. 1) $P(I)=P P$

GO TO 20

$10 \mathrm{PP}=.5 *(\mathrm{P}(\mathrm{I})+\mathrm{P} 1(\mathrm{I}))$

IF (KODE (I) .IT. 1) $P(I)=P P$

20 DO $30 \mathrm{~J}=1$, MBAND

$A(J, I)=0$.

30 CONTINUE

40 CONTINUE

DO $70 M=1$, NUMMAT

CMUL=CONS 1 *SS (M) / POR (M)

DO $50 \quad I=1$, NUMNP

$$
C R(I)=-1 \text {. }
$$

50 CONTINUE

DO $60 \mathrm{~N}=1$, NUMEL

IF $(K X(N, 5) . N E . M)$ GO TO 60
CALL ELEM (CMUL, KODE, A, B, P, P1, T, D, CR, C, X, Y, KX, SANG, CANG,

\section{CONTINUE}

NUMNP, MBAND, NUMEL, NUMMAT, $M, K A T, N$ )

70 CONTINUE

REWIND 2

WRITE (2) A, B

COMPLETE CONSTRUCTION OF RHS VECTOR AND FORM EFFECTIVE MATRIX

$\mathrm{PP}=2$.

IF (IA .EQ. 1 .OR. INTEG .EQ. 1) $P P=1$.

DO $110 \quad I=1$, NUMNP

$B(I)=P P *(C O N S 2 * Q(I)-B(I)+D(I) * P 1(I) / D T)$

IF (PP .EQ. 1.) GO TO 100

DO $90 \mathrm{~J}=1$, MBAND

$K=I+J-1$

IF (K . GT. NUMNP) GO TO 80

$80 \mathrm{~K}=\mathrm{I}-\mathrm{J}+\mathrm{I}$

$B(I)=B(I)-A(J, I) * P I(K)$

IF (J .EQ. 1 .OR. K . LT. 1) GO TO 90

$B(I)=B(I)-A(J, K) * P I(K)$

90 CONTINUE

$100 A(1, I)=A(1, I)+P P * D(I) / D T$

110 CONTINUE

RETURN

END

SUBROUTINE MATIN (NUMMAT)

COMMON /MAT/ CONS1, CONS2, C1 (9), C2 (9), SS (9), POR(9), ALPHA (9),

* $\operatorname{BETA}(9), \operatorname{WCR}(9), \operatorname{IDM}(9)$

CHARACTER * 13 MDL(10) 
DATA MDL/'van Genuchten ',' Exponentlal ','Gardner-Russo',' User-s

*up. $1 /$

READ $(15,10)$ CONS1, CONS2

10 FORMAT (2E10.3)

WRITE $(6,20)$ CONS1, CONS2

20 FORMAT $(/ / / 50 H$ UNITS ARE CONTROLED BY THE FOLLOWING CONSTANTS - $/ /$

$19 \mathrm{H} \mathrm{CONS1}=, \mathrm{E} 12.3,3 \mathrm{X}, 7 \mathrm{HCONS2}=\mathrm{E} 12.3 / / / / 9 \mathrm{H}$ MATERIAL, 7X, 2HK1, 13X,

2 2HK2 , 10X, 8HPOROSITY, 10X, 2HSS, 12X, 3HRWC, 12X, 5HALPHA, 11X, 4HBETA,

3 11X, 6HMODEL /)

DO $50 \quad M=1$, NUMMAT

1

READ $(15,30) C 1(M), C 2(M), \operatorname{POR}(M), S S(M), W C R(M), A L P H A(M), \operatorname{BETA}(M)$

30 FORMAT (7E10.3, I5)

WRITE $(6,40) M, C 1(M), C 2(M), \operatorname{POR}(M), S S(M)$, WCR $(M), A L P H A(M), B E T A(M)$,

IMDL (IDM (M))

40 FORMAT (I6, E17.5, 6E15.5, 4X, A13)

50 CONTINUE

RETURN

END

SUBROUTINE NPIN (KODE, $Q, P, P 1, X, Y, W I D T H, N U M D P, N U M N P, I N I T, N E R R, B T P I$, 1 EI)

DIMENSION KODE (NUMNP) , $Q$ (NUMNP) , PI (NUMNP) , X(NUMNP) , Y (NUMNP) ,

$1 P$ (NUMNP) , WIDTH (NUMDP)

NERR $=0$

WRITE $(6,10)$

10 FORMAT $(/ / / / 24 \mathrm{H}$ NODAL POINT INFORMATION $/ / 10 \mathrm{H}$ NODE NO, ,6X, 4HKODE,

$17 X, 3 H X, R, 12 X, 3 H Y, Z, 11 X, 5 H . P S I ., 12 X, 1 H Q /)$

$N P R=0$

$L=0$

$20 \mathrm{~L}-\mathrm{L}+1$

$30 \operatorname{READ}(15,40) \quad N, \operatorname{KODE}(N), X(N), Y(N), P I(N), Q(N)$

40 FORMAT $(2 I 5,4$ E1O.3)

$P I(N)=P \perp(N)-I N I T * Y(N)$

IF $(N-L) \quad 50,90,70$

50 WRITE $(6,60) \mathrm{N}$

60 FORMAT (2OH ERROR IN NPIN AT $N=$, I5)

$N E R R=1$

RETURN

70 DENO $=\mathrm{N}-\mathrm{L}+1$

$D X=(X(N)-X(N P R)) / D E N O$

$D X=(Y(N)-Y(N P R)) / D E N O$

$D P=(P I(N)-P I(N P R)) / D E N O$

$80 X(L)=X(L-1)+D X$

$Y(L)=Y(L-1)+D Y$

$\mathrm{PI}(L)=\mathrm{PI}(L-1)+D P$

$\operatorname{KODE}(L)=\operatorname{KODE}(L-1)$

$Q(L)=Q(L-1)$

$\mathrm{L}=\mathrm{L}+1$

IF (L.LT. N) GO TO 80

$90 \quad N P R=N$

IF ( $L$.LT. NUMNP) GO TO 20

$I=0$

DO $110 \mathrm{~N}=1$, NUMNP

WRITE $(6,100) N, \operatorname{KODE}(N), X(N), Y(N), P I(N), Q(N)$

3.00 FORMAT $(2 I 10,4$ E15.6)

$P(N)=P I(N)$

IF (KODE $(N)$.NE. -4$)$ GO TO 110

$I=I+1$

$Q(N)=B T P I * E I * W I D T H(I)$ 


\section{CONTINUE}

RETURN

END

SUBROUTINE MAFILI (KX, SANG, CANG, NUMEL)

DIMENSION KX(NUMEL, 5), SANG (NUMEL), CANG (NUMEL)

NUM $=0$

WRITE $(6,10)$

10 FORMAT (////2OH ELEMENT INFORMATION//55H ELEMENT C O R N E R N

$10 \mathrm{DE} S$ MATERIAL ANGLE/)

DO $60 \mathrm{~N}=1$, NUMEL

IF (NUM-N) $20,60,40$

20 READ $(15,30)$ NUM, (KX (NUM, I), I=1,5), SANG (NUM)

30 FORMAT (6I5, E10.3)

IF $(K X(N U M, 4)$.EQ. 0$) \quad K X(N U M, 4)=K X(N U M, 3)$

IF (NUM .EQ. N) GO TO 60

40 DO $50 I=1,4$

$K X(N, I)=K X(N-1, I)+1$

50 CONTINUE

$K X(N, 5)=K X(N-1,5)$

SANG $(N)=$ SANG $(N-1)$

60 CONTINUE

$A A=3.141592654 / 180$.

DO $80 \mathrm{~N}=1$, NUMEL

$B B=A A * \operatorname{SANG}(N)$

WRITE $(6,70) N, \operatorname{KX}(N, 1), \operatorname{KX}(N, 2), \operatorname{KX}(N, 3), \operatorname{KX}(N, 4), \operatorname{KX}(N, 5)$, SANG $(N)$

70 FORMAT (I6, I9, 3I $6, I 10$, E14.3)

71 FORMAT $(1,6$ I5, E10.3)

$C C=\operatorname{SIN}(B B)$

$\operatorname{SANG}(N)=C C$

$C C=\cos (B B)$

CANG $(N)=C C$

80 CONTINUE

RETURN

END

SUBROUTINE CONSTP ( $A, B, K O D E, P, N U M N P, M B A N D)$

DIMENSION A (MBAND, NUMNP) , B (NUMNP), KODE (NUMNP) , P (NUMNP)

DO $70 \mathrm{~N}=1$, NUMNP

IF (KODE (N) .IT. 1) GO TO 70

10 DO $60 \quad M=2$, MBAND

$\mathrm{K}=\mathrm{N}-\mathrm{M}+\mathrm{I}$

IF (K) $30,30,20$

$20 \quad B(K)=B(K)-A(M, K) * P(N)$

$A(M, K)=0$.

$30 \quad L=N+M-1$

IF (NUMNP-L) $50,40,40$

$40 B(L)=B(L)-A(M, N) \star P(N)$

$50 A(M, N)=0$.

60 CONTINUE

$A(1, N)=1$.

$B(N)=P(N)$

70 CONTINUE

RETURN

EIND

SUBROUTINE FIXQ (A, B, KODE, $Q, P, P 1, D$, NUMNP, MBAND, DT, LA, INTEG)

DIMENSION A (MBAND, NUMNP) , B (NUMNP) , KODE (NUMNP) , $Q$ (NUMNP) , P (NUMNP),

$1 P 1$ (NUMNP) , D (NUMNP)

COMMON /MAT/ CONS1, CONS2, C1 (9), C2 (9), SS (9), POR (9), ALPHA (9),

* $\operatorname{BETA}(9), \operatorname{WCR}(9), \operatorname{IDM}(9)$

REWIND 2

READ (2) A, B 


\section{PPP=1.}

$P P=2$.

IF (LA .NE. 1 .AND. INTEG .NE. 1) GO TO 10

\section{PPP $=0$.}

\section{$P P=1$.}

10 DO $40 \mathrm{~N}=1$, NUMNP

IF (KODE $(N)$. LT. I) GO TO 40

$Q N=P P *(B(N)+D(N) *(P(N)-P 1(N)) / D T)+A(1, N) *(P(N)+P 1(N) * P P P)$

DO $30 \mathrm{~J}=2$, MBAND

$\mathrm{K}=\mathrm{N}-\mathrm{J}+1$

IF (K.LT. 1) GO TO 20

$20 \mathrm{~K}=\mathrm{N}+\mathrm{J}-\mathrm{I}$

$$
Q N=Q N+A(J, K) *(P(K)+P I(K) * P P P)
$$

IF (K .GT. NUMNP) GO TO 30

$Q N=Q N+A(J, N) \star(P(K)+P I(K) \star P P P)$

30 CONTINUE

$Q N=Q N /($ CONS2 $* P P)$

$Q(N)=Q N$

40 CONTINUE

\section{RETURN}

\section{END}

SUBROUTINE MOIST ( $P, P 1, T, T 1, K X, N U M N P, N U M E L$, NUMMAT)

DIMENSION P (NUMNP), PI (NUMNP), T (NUMNP), TI (NUMNP) , KX (NUMEL, 5 ) ,

$1 \operatorname{NN}(8), \operatorname{TT}(8)$

COMMON/MAT/ CONS1, CONS2, C1 (9), C2 (9), SS (9), POR (9), ALPHA (9),

\section{- BETA (9), WCR(9), IDM(9)}

DO $130 \quad M=1$, NUMMAT

DO $10 \quad I=1$, NUMNP

$$
T(I)=-1 \text {. }
$$

10

$$
\text { CONTINUE }
$$

$$
A W C=P O R(M)-W C R(M)
$$

DO $60 \quad N=1$, NUMEL

IF $(K X(N, 5)$.NE. $M)$ GO TO 60

NUS $=4$

IF $(\mathrm{KX}(\mathrm{N}, 3) \quad . \mathrm{QQ}, \mathrm{KX}(\mathrm{N}, 4)) \quad \mathrm{NUS}=3$

DO $50 \mathrm{~J}=1$, NUS

$I=K X(N, J)$

IF (T(I) .GT. O.) GO TO 50

IF (PI(I) .LT. 0.) GO TO 20

$T 1(I)=\operatorname{POR}(M)$

GO TO 30

20

$T 1(I)=W C R(M)+A W C * S E(P I(I), M)$

\section{CONTINUE}

$$
T(I)=W C R(M)+A W C * S E(P(I), M)
$$

\section{WRITE $(6,70) \quad M$}

70 FORMAT ( $/ /$ ' MOISTURE CONTENT AT UNSATURATED NODES CORRESPONDING TO

1 MATERIAL', I3/)

$$
J=0
$$

$N=0$

80

DO $90 \mathrm{~K}=1,6$

$$
N N(K)=0
$$

$$
\mathrm{TT}(\mathrm{K})=0 \text {. }
$$

$100 \quad \mathrm{~N}=\mathrm{N}+1$

IF (N .GT. NUMNP) GO TO 110

IF $(\mathrm{T}(\mathrm{N}) \cdot \mathrm{EQ}, \operatorname{POR}(\mathrm{M})$.OR. $\mathrm{T}(\mathrm{N})$.LT. 0.) GO TO 100 


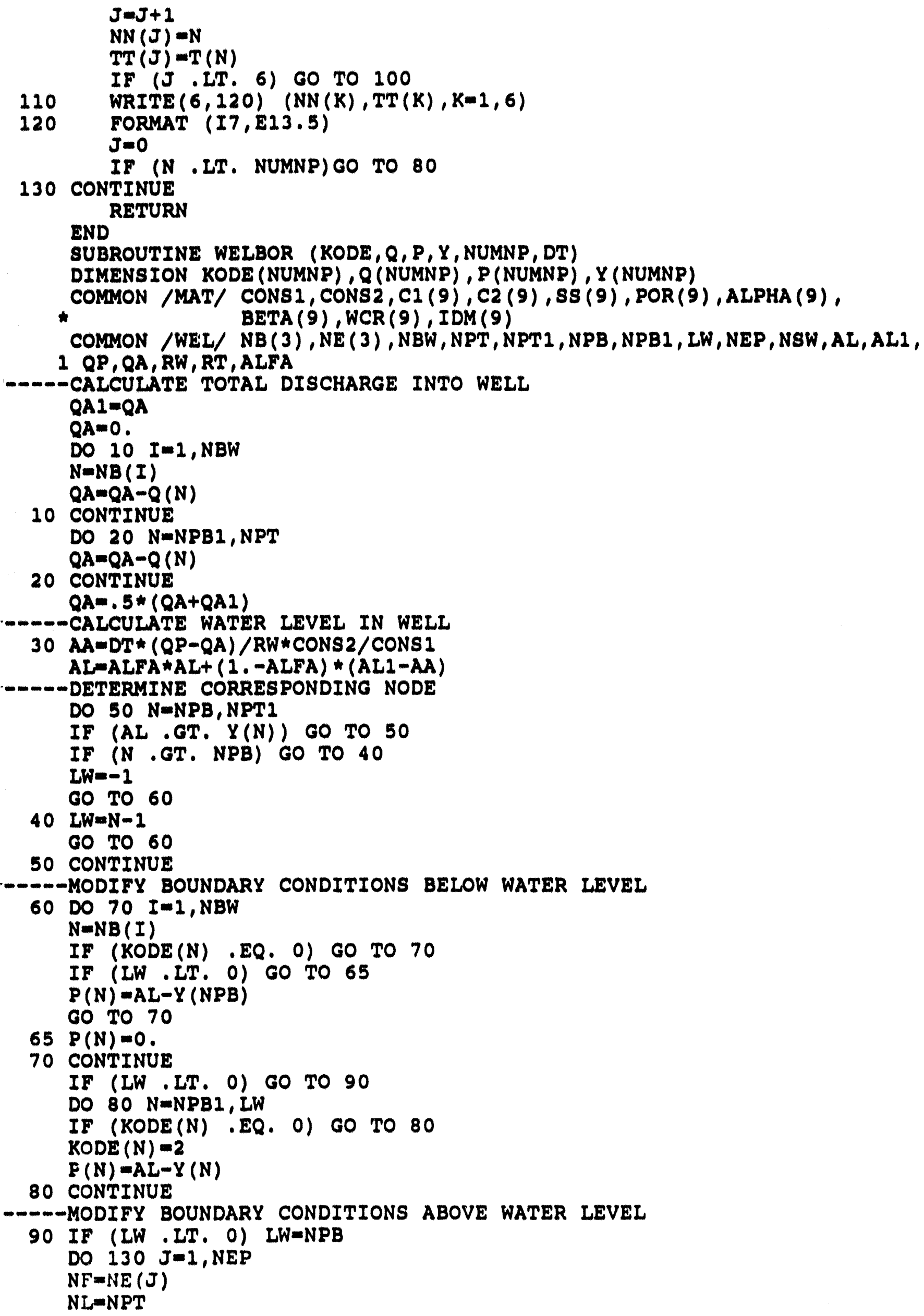


IF (J . LT. NEP) NLENE $(J+1)-1$

ICHECK $=0$

DO $120 \quad N=N F, N L$

IF (N.LE. LW) GO TO 120

IF (KODE(N) .NE. -2) GO TO 100

IF $(P(N)$. LT. O.) ICHECK=1

IF (ICHECK .GT. O) GO TO 120

KODE $(N)=2$

$95 P(N)=0$.

Go TO 120

100 IF (KODE (N) .NE. 2) GO TO 120

IF (ICHECK .OT, 0) GO TO 110

IF $(Q(N), G E .0$.$) GO TO 110$

CO TO 95

$110 \operatorname{KODE}(N)=-2$

$Q(N)=0$.

ICHECK:1

120 CONTINUE

130 CONTINUE

140 RETURN

END

SUBROUTINE PRINTO (Q,P, $Y, N U M N P, K A T)$

DIMENSION Q (NUMNP) , P (NUMNP), Y (NUMNP), NN (3), PP (3), HH (3),QQ (3)

WRITE $(6,10)$

10 FORMAT $(/ / / / 1 H 0,3(43 H$ NODE HEAD PRESS HEAD DISCHARGE)

$1 / /)$

$J=0$

$N=0$

$20 N=N+1$

$J=J+1$

IF (N . GT. NUMNP) 60 TO 30

$N N(J)=N$

$P P(J)=P(N)$

$H H(J)=P P(J)$

IF (KAT .GT. O) HH(J) $=H H(J)+Y(N)$

$Q Q(J)=Q(N)$

30 GN TO 40

$P P(J)=0$.

HH (J) $=0$.

$Q Q(J)=0$.

40 IF (J .LT. 3) 60 TO 20

WRITE $(6,50) \quad(N N(J), H H(J), P P(J), Q Q(J), J=1,3)$

50 FORMAT $(1 X, 3(I 4,3 E 13.5))$

$J=0$

IF (N. LT. NUMNP) GO TO 20

RETURN

END

SUBROUTINE SOLVE (A,B, NUMNP, MBAND)

DIMENSION A (MBAND, NUMNP) , B (NUMNP)

REDUCTION

DO $30 \mathrm{~N}=1$, NUMNP

DO $20 \quad M=2$, MBAND

IF $(A(M, N)$.EQ.0.) GO TO 20

$C=A(M, N) / A(1, N)$

$I=N+M-I$

IF (I . GT. NUMNP) GO TO 20

$J=0$

DO $10 K=M$, MBAND

$J=J+1$ 
$10 \operatorname{IF}(A(K, N)$.NE. O.) A(J,I) $=A(J, I)-C \pitchfork A(K, N)$

$A(M, N)=C$

20 CONTINUE

$$
B(I)=B(I)-A(M, N) * B(N)
$$

$B(N)=B(N) / A(1, N)$

30 CONTINUE

\section{BACK BUBSTITUTION}

$N$ - NUNWP

40 DO $50 K=2$, MBAND

$L=N+K-1$

IF (L .OT. NUMNP) 60 TO 60

50 IF $(A(K, N)$.NE. O.) $B(N)-B(N)-A(K, N) * B(L)$

$60 N=N-1$

IF $(N . G T, 0) 60$ To 40

RETURN

END

SUBROUTINE TRANSP (Q, P, P1, T, CR, Y, NCOL, NSOUR, PW, TPOT,

INRB, NRT, $W$, PR, RDF, MTR, SAVE, NUMNP, NUMOLT, NPLNT, NDIMP,

2MXCOL, MXNOD, J)

DIMENSION Q (NUMNP), P (NUMNP), PI (NUMNP), T (NUMNP), CR (NUMNP), Y (NUMNP),

$1 N C O L$ (NDIMP) , NSOUR (NDIMP), PW (NDIMP) , TPOT (NDIMP), NRB (MXCOL, NDIMP), 2NRT (MXCOL, NDIMP) , RDF (MXNOD, NDIMP), W (MXCOL, NDIMP) , PR (MXCOL, NDIMP), 3KTR (MXNOD, NDIMP) , SAVE $(2, M X N O D)$

COMAON /MAT/ CONS1, CONS2, C1 (9), C2 (9), SS(9), POR(9), ALPHA (9),

• $\operatorname{BETA}(9), W C R(9), \operatorname{IDM}(9)$

$N C J=N \operatorname{CoL}(J)$

NSI $-N S O U R(J)$

NBJ $1-N B J-1$

DO $90 I=1, N C J$

$\operatorname{PR}(I, J)=P W(J)$

IF (TPOT (J) .GE. O.) $\operatorname{PR}(I, J)=0$.

$\operatorname{NB}=\operatorname{NRB}(I, J)$

$N T-N R T(I, J)$

$N D=(N T-N B) /(N S J-1)$

$N C=0$

$Q(N B)=0$.

PNII $.3 *(P(N B)+P I(N B))$

DO $30 N K=1$, NSJ 1

$N=N B+(N K-1) * N D$

$N 1=N+N D$

$Q(N 1)=0$.

IF (TPOT(J) .GE. O.) GO TO 30

PN=PNN

PNN=.5*(P(N1) +P1 (N1))

$\mathrm{NC}=\mathrm{NC}+1$

$\operatorname{MmMTR}(N C, J)$

IF (NC .EQ. 1) GO TO 10

10

IF (NC.GT. 1 .AND. $M . E Q \cdot \operatorname{MTR}(N C-1, J))$ GO TO 20

20

30 $C R(N)=X K(P N, M)$ $C R(N I)=X K(P N N, M)$ $C C=(Y(N I)-Y(N)) \star C 1(M)$

$C M=C C \star R D F(N C, J) * C R(N)$

SAVE $(1, N C)=C M$

CX-CC*RDF $(N C+1, J) \star C R(N 1)$

$\operatorname{SAVE}(2, N C)=C M$

CONTINUE

IF (TPOT(J) .GE. 0.0) GO TO 90

$\mathrm{NC}=\mathrm{O}$

PNN=0.5*(P(NB)+P1(NB))

DO $40 \mathrm{NK}=1$, NSJ 1 


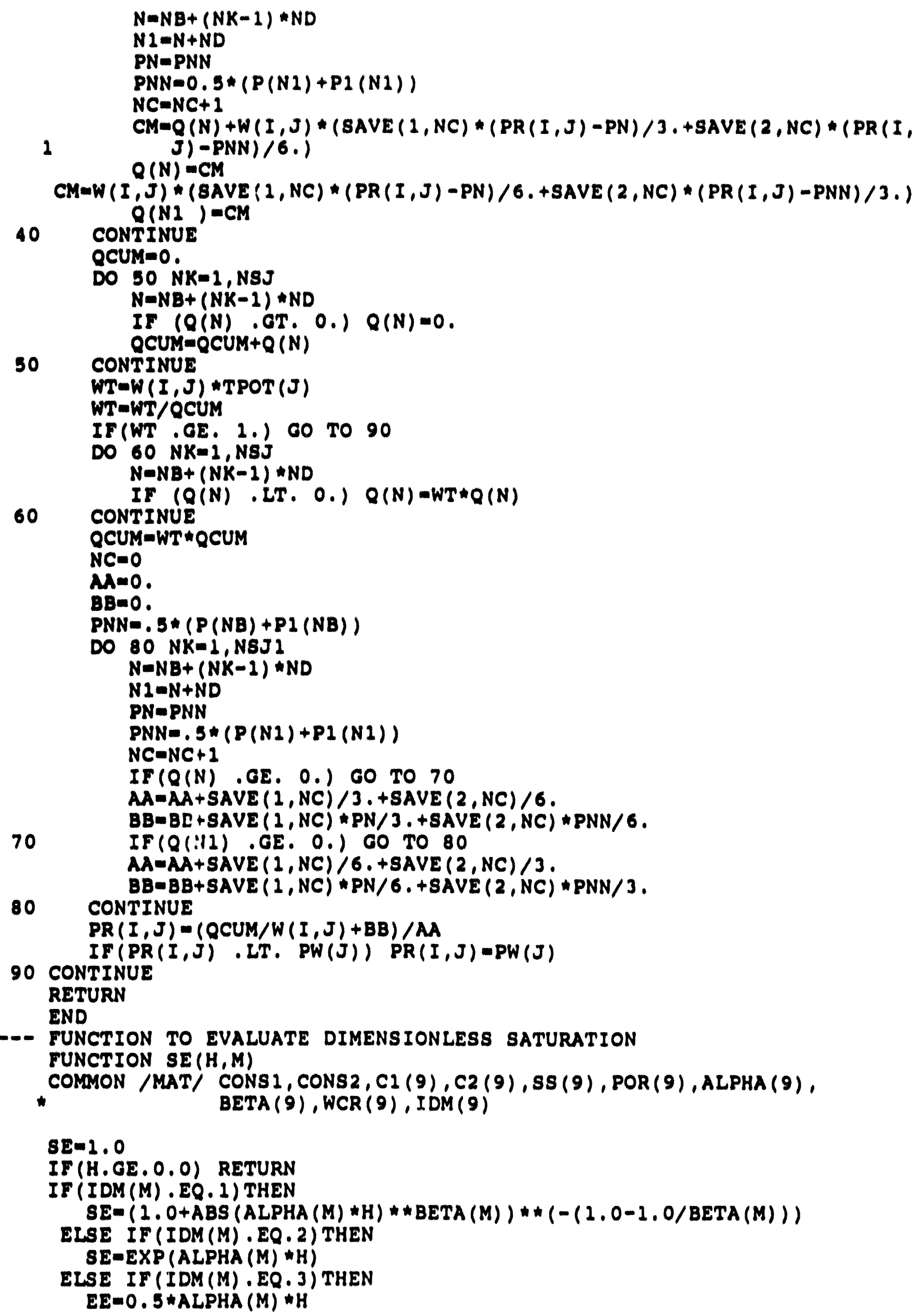




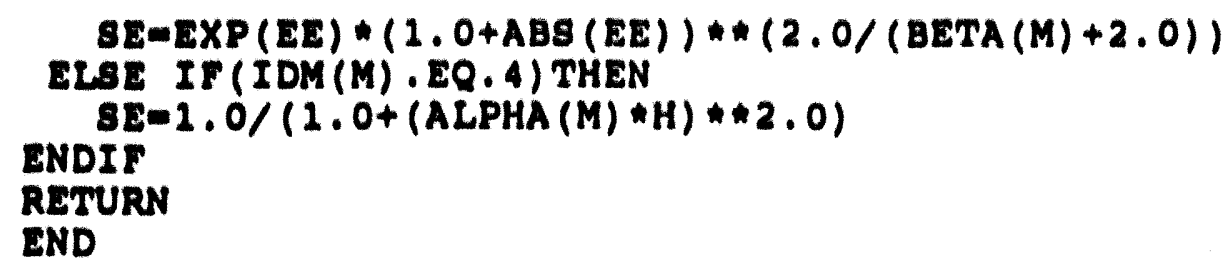

FUNCTION TO EVLAUTE RELATIVE CONDUCTIVITY

TUNCTION XK(H,M)

COMMON /MAT/ CONS1, CONS2, C1 (9), C2 (9), S8(9), POR (9), ALPHA (9),

* $\operatorname{BETA}(9), W C R(9), \operatorname{IDM}(9)$

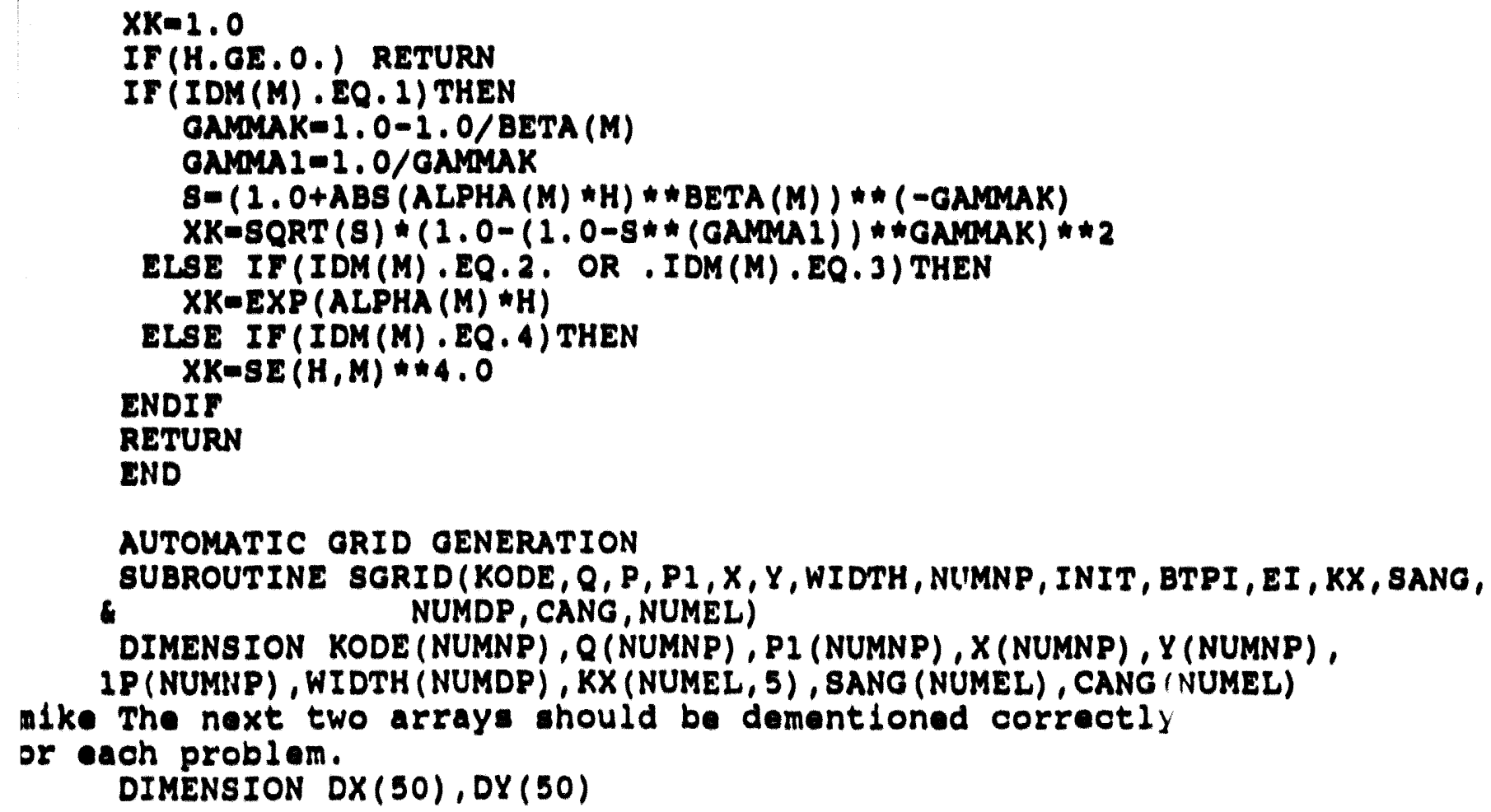


Reade number of columne and rows for grid

$\operatorname{READ}(15, *) N C, N R$

Reads Index whlch indicates if the DX and DY are constant $\operatorname{READ}(15, *)$ ICDX, ICDY

If ICDX .eq. O indlcates that DX is constant and only one value 1s needed:

If ICDX .ne. O Indlcates varying $D X$ and NC values need to be supplied.

IF (ICDX.NE. O) THEN

$$
\text { IRC - NC }
$$

ELSE

ENDIF

IRC $=1$

$\operatorname{READ}(15, *)(D X(I), I=1, \operatorname{IRC})$

IF (IRC. EQ.1) THEN

10

DO $10 \quad I=1$, NC

ENDIF

$$
D X(I)=D X(1)
$$

IF (ICDY.NE. O) THEN

IRR - NR

ELSE

ENDIF

$I R R=1$

$\operatorname{READ}(15, *)$ (DY (I), I=1, IRR)

IF (IRR. EQ.1) THEN

DO $20 I=1, N R$

20

ENDIF

$D Y(I)=D Y(1)$

Figures out which value is larger; NC or NR, to declde the direction in which the grid will be numbered, (1.e., horizontally or vertically).

IF (NC. GE. NR) THEN

CALL NODIN (NR, NC, DY, DX, $Y, X, N U M N P$ )

ELSE

ENDIF

CALL NODIN (NC, NR, DX, DY, $X, Y, N U M N P$ )

$N T N=(N C+1) *(N R+1)$

NEL - NC * NR

IF (NTN . NE. NUMNP. OR , NEL.NE. NUMEL) THEN

WRITE $(\pitchfork, 99)$

ENDIF

WRITE $(6,99)$

Reads the code, flow rate and pressure for each node

$\operatorname{READ}(15, *)$ (KODE (I), I=1, NUMNP)

$\operatorname{READ}(15, *)(Q(I), I=1$, NUMNP)

$\operatorname{READ}(15, *)(P I(I), I=1$, NUMNP)

DO 25 I 1 , NUMNP

$P I(I)=P I(I)-I N I T * Y(N)$

$P(I)=P I(I)$

25 CONTINUE

Writes the nodal information to unit 6 (unsat.out)

$\operatorname{WRITE}(6,60)$ 
$J=0$

DO $50 I=1$, NUMNP

WRITE $(6,100) I, \operatorname{KODE}(I), X(I), Y(I), P 1(I), Q(I)$

IF (KODE (I) . NE. -4) GOTO 50

$\mathrm{J}=\mathrm{J}+1$

50 CONTINUE

$Q(I)=B T P I * E I * W I D T H(J)$

Reade the materlal and the angle (degrees) between $K 11$ and the coordinate axis to be used for each element

$\operatorname{READ}(15, *)((K X(I, J), J=5,5), I=1, N U M E L)$

$\operatorname{READ}(15, *)(\operatorname{SANG}(I), I=1, N U M E L)$

Aselgne lement numbers and corresponding corner nodes

IF (NC. GE.NR) THEN

CALL ELEMI (NR, NC, KX, NUMEL)

ELSE

ENDIF

CALL ELEM2 (NC, NR, KX, NUMEL)

Writes the element information to unit 6 (unsat.out)

WRITE $(6,70)$

$M A=3.141592654 / 180$.

DO $80 \mathrm{~N}=1$, NUMEL

$B B=A A *$ SANG $(N)$

WRITE $(6,71) N, K X(N, 1), K X(N, 2), K X(N, 3), K X(N, 4), K X(N, 5), \operatorname{sANG}(N)$

$C C=\sin (B B)$

$\operatorname{SANC}(N)-\mathrm{C}$

$C C=\cos (B B)$

CANG $(N)=C$

80 CONTINUE

60 PORMAT (////24H NODAL POINT INFORMATION $/ / 10 H$ NODE NO.,6X, 4HKODE, $17 X, 3 H X, R, 12 X, 3 H Y, 2,12 X, 5 H, P S I,, 12 X, 1 H Q /)$

70 FORMAT (///2OH ELEMENT INFORMATION, //, ELEMENT C O R N R N $10 D$ E MATERIAL ANGLE'/)

71 FORMIT $(I 6, \pm 9,3$ I 6, I $10, E 14.3)$

72 FORMAT $(6: 5,210.3)$

99 FORNAT(/,"*** ERROR IN SGRID: NUMBER OF GENERATED NODES OR ELEMEN CTS IS NOT EQUAL TO SPECIFIED NUMNP OR NUMEL $* \star \star *, 1)$

100 FORMAT (2I10,4E15.6)

RETURN

END

This subroutine numbers the grid and generates node coordinates SUBFOUTINE NODIN (IFAST, ISLOW, DX1, DX2, X1, X2, NUMNP)

DIMENSION $\times 1$ (NUMNP), $\times 2$ (NUMNP)

DIMENSIUN DX1(1), DX2(1)

$N=0$

$X 2 L=0.0$

DO $30 I=1$, ISLOW +1

$X I L=0.0$

DO $25 \mathrm{~J}=1$, IFAST +1

$N=N+1$

$X_{2}(N)=X_{2} L$

$X 1(N)=X 1 L$

$X I L=X I L+D X I(J)$

CONTINUE

$\therefore 2 L=X 2 L+D X 2(I)$ 
30 CONTINUE

RE'URN

END

The following subroutines create element information

SUBROUTINE ELEM1 (IF, IS, KX, NUMEL)

DIMENSION KX(NUMEL, 5)

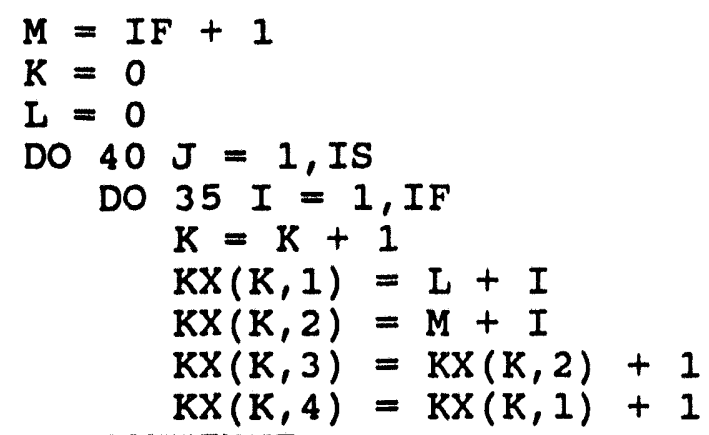

35 CONTINUE

$$
\begin{aligned}
& L=M \\
& M=I+I F+I
\end{aligned}
$$

40 CONTINUE

\section{RETURN}

END

SIIBROUTINE ELEM2 (IF, IS, KX, NUMEL)

DIMENSION KX(NUMEL, 5)

$M=I F+1$

$\mathrm{K}=0$

$\mathrm{L}=0$

DO $40 \mathrm{~J}=1$, IS

DO $35 I=1$, IF

$K=K+1$

$\mathrm{KX}(\mathrm{K}, \mathrm{I})=\mathrm{I}+\mathrm{I}$

$\mathrm{KX}(K, 2)=\mathrm{KX}(K, 1)+1$

$\mathrm{KX}(\mathrm{K}, 4)=M+I$

35 CONTINUE

$$
\mathrm{KX}(\mathrm{K}, 3)=\mathrm{KX}(\mathrm{K}, 4)+1
$$

$$
\mathrm{L}=\mathrm{M}
$$$$
M=L+I F+1
$$

40 CONTINUE

RETURN

END 
